\author{
UNIVERSIDADE DE SÃO PAULO \\ ESCOLA DE ENGENHARIA DE SÃO CARLOS \\ DEPARTAMENTO DE ENGENHARIA DE PRODUÇÃO
}

VITOR EDUARDO BATTISSACCO

\title{
MOTIVAÇÕES, BARREIRAS E FATORES CRÍTICOS DE SUCESSO PARA IMPLEMENTAÇÃO DO DDMRP: UM ESTUDO EXPLORATÓRIO PELO MÉTODO FUZZY DELPHI
}

SÃO CARLOS - SP 



\title{
MOTIVAÇÕES, BARREIRAS E FATORES CRÍTICOS DE SUCESSO PARA IMPLEMENTAÇÃO DO DDMRP: UM ESTUDO EXPLORATÓRIO PELO MÉTODO FUZZY DELPHI
}

\author{
Versão Corrigida
}

\begin{abstract}
Dissertação apresentada ao Programa de PósGraduação em Engenharia de Produção da Escola de Engenharia de São Carlos da Universidade de São Paulo como parte dos requisitos para a obtenção do Título de Mestre em Engenharia de Produção.

Área de Concentração: Processos e Gestão de Operações

Orientador: Prof. Dr. Kleber Francisco Espôsto
\end{abstract}

São Carlos - SP 


\begin{abstract}
AUTORIZO A REPRODUÇÃO TOTAL OU PARCIAL DESTE TRABALHO, POR QUALQUER MEIO CONVENCIONAL OU ELETRÔNICO, PARA FINS DE ESTUDO E PESQUISA, DESDE QUE CITADA A FONTE.
\end{abstract}

Ficha catalográfica elaborada pela Biblioteca Prof. Dr. Sérgio Rodrigues Fontes da EESC/USP com os dados inseridos pelo(a) autor(a).

Battissacco, Vitor Eduardo
Motivações, barreiras e fatores críticos de
sucesso para implementação do DDMRP um estudo
exploratório pelo método Fuzzy Delphi / Vitor Eduardo
Battissacco; orientador Kleber Francisco Espôsto. São
Carlos, 2021.
Dissertação (Mestrado) - Programa de
Pós-Graduação em Engenharia de Produção e Área de
Concentração em Processos e Gestão de Operações --
Escola de Engenharia de São Carlos da Universidade de
São Paulo, 2021.
1. DDMRP. 2. cadeias de suprimentos. 3. demand
driven. 4. fuzzy delphi. 5. fatores críticos de
sucesso. I. Título.

Eduardo Graziosi Silva - CRB - 8/8907 


\section{FOLHA DE JULGAMENTO}

Candidato: Engenheiro VITOR EDUARDO BATIISSACCO.

Título da dissertação: "Motivações, barreiras e fatores críticos de sucesso para implementação do DDMRP: um estudo exploratório pelo método fuzzy Delphi".

Data da defesa: $25 / 10 / 2021$

Comissão Julgadora

Prof. Dr. Kleber Francisco Espôsto

(Orientador)

(Escola de Engenharia de São Carlos/EESC-USP)

Prof. Dr. Gilberto Miller Devós Ganga

(Universidade Federal de São Carlos/UFSCar)

Prof. Dr. Moacir Godinho Filho
Aprovado

Resultado

Aprovado

Aprovade

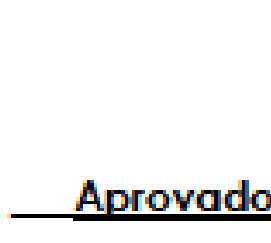

(Universidade Federal de São Carlos/UFSCar) 

Dedicatória

À minha família. 



\section{Agradecimentos}

Primeiramente gostaria de agradecer à minha família, pai, mãe e irmã pelo apoio e incentivo à conclusão deste trabalho.

Agradeço ao meu orientador Prof. Kleber Francisco Espôsto pela contribuição, apoio e dedicação na construção desta pesquisa.

Agradeço aos professores Gilberto Miller Devós Ganga e Moacir Godinho Filho pelas sugestões e contribuições durante o exame de qualificação e defesa desta dissertação.

Agradeço aos professores Fábio Müller Guerrini e Antonio Freitas Rentes pelo acompanhamento durante o estágio no Programa de Aperfeiçoamento de Ensino - PAE.

Agradeço a todos que responderam à pesquisa, sendo de grande importância para o resultado final.

Agradeço aos funcionários do departamento de Engenharia de Produção da EESC-USP pelas ajudas prestadas durante a minha trajetória acadêmica.

Agradeço à Universidade de São Paulo pela oportunidade de estudo e pesquisa.

Agradeço a Deus pela oportunidade e força.

Por fim, agradeço a Fundação Coordenação de Aperfeiçoamento de Pessoal de Nível Superior - CAPES pelo financiamento desta pesquisa. 



\section{Resumo}

BATTISSACCO, V. E. Motivações, barreiras e fatores críticos de sucesso para implementação do DDMRP: um estudo exploratório pelo método Fuzzy Delphi. 2021. Dissertação (Mestrado em Engenharia de Produção) - Escola de Engenharia de São Carlos, Universidade de São Paulo, São Carlos, 2021.

No atual contexto, as empresas estão submetidas a pressões e incertezas, dificultando o planejamento e controle de produção. Nesse ambiente foi desenvolvido o DDMRP, um método para gestão da produção que visa substituir a lógica de produção baseada em previsões de vendas do MRP por uma lógica de seguir a demanda real. Com relatos positivos sobre esse novo método, cresce o número de novas organizações interessadas em implantálo, porém, poucos trabalhos acadêmico-científicos exploraram esse tema e, menos ainda, as questões relacionadas à sua implementação. Dessa forma, essa dissertação de mestrado utiliza a metodologia Fuzzy Delphi para identificar as motivações, barreiras e fatores críticos de sucesso para a implementação do DDMRP. Para isso, foi feita uma pesquisa bibliográfica a fim de contextualizar o ambiente de desenvolvimento do DDMRP, identificar fatores de implementação de outros métodos de planejamento e controle de produção e apresentar o DDMRP. Foi construído um questionário para a condução de uma survey com especialistas pelo método Fuzzy Delphi. Os resultados indicam que as principais motivações para implementação do DDMRP estão relacionadas a aumentar a agilidade e flexibilidade, melhorar 0 nível de serviço e reduzir e controlar melhor o nível de inventários. Não houve consenso sobre as principais barreiras, mas os resultados indicam que conflitos na mudança cultural tendem a ser as principais; os principais fatores críticos de sucesso de implementação são o apoio da alta gerência, treinamento e comunicação e engajamento, demonstrando similaridades a outros métodos de gestão, como pode ser evidenciado na revisão da literatura sobre o tema.

Palavras-chave: DDMRP, cadeias de suprimentos, demand driven, fuzzy delphi, fatores críticos de sucesso. 



\begin{abstract}
BATTISSACCO, V. E. Drivers, barriers and critical success factors for DDMRP implementation: an exploratory study using Fuzzy Delphi method. 2021. Dissertation (Master's in Production Engineering) - São Carlos School of Engineering, University of São Paulo, São Carlos, 2021.
\end{abstract}

In the present context, companies are subject to pressures and uncertainties, making production planning and control difficult. In this environment DDMRP was developed, a production management method that replaces MRP's sales forecasting production logic to follow actual demand. With positive reports about this new method, the number of new organizations interested in implementing it is growing, but few academic-scientific works have explored this theme, and even less the issues about its implementation. Thus, this master's dissertation uses Fuzzy Delphi methodology to identify drivers, barriers and critical success factors for DDMRP implementation. For this purpose, a bibliographic research was carried out in order to contextualize DDMRP development environment, to identify implementation factors of other production planning and control methods and introduce DDMRP. Then, a questionnaire was made for a survey conduction with experts using the Fuzzy Delphi method. The results indicate that the main drivers for implementing DDMRP are related to increasing agility and flexibility, improving service level and reducing or controlling inventories level. There was no consensus about main barriers, but the results indicate that conflicts in cultural change tend to be the main ones; the main implementation critical success factors are top management support, training, communication and engagement, demonstrating similarities to other management methods, as evidenced in the literature review of this topic.

Keywords: DDMRP, supply chains, demand driven, fuzzy delphi, critical success factors. 



\section{Lista de Figuras e Ilustrações}

Figura 1.1 - Etapas de estruturação da Survey. ............................ 36

Figura 1.2 - Modelo do Processo de Pesquisa. ................................ 37

Figura 2.1 - Matriz de classificação para estratégias de cadeias de

suprimentos. ................................................................. 43

Figura 3.1 - Pilares fundamentais do DDMRP. ........................... 71

Figura 3.2 - Os cinco componentes de implementação do DDMRP. ..........72 72

Figura 3.3 - Lista de componentes do produto FPD com posicionamento de

buffers do DDMRP. ....................................................... 75

Figura 3.4 - Definição das zonas do buffer do DDMRP. ...................... 76

Figura 3.5 - Zonas "Top of" do buffer DDMRP............................ 79

Figura 3.6 - Nível de inventário disponível alvo. ............................. 80

Figura 3.7 - Lista de materiais de FPA, FPB e FPC. .......................... 81

Figura 3.8 - Explosão desacoplado do DDMRP. ............................ 87

Figura 3.9 - Exemplo de geração de ordens. .............................. 87

Figura 3.10 - Tipos de Alertas do DDMRP............................... 88

Figura 4.1 - Faixa de distribuição dos valores crisp calculados - barreiras.

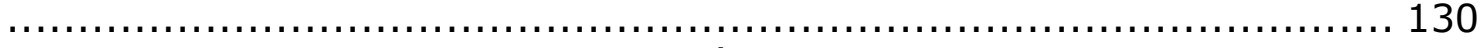

Figura 4.2 - Faixa de distribuição do índice de consenso - barreiras. ..... 131

Figura 4.3 - Faixa de distribuição dos valores crisp calculados - fatores

críticos de sucesso. .................................................... 133

Figura 4.4 - Faixa de distribuição do índice de consenso - fatores críticos de

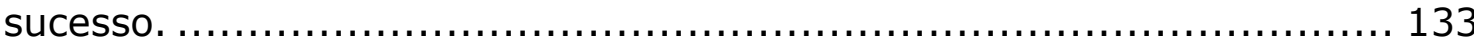





\section{Lista de Quadros e Tabelas}

Quadro 1.1 - Caracterização da pesquisa. ................................ 33

Quadro 2.1 - Definições de Agilidade em Cadeias de Suprimentos........... 45

Quadro 2.2 - Atributos das Cadeias de Suprimentos Ágeis. ................47

Quadro 2.3 - Problemas de precisão de dados e organizacionais na implementação do MRP II. ................................................. 55

Quadro 2.4 - Fatores críticos de sucesso e passos de implementação do

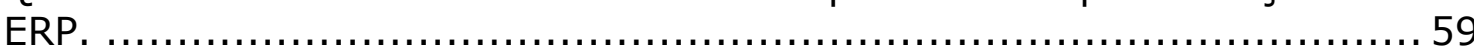

Quadro 2.5 - Motivadores e barreiras para implementação do ERP II. ..... 60 Quadro 2.6 - Fatores críticos de sucesso para implementação do ERP e ERP II. ............................................................................. 60

Quadro 3.1 - Fatores de Lead Time e Variabilidade sugeridos................. 78

Quadro 3.2 - Exemplos de dimensionamento de buffer..................... 79

Quadro 3.3 - Comparação com o posicionamento de buffers. ................ 81

Quadro 3.4 - Custo de subcomponentes comprados........................ 82

Quadro 3.5 - Análise de redução de inventário............................. 83

Quadro 3.6 - Impacto do posicionamento de buffer. ....................... 83

Quadro 4.1 - Motivações para implementação do DDMRP.................... 107

Quadro 4.2 - Barreiras para implementação do DDMRP. ..................... 108

Quadro 4.3 - Fatores críticos de sucesso para implementação do DDMRP.

Quadro 4.4 - Escala Likert de cinco termos linguísticos para números fuzzy

triangulares. ............................................................... 112

Quadro 4.5 - Tempo de experiência dos especialistas com o DDMRP...... 116

Quadro 4.6 - Tempo de experiência dos especialistas com gestão de

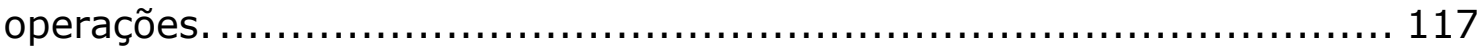

Quadro 4.7 - Setores de atuação dos especialistas. ...................... 117

Quadro 4.8 - Estratégias de resposta à demanda utilizadas................ 118

Quadro 4.9 - Sistemas utilizados antes do DDMRP...................... 118

Quadro 4.10 - Tempo em que a empresa do respondente adota o DDMRP.

Quadro 4.11 - País de atuação do especialista. ........................... 119

Tabela 3.1 - Exemplo do planejamento DDMRP para prioridades. ...........86 86

Tabela 4.1 - Análise das motivações para implementação do DDMRP..... 121

Tabela 4.2 - Análise das barreiras de implementação do DDMRP........... 122

Tabela 4.3 - Análise dos fatores críticos de sucesso para implementação do

DDMRP ..................................................................... 123 



\section{Lista de Abreviaturas e Siglas}

ADU - Average Daily Usage (Uso diário médio)

APS - Advanced Planning \& Scheduling

DDI - Demand Driven Institute

DDMRP - Demand Driven Material Requirements Planning

DLT - Decoupling Lead Time (Lead Time de Desacoplamento)

DRP - Distribution Requirements Planning

ERP - Enterprise Resource Planning

KPI - Key Performance Indicator

MOQ - Minimum Order Quantity (Quantidade mínima de encomenda)

MPS - Master Production Schedule (Plano Mestre de Produção)

MRP - Material Requirements Planning

MRP II - Manufacturing Resources Planning

NFE - Net Flow Equation (Equação de fluxo líquido).

OEE - Overall Equipment Effectiveness

OTD - On-time devilery (Entregas no prazo)

PCP - Planejamento e controle da produção

RBS - Revisão Bibliográfica Sistemática

ROI - Return on Investment

TOC - Theory of Constraints (Teoria das Restrições)

WC - Working capital (Capital de giro)

WIP - Work in process (Material em processamento) 



\section{Sumário}

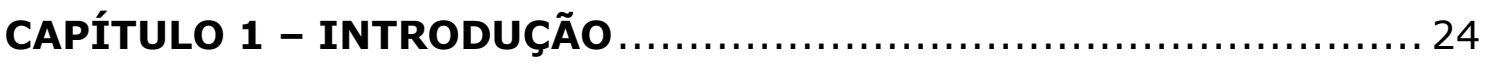

1.1 CONTEXTUALIZAÇÃO E LACUNA DE PESQUISA ........................... 24

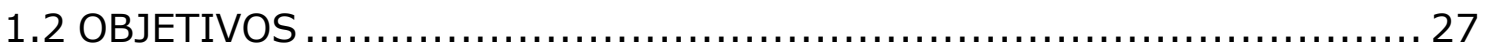

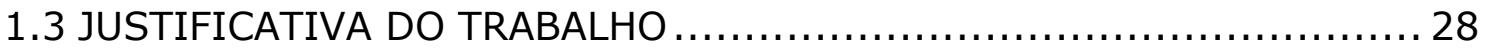

1.4 CARACTERIZAÇÃO DA PESQUISA E MÉTODO CIENTÍFICO PARA O

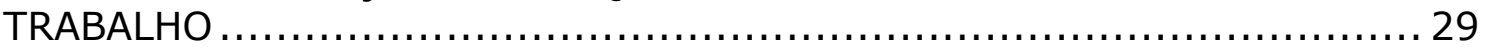

1.4.1 Abordagem da Pesquisa ............................................ 29

1.4.2 Propósito da Pesquisa ............................................... 30

1.4.3 Método de Procedimento ............................................ 31

1.4.4 Etapas e Estruturação da Survey ..................................... 33

1.5 PROCESSO DE PESQUISA E ESTRUTURA DO TRABALHO $\ldots \ldots \ldots \ldots \ldots \ldots \ldots$

CAPÍTULO 2 - REFERENCIAL TEÓRICO EXPLORATÓRIO .................. 39

2.1 CONTEXTUALIZAÇÃO DO CENÁRIO ATUAL DE GESTÃO DA CADEIA DE

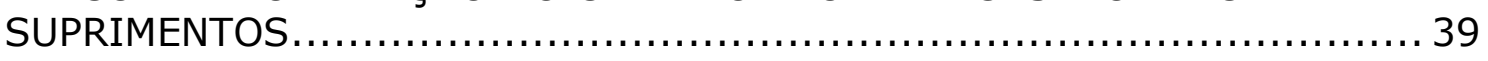

2.1.1 Definição geral do conceito de gestão da cadeia de suprimentos39

2.1.2 O ambiente atual e as cadeias de suprimentos ágeis .............. 41

2.1.3 A agilidade como estratégia em cadeias de suprimentos ......... 44

2.1.4 Demand Driven Supply Chain ...................................... 49

2.2 MOTIVAÇÕES, BARREIRAS E FATORES CRÍTIVOS DE SUCESSO PARA IMPLEMENTAÇÃO DE SISTEMAS DE PLANEJAMENTO E CONTROLE DA

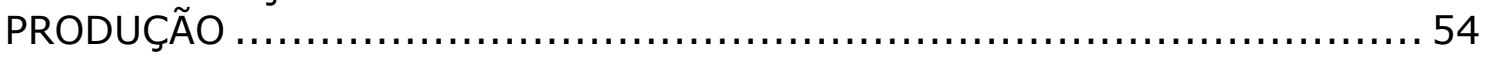

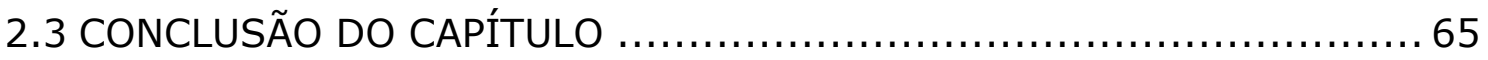

\section{CAPÍTULO 3 - INTRODUÇÃO DO DDMRP E REVISÃO BIBLIOGRÁFICA}

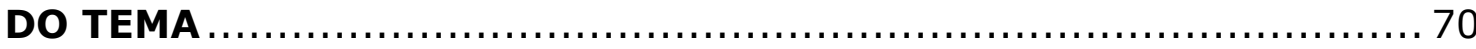

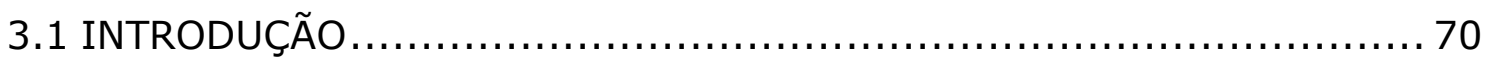

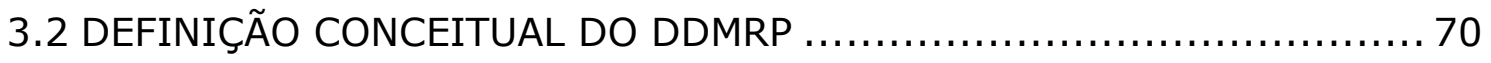

3.2.1 As Raízes e Princípios do DDMRP .................................. 70

3.2.2 Posicionamento Estratégico do Inventário ......................... 72

3.2.3 Nível e perfil de buffers ........................................... 75

3.2.4 Análise com exemplos do posicionamento, dimensionamento e

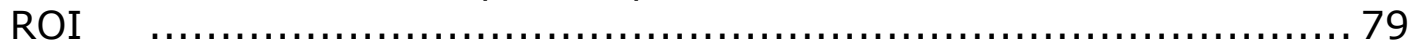

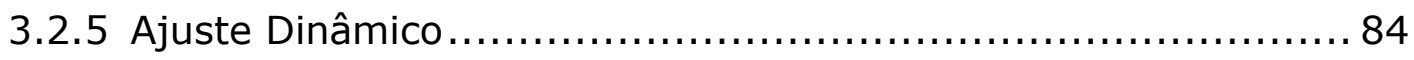

3.2.6 Planejamento Demand Driven .................................... 84

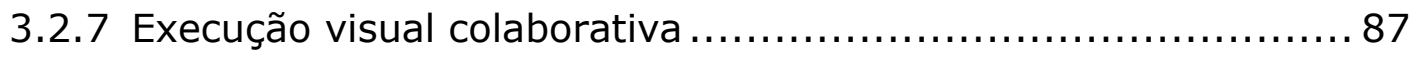

3.3 REVISÃO DA LITERATURA SOBRE DDMRP ............................ 89

3.4 CONCLUSÃO DO CAPÍTULO ............................................. 102

CAPÍTULO 4 - APLICAÇÃO DA SURVEY FUZZY DELPHI............... 107 
4.1 ELEMENTOS DE IMPLEMENTAÇÃO PARA O QUESTIONÁRIO ............ 107

4.2 METODOLOGIA FUZZY DELPHI ................................. 110

4.2.1 Justificativa pela escolha do método ....................... 110

4.2.2 O método Fuzzy Delphi ................................... 111

4.2.3 Processo de aplicação do questionário e caracterização do painel

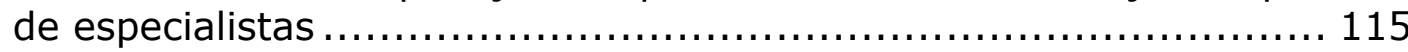

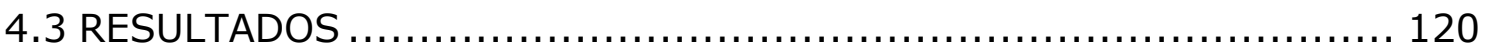

4.3.1 Resultados obtidos pelo Fuzzy Delphi........................ 120

4.3.2 Resultados das questões abertas ............................ 125

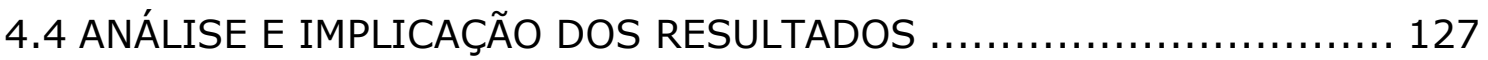

4.4.1 Análise das motivações ..................................... 127

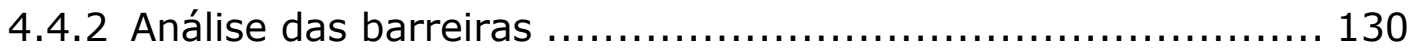

4.4.3 Análise dos fatores críticos de sucesso ..................... 132

CAPÍTULO 5 - CONCLUSÃO ............................................ 136

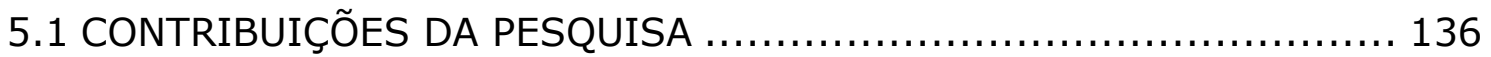

5.2 PESQUISAS FUTURAS E LIMITAÇÕES DA PESQUISA $\ldots \ldots \ldots \ldots \ldots \ldots \ldots . \ldots \ldots$

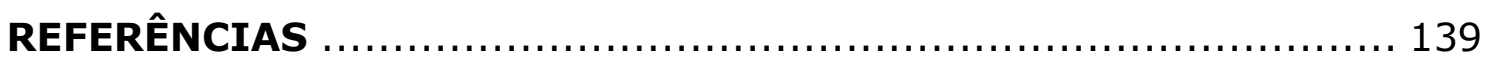

APÊNDICE A - QUESTIONÁRIO PARA OS ESPECIALISTAS .......... 153

APÊNDICE B - CÁLCULOS DO MÉTODO FUZZY DELPHI ............. 160 



\section{CAPÍTULO 1 - INTRODUÇÃO}

\subsection{CONTEXTUALIZAÇÃO E LACUNA DE PESQUISA}

Desde a primeira revolução industrial no fim do século XVIII quando as máquinas movidas a água e a vapor se popularizaram a produção industrial vem evoluindo, passando pelo início do século XX com o uso extensivo da eletricidade e a produção em massa. A década de 1970, deu o início à terceira revolução industrial, que se baseia na automação industrial e uso de tecnologias de informação, e enfim a atualidade que tem se chamado de a Quarta Revolução Industrial, com o uso de sistemas cibernéticos, big data e internet das coisas (Internet of Things) (PREUVENEERS; ILIE-ZUDOR, 2017).

Ao final dos anos de 1970 e começo da década de 1980 os sistemas MRP (Material Requirement Planning) passaram a ser conhecidos e usados nas companhias com o advento da terceira revolução industrial que trouxe grandes avanços com o uso de sistemas e tecnologias de informação (KILIC; ZAIM; DELEN, 2014). Esses sistemas ganharam muita importância e popularidade como uma solução tecnológica por causa da complexidade dos processos industriais e da competição global (KARSAK, ÖZOGUL, 2009).

A partir da década de 1980, tornaram-se conhecidas nas empresas novas tecnologias, técnicas e estratégias de produção que thes permitiam reduzir custos e competir com mais eficiência nos diferentes mercados de atuação. Soluções como o just-in-time, kanban, produção enxuta, gestão da qualidade total, entre outras passaram a ser adotadas em larga escala pelas empresas em busca de melhores resultados, dividindo a atenção com o MRP. Contudo, no início dos anos 2000 as empresas perceberam que já haviam reduzido seus custos aos menores patamares até então e que para melhores resultados precisariam de uma gestão eficiente da cadeia de suprimentos (SIMCHI-LEVI; KAMINSKY; SIMCHI-LEVI, 2003).

Dessa forma, houve nos últimos cinquenta anos uma grande evolução no planejamento e controle da produção das empresas, que passaram a focar também na cadeia de suprimentos como um todo, e não apenas nas 
operações internas (OLHAGER, 2013). Com isso, no final dos anos 90 e inícios dos anos 2000 diversos autores passaram a se dedicar e pesquisar sobre 0 tema e propor segmentações para entendimento e abordagens de gestão para as cadeias de suprimentos.

Autores como Treacy e Wiersema (1993), Fisher (1997) e Lamming et al. (2000) estabeleceram segmentações para as cadeias de suprimentos baseado nos produtos fornecidos e clientes atendidos, adaptando estratégias à demanda e ao tipo de produto. Mason-Jones, Naylor e Towill (2000) classificaram as cadeias de suprimento em Lean, Agile e Leagile.

Gattorna (2009), autor com destacado trabalho empírico no ambiente corporativo, expandiu essas classificações para quatro tipos de cadeias de suprimentos: reabastecimento contínuo, enxutas, ágeis e totalmente flexíveis, e complementou que as empresas podem ter mais de um desses tipos de cadeia para atender produtos e clientes diferentes.

Ainda segundo Gattorna (2009), as empresas estão submetidas à pressão cada vez maior para responder às exigências de todas as categorias de clientes, consumidores e usuários finais. Em alguns setores como o mercado da moda e de produtos tecnológicos de consumo o excesso de produtos e opções crescem exponencialmente, enquanto os ciclos de vida estão diminuindo drasticamente, cenário que favorece as cadeias de suprimentos ágeis.

A respeito da agilidade em cadeias de suprimentos, Christopher (2000), afirma que ela é requerida quando a demanda é volátil, menos previsível e a necessidade por variedade é alta. Ayers e Malmberg (2002) argumentam que a agilidade é necessária quando uma companhia busca ser dirigida pela demanda (Demand Driven), isto é, quando ela troca a lógica de produzir pela previsão para se produzir para atender a pedidos (reagir à demanda). Baseando-se nessas colocações, pode-se entender as cadeias Demand Driven como uma habilidade de responder rapidamente a mudanças na demanda tanto para volumes quanto para variedades de produtos.

Inseridos nesse contexto estão os sistemas de planejamento e controle da produção, e dentre eles o MRP foi o mais implantando nas indústrias durante o fim do século XX, segundo Corrêa e Gianesi (1996). Diversos autores como Duchessi et al. (1989), Yusuf e Little (1998), Tinham (1999) e 
Koh et al. (2000) e Koh, Saad e Jones (2002) relataram em seus estudos dificuldades dos sistemas MRP operarem em ambientes de incerteza.

Com esse cenário de mudanças nas dinâmicas de mercado e grande pressão sobre as empresas foi desenvolvido uma evolução do método MRP, o Demand Driven Material Requirements Planning (DDMRP). Ptak e Smith (2011) apresentam esse novo método na terceira edição da obra Orlicky's Material Requirements Planning, cuja edição original de 1974 é um importante marco para a difusão do MRP. O novo método busca atender a demanda de maneira mais próxima, reduzindo a necessidade de produzir-se por previsão.

O DDMRP é apresentando, pelos autores, como uma solução de vários níveis para planejamento e execução de materiais e inventários. O objetivo é proteger e promover o fluxo de informações e materiais relevantes através do estabelecimento e gerenciamento de buffers de pontos de desacoplamento estrategicamente posicionados (PTAK; SMITH, 2016).

O DDMRP combina elementos de metodologias como, MRP, DRP (Distribution Requirements Planning), Lean, Teoria das Restrições e Six Sigma. Para solucionar pontos conflitantes delas, inovações foram realizadas para a integração harmônica das mesmas (PTAK; SMITH, 2016). O método segue o direcionamento de "posicionar, proteger e puxar" através de uma sequência de cinco componentes: posicionamento estratégico do inventário; perfis e níveis de buffer; ajuste dinâmico; planejamento demand driven e execução visível e colaborativa (PTAK; SMITH, 2016).

Com a maior divulgação do DDMRP aumenta o número de empresas interessadas em implementar o método. Estudos anteriores a respeito da implementação de sistemas de gestão da produção como MRP e ERP destacam a importância do entendimento de fatores relativos à implementação para o sucesso das mesmas. Petroni (2002) destaca que diversas companhias apressaram a introdução do MRP como uma solução mágica e simplista e acabaram não obtendo os resultados esperados pois negligenciaram um aspecto muito importante, a implementação.

Umble, Haft e Umble (2003) com entendimento similar, destacam então que vale a pena examinar os fatores que levam a implementação a ser bem sucedida. Koh, Gunasekaran e Goodman (2011) afirmam que o estudo de fatores de implementação como motivações, barreiras e fatores críticos 
de sucesso ajuda novas empresas no processo de decisão e implementação de novas soluções de gestão, como no caso do ERP II ${ }^{1}$ para o estudo deles.

Desta forma, pode-se considerar similarmente a implementação do DDMRP um processo muito importante para o sucesso deste sistema de planejamento e controle de produção nas empresas. Logo, essa pesquisa se deparou com uma lacuna de pesquisa. Inicialmente, uma pesquisa exploratória inicial nas bases de dados Scopus, Web of Science e Science Direct por palavras-chaves pertinentes ao tema do DDMRP resultou em poucos trabalhos relevantes sobre o tema, e apenas dois trabalhos (um de revista científica e um de congresso) explorando questões da implementação, como, motivações, barreiras e fatores críticos de sucesso e nenhum deles com um método de pesquisa como o proposto neste trabalho, com o uso de uma survey pelo método Fuzzy Delphi.

Além disso, entende-se que por ter sido desenvolvido empiricamente na indústria, o método DDMRP carece de pesquisas acadêmico-científicas que explorem mais profundamente o tema, com métodos científicos já testados. Grande parte das referências encontradas sobre ao tema estão vinculadas ao instituto criado pelos autores do método (Demand Driven Institute), não apresentando trabalhos acadêmicos e científicos sobre o tema.

Considerando-se o contexto apresentado e a lacuna de pesquisa apresentada, desperta-se a seguinte questão de pesquisa que esse trabalho pretende responder: Quais são as motivações, barreiras e fatores críticos de sucesso para a implementação do DDMRP?

Assim, os objetivos da pesquisa serão detalhados no tópico 1.2 a seguir.

\subsection{OBJETIVOS}

O objetivo central desta pesquisa é identificar motivos, barreiras e fatores críticos de sucesso para a implementação do DDMRP em cadeias de suprimentos.

\footnotetext{
${ }^{1}$ Os autores Koh, Gunasekaran e Goodman (2011) referem-se ao ERP II como uma evolução do ERP com objetivo de buscar a colaboração interorganizacional, estendendo o ERP tradicional que oferece eficiência de processos intraorganizacionais. Essencialmente, o ERP II oferece um sistema ERP modularizado, que é baseado na web e fornece colaboração total na cadeia de suprimentos.
} 
Este objetivo central pode ser desdobrado nos seguintes objetivos específicos para melhor organização:

a) evidenciar os elementos e características das cadeias ágeis/ demand driven (ambiente do desenvolvimento do DDMRP);

b) identificar na literatura motivações, barreiras e fatores críticos de sucesso para implementação de métodos de planejamento e controle de produção que são base para o DDMRP (MRP e Lean);

c) apresentar e revisar a literatura acadêmico-cientifica do método DDMRP;

d) aplicar e analisar os resultados da survey pelo método Fuzzy Delphi e por análise crítica baseada na revisão da literatura do tema.

\subsection{JUSTIFICATIVA DO TRABALHO}

Nenhuma referência foi encontrada na literatura pesquisada que utilizasse métodos de tomada de decisão em grupo por especialistas para abordar a implementação do DDMRP. Também, não foram encontrados trabalhos que abordassem o tema de motivações, barreiras e fatores críticos de sucesso para a implementação do DDMRP; apenas foram localizados dois artigos que comtemplavam as motivações, porém eram estudos empíricos, não utilizavam uma metodologia como a proposta para esse trabalho, para buscar a opinião de especialistas por meio do Fuzzy Delphi.

O entendimento da necessidade de trabalhos acadêmicos-científicos sobre o DDMRP é compartilhado pelos poucos autores que trabalharam com o método, como por exemplo Kortabarria et al. (2018), Bahu, Bironneau e Hovelaque (2019) e Miclo et al. (2019). Além disso, Bahu, Bironneau e Hovelaque (2019) complementam que o DDMRP tem despertado a atenção de profissionais da área recentemente, inclusive com alguns países como a França colocando muita atenção sobre esse novo método.

Resumindo esse interesse, Miclo et al. (2019) afirmam que, recentemente, emergiu do mundo prático um repensar fundamental da lógica MRP para melhorar o desempenho geral e a eficácia do método. Além disso, este repensar desafiou algumas das premissas fundamentais do MRP, 
resultando na substituição do estoque de segurança estático por buffers dinâmicos. Assim, criou-se uma nova abordagem - o DDMRP. Os autores completam citando casos de empresas que implementaram essa abordagem, como Allergan, British Telecom, Figeac Aero e Michelin, que relataram melhorias significativas em entrega no prazo, reduzindo a ruptura de estoques e reduzindo os níveis de inventário.

Dessa forma, esse trabalho oferece uma oportunidade para estudar os aspectos das motivações, barreiras e fatores críticos de sucesso para a implementação do DDMRP, ainda não explorados na literatura científica do tema.

\subsection{CARACTERIZAÇÃO DA PESQUISA E MÉTODO CIENTÍFICO PARA O TRABALHO}

Nesta seção são feitas considerações adotadas nesse trabalho quanto a abordagem de pesquisa, método de pesquisa, coleta e análise dos dados. Dentre as várias opções que o pesquisador dispõe para tal aqui são feitas as justificativas dessas escolhas, análises e definições pertinentes.

\subsubsection{Abordagem da Pesquisa}

Quanto à forma de abordagem, segundo Robson (2002), uma pesquisa pode ser qualitativa ou quantitativa. A pesquisa quantitativa é caracterizada por análises de dados numéricos, já a pesquisa qualitativa é caracterizada por uma abordagem investigativa, em que se faz o uso de dados qualitativos, como por exemplo, palavras, observações e opiniões.

A pesquisa aqui proposta, como anteriormente declarado no tópico objetivos, tem o propósito de identificar motivos, barreiras e fatores críticos de sucesso para a implementação do DDMRP em cadeias de suprimentos. Para isso foi utilizada uma survey, com o método Fuzzy Delphi, que está detalhado na seção 4.2 e questões discursivas, mas desde já identifica-se que a pesquisa é caracterizada como uma abordagem mista, qualitativa e quantitativa (BRYMAN, 1989; JUPP, 2006). 
O método Fuzzy Delphi se utiliza de uma metodologia quantitativa aplicada a um questionário apreciado por especialistas para analisar as respostas. Também é realizada uma análise crítica qualitativa, baseada na literatura, para as respostas dissertativas e uma revisão bibliográfica. Logo, atendendo aos dois espectros de abordagem e de acordo com Bryman (2006), que afirma que o uso das duas abordagens em conjunto aumenta as contribuições para novos conhecimentos.

\subsubsection{Propósito da Pesquisa}

Os propósitos de pesquisas são classificados em três tipos por Gil (2009): exploratória, descritiva e explicativa. Dessa forma, entende-se que esta pesquisa de mestrado é caracterizada pelos propósitos descritivo e exploratório.

O propósito descritivo é pelo qual essa pesquisa buscou evidenciar e apresentar as cadeias de suprimentos ágeis e demand driven, a importância das características dessas cadeias no contexto atual e descrever o DDMRP e pesquisas prévias sobre método, embasando e estruturando um modelo conceitual para o trabalho. Além disso buscou-se descrever questões relativas à implementação dos métodos de gestão da produção que são as bases do DDMRP.

Já o propósito exploratório ocorre no âmbito do estudo de campo em que se investiga as questões de implementação, motivações, barreiras e fatores críticos de sucesso, explorando a ocorrência e quais são os principais. O propósito exploratório é adequado quando se tem pouco ou nenhum estudo anterior do tema (COLLINS; HUSSEY, 2005), dessa forma como o tema DDMRP possui poucos estudos e nenhum estudo com foco nessas questões de implementação, a exceção de dois estudo empírico sobre motivações para implementação (BAHU; BIRONNEAU; HOVELAQUE, 2019) e (MCCULLEN; EAGLE, 2015), é adequado uma abordagem com propósito exploratório.

Ainda, quanto ao propósito, Cervo e Bervian (1996) diferenciam a pesquisa em três tipos: bibliográfica, descritiva e experimental.

a) pesquisa bibliográfica: busca explicara um problema ou fenômeno a partir de referências teóricas publicadas em documentos. Procura conhecer e analisar as contribuições 
culturais ou científicas existentes sobre um assunto, tema ou problema. Pode ser parte de uma pesquisa descritiva ou experimental;

b) pesquisa descritiva: observa, registra, analisa e correlaciona fatos ou fenômenos (variáveis) sem manipulá-los. Pode assumir as formas de estudos exploratórios, que buscam familiarizar-se com o tema e obter novas ideias; estudos descritivos, que descreve as características, propriedades e relações do tema da pesquisa; e pesquisa de opinião, que explora pontos de vista e preferências de sujeitos a respeito do tema para tomada de decisão;

c) pesquisa experimental: manipula as variáveis para estudar a relação de causa e efeito de um fenômeno ou tema.

Analisando a classificação de Cervo e Bervian (1996) reforça-se o entendimento que esta pesquisa é do tipo descritiva, com forma exploratória, em acordo com a classificação de Gil (2009).

\subsubsection{Método de Procedimento}

$\mathrm{Na}$ literatura existem vários métodos de procedimentos utilizados como métodos de pesquisa, cada um com suas peculiaridades e enfoques, sendo mais adequados para cada caso em particular.

Miguel (2007) apresenta como principais abordagens de pesquisa no campo da engenharia de produção os seguintes métodos:

a) desenvolvimento teórico conceitual;

b) estudo de caso;

c) modelagem e simulação;

d) pesquisa-ação;

e) pesquisa bibliográfica ou revisão de literatura;

f) pesquisa experimental;

g) survey.

O método de pesquisa bibliográfica, segundo Cervo e Bervian (1996) e Miguel (2007), permite identificar, conhecer, acompanhar e explicar um problema ou tema através de referências publicadas. Além disso, esse método possibilita identificar perspectivas futuras e contribuir com sugestões 
para futuros projetos de pesquisa. Permite, também, uma cobertura maior de fenômenos estudados do que uma pesquisa direta.

Já as investigações por meio de survey têm sido usadas para pesquisas em diferentes campos da engenharia de produção e gestão de operações. A survey tem o objetivo de contribuir para o conhecimento de uma área particular de interesse, por meio de coleta de dados/informações sobre indivíduos ou sobre os ambientes dos quais esses indivíduos fazem parte (MIGUEL; HO, 2012).

Esta pesquisa utilizou dois métodos de procedimento: pesquisa bibliográfica para a construção da revisão de literatura sobre os temas centrais da pesquisa e survey para o estudo aplicado. A revisão de literatura foi importante para a identificação da lacuna de pesquisa, estabelecimento do objetivo de pesquisa, construção do modelo conceitual que embasou a fundamentação para o estudo aplicado e construção de coletânea de trabalhos anteriores sobre o tema. Além disso, permitiu consolidar uma coleção extensa de trabalhos na forma do referencial teórico exploratório, do capítulo 2, que expressa o contexto atual no planejamento de muitas cadeias de suprimentos em âmbito estratégico e operacional.

A survey foi aplicada à trinta e três especialistas que responderam ao questionário desenvolvido para esta pesquisa. Para realizar a análise dos dados foi então utilizada a metodologia Fuzzy Delphi, que está detalhada na seção 4.2 do Capítulo 4 deste trabalho.

O instrumento de coleta de dados escolhido é o questionário distribuído pela internet. Para isso foi utilizado o site SurveyMonkey, ferramenta especializada para elaboração, distribuição e análise de pesquisas survey. Os detalhes da calibragem e construção do questionário estão na seção 1.4.4.

O Quadro 1.1 resume as escolhas do autor sobre a caracterização da pesquisa e método científico para o trabalho dentre as opções consideradas. 
Quadro 1.1 - Caracterização da pesquisa.

\begin{tabular}{|c|c|}
\hline Abordagens de Pesquisa & Abordagem do Trabalho \\
\hline Pesquisa Quantitativa & Pesquisa Quantitativa \\
\hline Pesquisa Qualitativa & Pesquisa Qualitativa \\
\hline Propósitos de Pesquisa & Propósitos do Trabalho \\
\hline Exploratório & Exploratório \\
\hline Descritivo & Descritivo \\
\hline \multicolumn{2}{|l|}{ Preditivo } \\
\hline \multicolumn{2}{|l|}{ Explicativo } \\
\hline \multicolumn{2}{|l|}{ Ação } \\
\hline \multicolumn{2}{|l|}{ Avaliação } \\
\hline Métodos de procedimento de & Métodos de procedimento do \\
\hline Pesquisa & Trabalho \\
\hline \multicolumn{2}{|l|}{ Desenvolvimento teórico conceitual } \\
\hline \multicolumn{2}{|l|}{ Estudo de caso } \\
\hline \multicolumn{2}{|l|}{ Modelagem e simulação } \\
\hline \multicolumn{2}{|l|}{ Pesquisa-ação } \\
\hline Pesquisa bibliográfica & Pesquisa bibliográfica \\
\hline \multicolumn{2}{|l|}{ Pesquisa experimental } \\
\hline Survey & Survey \\
\hline Técnica de Coleta de Dados em & Técnica de Coleta de Dados do \\
\hline Pesquisa & Trabalho \\
\hline Questionário & Questionário \\
\hline \multicolumn{2}{|l|}{ Entrevista Estruturada } \\
\hline \multicolumn{2}{|l|}{ Entrevista Semiestruturada } \\
\hline \multicolumn{2}{|l|}{ Entrevista Desestruturada } \\
\hline \multicolumn{2}{|l|}{ Observação Direta } \\
\hline Informações de arquivos e & \\
\hline documentos & \\
\hline
\end{tabular}

Fonte: Proposto pelo autor.

\subsubsection{Etapas e Estruturação da Survey}

O planejamento da pesquisa survey é fundamental para se alcançar bons resultados. Miguel e Ho (2012) classificam as pesquisas em observacionais e experimentais. Nas pesquisas observacionais não há interação entre o pesquisador e o respondente, apenas a observação. Já as 
pesquisas experimentais os resultados são influenciados pelo pesquisador com intervenções.

Segundo essa classificação dos autores essa pesquisa foi planejada como observacional com um levantamento amostral do tipo amostragem não probabilística, que tem sido muito utilizada para pesquisas de mercado (MIGUEL; HO, 2012). As pesquisas por amostragem não probabilística são menos custosas e mais ágeis, apesar da limitação de inferência dos resultados obtidos (MIGUEL; HO, 2012).

Outro passo importante, segundo os autores, é definir a populaçãoalvo e a população amostrada. Essa pesquisa considerou como potenciais respondentes apenas profissionais com atuação profissional na área de gestão de operações de cadeias de suprimentos, com conhecimento prévio do tema DDMRP e experiência no processo de implementação. Apenas foram considerados profissionais com conhecimento de implantação ou que estavam participando dele durante o momento da pesquisa. Foram selecionadas pessoas da indústria, consultorias e treinamento, fornecedores de soluções tecnológicas e acadêmicos.

Para alcançar o público-alvo foi utilizada a estratégia bola de neve, prevista por Forza (2002). Essa estratégia consiste no redirecionamento da pesquisa a uma rede de contatos por acessibilidade, porém sempre garantindo as premissas da população-alvo.

Após esse passo, segundo Miguel e Ho (2012), é necessário definir os constructos, que são os elementos conceituais dos quais são desdobradas as variáveis a serem testadas. Segundo esses autores, um exemplo seria o constructo "apoio da liderança" para testar se essa variável seria importante para a seguinte proposição: "o apoio da liderança é importante para a implementação do TQM - Gestão da qualidade total?".

Para definir os constructos que foram usados no questionário foi utilizada a revisão bibliográfica dos capítulos 2 e 3, com a lista de constructos selecionados na conclusão dos capítulos.

Após a definição dos constructos é feito a construção do questionário. A estrutura do questionário é do tipo estruturado não disfarçado (BOYD; WETFALL, 1964; MATTAR, 1996; MIGUEL; HO, 2012), que se caracteriza por possuir mais questões fechadas do que abertas e pelo respondente saber 0 
objetivo da pesquisa. Também, se optou por incluir algumas questões abertas.

Dessa forma, pode-se ter o benefício dos dois tipos de questões, abertas e fechadas. As questões abertas são de fácil interpretação, coletam maior quantidade de dados e com maior riqueza e não sofrem influência de respostas pré-determinadas. Já as questões fechadas tem o benefício de serem de fácil preenchimento, relativa facilidade de tabulação e análise de dados e ainda podem ser combinadas com questões abertas (BOYD; WETFALL, 1964; MATTAR, 1996).

Para as questões fechadas optou-se por utilizar a escala de Likert, com cinco pontos de intensidade. Esse tipo de escala é classificado como dados qualitativos ordinais que, segundo Miguel e Ho (2012), se caracterizam por serem ordenáveis, como por exemplo, o grau de satisfação de um atendimento (muito insatisfeito, insatisfeito, nem satisfeito nem insatisfeito, satisfeito, muito satisfeito). O questionário pode ser consultado no Apêndice A do trabalho.

A coleta de dados foi feita por meio do SurveyMonkey e os dados transferidos para o Excel para análise posteriormente. Por fim, o processo de análise de dados seguiu a metodologia Fuzzy Delphi que está detalhada com seu passo a passo na seção 4.2 do Capítulo 4 desse trabalho. A Figura 1.1 a seguir resume as etapas de estruturação da Survey com base no modelo proposto por Forza (2002). 
Figura 1.1 - Etapas de estruturação da Survey.

\begin{tabular}{l} 
1. Ligação com o Nível Teórico \\
Proposições dos constructos com base na revisão bibliográfica \\
Definir alvo e método de coleta de dados e desenvolver questionário \\
2. Projeto da Survey \\
3. Teste Piloto \\
Testar e validar o questinário com especialistas \\
4. Coletar Dados para Teste da Teoria \\
Aplicar a Survey, cadastrar e verificar qualidade das respostas \\
5. Análise dos Dados \\
Análise dos dados pelo método escolhido (Fuzzy Delphi) \\
6. Geração de Relatório \\
\hline Descrever e analisar resultados e fornecer infomações para replicação
\end{tabular}

Fonte: Elaborado pelo autor com base em Forza (2002).

\subsection{PROCESSO DE PESQUISA E ESTRUTURA DO TRABALHO}

Após a caracterização da pesquisa e definição dos métodos de trabalho pode-se apresentar o processo de pesquisa seguido. Segundo Gil (2009), uma pesquisa é um processo sistemático e racional cujo objetivo é desenvolver respostas aos problemas identificados pelo pesquisador. 0 processo desta pesquisa seguiu o modelo proposto na Figura 1.2.

Segundo Fleury (2012), é fundamental construir um modelo antes de realizar a pesquisa, esse modelo é a construção da teoria para responder à pergunta de pesquisa. O modelo aqui proposto inter-relaciona os conceitos de gestão da cadeia de suprimentos com a implantação de métodos de planejamento e controle da produção e o DDMRP, evidenciando questões de implementação desses métodos.

Fleury (2012) recomenda escolher um autor como referência para o modelo e então entender o modelo, criticá-lo, elaborar uma variante para responder a sua pergunta de pesquisa e testar suas hipóteses. Dessa forma, é proposto uma adaptação do método teórico desenvolvido por Bouzon et al. 
(2016), que é um framework dividido em três seções de pesquisa: literatura, análise exploratória e pesquisa empírica.

Para isso, foram alterados alguns aspectos de acordo com a questão de pesquisa proposta nesse trabalho e a teoria do DDMRP. Originalmente, o modelo desses autores foi usado para identificar barreiras para logística reversa. Para isso foram utilizados os métodos Fuzzy Delphi e AHP para realizar uma análise sobre quais barreiras seriam as mais relevantes.

Dessa forma, foi desenvolvido o seguinte modelo para o processo de pesquisa ilustrado pela Figura 1.2.

Figura 1.2 - Modelo do Processo de Pesquisa.

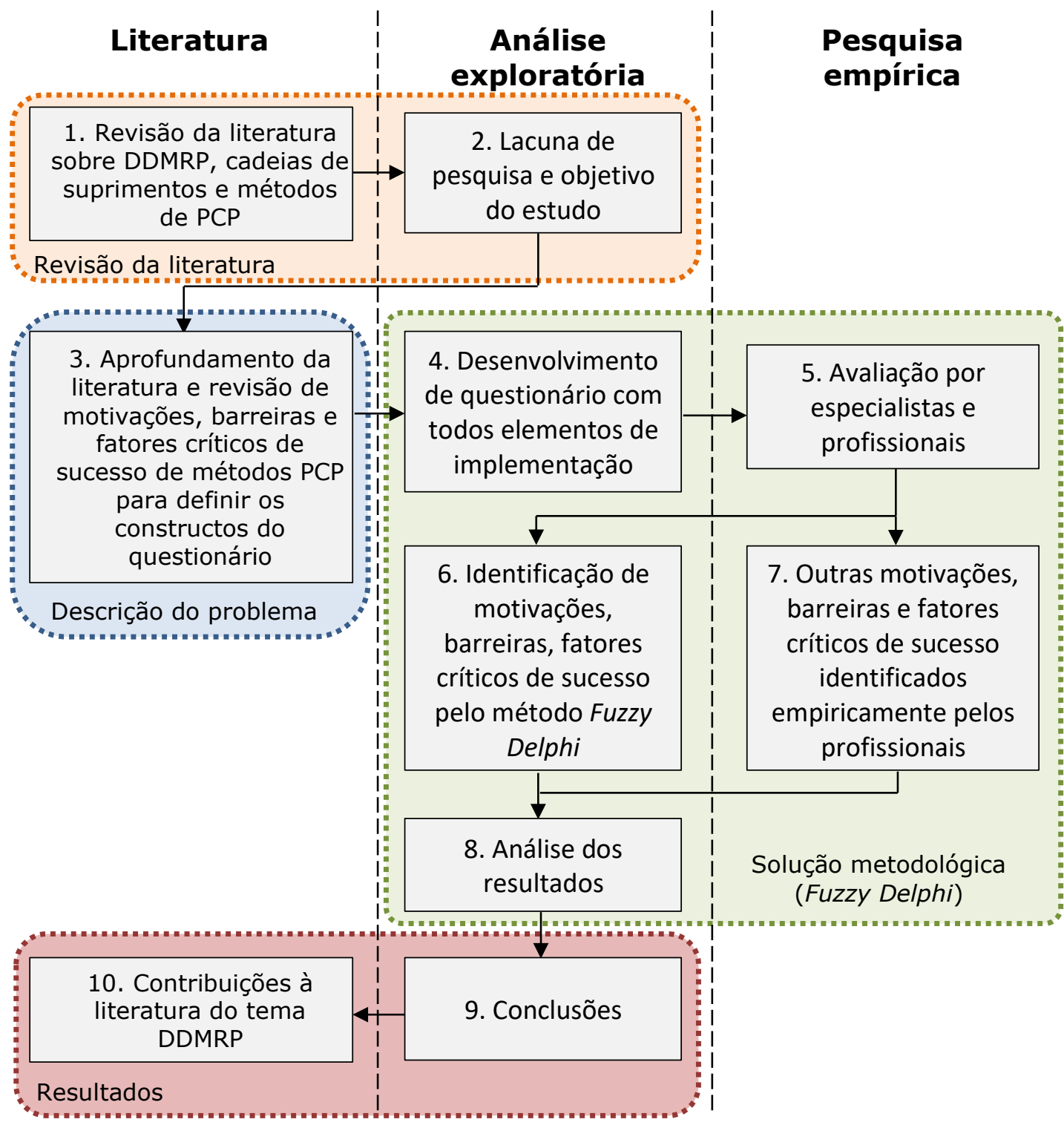

Fonte: Elaborado pelo autor com base em Bouzon et al. (2016). 
A estrutura de organização do texto dessa dissertação de mestrado é a seguinte:

Capítulo 1 - Introdução: no primeiro capítulo são abordados uma contextualização do tema com identificação de uma lacuna de pesquisa, os objetivos definidos para essa pesquisa, a justificativa para o trabalho e finalmente a caracterização da pesquisa e método científico para o trabalho.

Capítulo 2 - Referencial teórico exploratório: nesse capítulo são abordados os temas de gestão da cadeia de suprimentos com foco nas estratégias ágeis e o porquê elas estão sendo buscadas em alguns contextos, destacando suas características e atributos. Passando assim para o entendimento da cadeia de suprimentos demand driven, um conceito ainda pouco explorado que com o tempo vem ganhando atenção. Em um segundo momento é explorado nesse capítulo as questões de implementação, motivações, barreiras e fatores críticos de sucesso de métodos clássicos de gestão da produção, como Lean, MRP e ERP, que foram base para o desenvolvimento do DDMRP. O capítulo é finalizado com os elementos selecionados a partir da literatura para serem constructos do questionário.

Capítulo 3 - Introdução do DDMRP e Revisão Bibliográfica do Tema: nesse capítulo é apresentado o DDMRP, descrevendo suas características, particularidades. Além disso é realizada uma revisão da literatura sobre o tema a fim de resumir e consolidar trabalhos anteriores sobre o método DDMRP. O capítulo é também finalizado com elementos selecionados a partir da literatura para serem constructos do questionário.

Capítulo 4 -Aplicação da Survey Fuzzy Delphi: após o embasamento teórico conceitual feito nos capítulos anteriores nesse capítulo é apresentado o método Fuzzy Delphi, a caracterização dos respondentes selecionados, os resultados da pesquisa e uma análise desses resultados.

Capítulo 5 - Conclusão: nesse capítulo são feitas as conclusões finais do trabalho assim como as considerações finais para o total entendimento da pesquisa, com suas contribuições teóricas e práticas, limitações e proposições para o futuro.

Referências: aqui são apresentadas as obras consultadas para o desenvolvimento dessa dissertação de mestrado. 


\section{CAPÍTULO 2 - REFERENCIAL TEÓRICO EXPLORATÓRIO}

O objetivo deste capítulo é fornecer uma contextualização do momento atual das cadeias de suprimentos para introduzir o conceito de tipos de cadeias de suprimentos e assim destacar as cadeias ágeis e demand driven. Posteriormente é realizada uma revisão bibliográfica exploratória sobre motivações, barreiras e fatores críticos de sucesso para implementação de métodos de planejamento e controle de produção bem disseminados no mercado, assim fornecendo elementos iniciais para posterior análise dos fatores de implementação do DDMRP. Com isso, o capítulo fornece inputs iniciais necessários para a compreensão das cadeias ágeis e demand driven e do processo de implementação de métodos de gestão da produção.

Desta forma, a seção 2.1 apresenta o conteúdo exploratório inicial de gestão e tipos de cadeia de suprimentos, destacando o ambiente atual em que foi desenvolvido o método DDMRP. A seção 2.2 trata do assunto de implantação de métodos de PCP, fornecendo conteúdo para o entendimento dos motivos, barreiras e fatores críticos de sucesso do processo de implantação dessas ferramentas de gestão e a seção 2.3 conclui o capítulo com as motivações, barreiras e fatores críticos de sucesso selecionados para serem aplicados ao questionário do trabalho, com os elementos gerais, comuns a outros métodos de PCP e relativos aos tipos de cadeias.

\subsection{CONTEXTUALIZAÇÃO DO CENÁRIO ATUAL DE GESTÃO DA CADEIA DE SUPRIMENTOS}

\subsubsection{Definição geral do conceito de gestão da cadeia de suprimentos}

O termo gestão da cadeia de suprimentos foi originalmente introduzido por consultores que trabalhavam na área no começo dos anos de 1980, ganhando posterirormente muita atenção de toda comunidade envolvida nesse campo. No começo dos anos 1990, a comunidade acadêmica iniciou estudo para estruturar o conhecimento sobre gestão da cadeia de suprimentos (LAMBERT; COOPER; PAGH, 1998). 
Lambert, Cooper e Pagh (1998) recomendam a definição de gestão da cadeia de suprimentos desenvolvida pelo The Global Supply Chain Forum, que a define da seguinte forma: integração dos principais processos de negócios partindo dos usuários finais até os fornecedores primários que provém produtos, serviços e informações que agregam valor para os consumidores e outros stakeholders.

Os autores Simchi-Levi, Kaminsky e Simchi-Levi (2010, p. 33) adotam a seguinte definição para a gestão da cadeia de suprimentos:

A gestão da cadeia de suprimentos é um conjunto de abordagens que integra, com eficiência, fornecedores, fabricantes, depósitos e pontos comerciais, de forma que a mercadoria é produzida e distribuída nas quantidades corretas, aos pontos de entrega e nos prazos corretos, com o objetivo de minimizar os custos totais do sistema sem deixar de atender às exigências em termos de nível de serviço.

Bowersox, Closs e Cooper (2012) descrevem a gestão da cadeia de suprimentos como a colaboração entre empresas para conectar fornecedores, consumidores e outros parceiros a fim de aumentar a eficiência e gerar valor ao consumidor final. Os autores ainda pontuam a distinção entre logística e gestão da cadeia de suprimentos, sendo a logística o movimento de produtos e informações relativas a eles de um lugar para o outro, incluindo transporte, armazenagem, movimentação de materiais, estoques e informações referentes a isso. A gestão da cadeia de suprimentos é algo estratégico, uma parte maior do negócio.

Recentemente, novos conceitos foram introduzidos à gestão da cadeia de suprimentos como, por exemplo, a preocupação ambiental e tecnologias entre outros com menor ocorrência. A questão da logística reversa e o que os autores chamam de closed-loop supply chain impactaram em novas definições. Govindan, Soleimani e Kannan (2015) tratam a definição de closed-loop supply chain management como o projeto, controle e operação de um sistema para maximizar a criação de valor durante todo o ciclo de vida de um produto, com recuperação dinâmica de valor de diferentes tipos e volumes de retorno ao longo do tempo.

Analisando a literatura sobre cadeia de suprimentos, percebe-se alguns aspectos fundamentais compartilhados por autores (Lambert; Cooper; Pagh, 1998; Simchi-Levi, Kaminsky; Simchi-Levi, 2010; Bowersox, Closs; Cooper, 2012): 
a) o fluxo: de materiais e informações que ocorre entre os elos;

b) a gestão: a organização, sincronização e coordenação desses fluxos e processos ao longo dos elos da cadeia;

c) otimização: busca-se a eficiência a fim de entregar os produtos e serviços requeridos com o menor custo e uso de recursos possíveis;

d) valor ao cliente: foco no cliente, atendendo as expectativas ou superando elas.

Tendo em vista essas referências e definições, observa-se na literatura diversas estratégias para as cadeias de suprimentos atenderem esses requisitos e necessidades de acordo com o mercado em que atuam. Autores propuseram, ou empiricamente relataram, estratégias a fim de orientar as empresas de como alcançar seus objetivos e competir no mercado de maneira mais eficaz.

Na próxima seção, 2.1.2, serão apresentadas brevemente os tipos de cadeias de suprimentos baseadas nessas estratégias e um contexto do atual cenário nesse mercado.

\subsubsection{O ambiente atual e as cadeias de suprimentos ágeis}

Para iniciar essa discussão é importante destacar que existem diferentes tipos de cadeias de suprimentos. Birhanu, Lanka e Rao (2014) por meio de uma survey, identificaram quatro grandes correntes de pensamento que classificam esses tipos de cadeias de acordo com critérios específicos. A seguir são apresentadas essas quatro correntes que classificam as cadeias de suprimentos por tipos.

- Cadeia de suprimento eficiente ou responsiva: essa classificação explora o trade-off entre utilização de estratégias que aumentam a responsividade, como por exemplo o uso de estoques, inventário e redução de lead time e estratégias para redução de custos (POIGER, 2010; DAVIS, 1993; BIRHANU; LANKA E RAO, 2014).

- Cadeia de suprimento enxuta ou ágil: essa classificação explora a habilidade em lidar com a incerteza da demanda para volume e variedade de produtos. Para ambientes com baixa demanda 
por flexibilidade de produção e variedade de produtos uma abordagem enxuta é a mais adequada, já para alta demanda de flexibilidade e variedade de produtos o uso da estratégia ágil é o mais adequado (NAIM; NAYLOR E BARLOW, 1999). Ainda dentro dessa classificação, Mason-Jones, Naylor e Towill (2000) descrevem um terceiro tipo de cadeia híbrida, a Leagile. Esse tipo é adequado em mercados que exigem características tanto enxutas como ágeis, há o posicionamento de um ponto de desacoplamento, um estoque intermediário de produtos semiacabados, assim, utiliza-se processos enxutos em uma ponta da cadeia, aumentando eficiência e reduzindo custos e na outra ponta utiliza-se processos ágeis e responsivos para atender demandas flutuantes e instáveis, possibilitando variabilidade de produtos e respostas rápidas.

- Cadeia de suprimento eficiente, responsiva, risco compartilhado ou ágil: essa classificação foi proposta por Lee (2002) com base na incerteza da demanda e do suprimento. A Figura 2.1 representa a ideia dessa classificação.

- Cadeia de suprimentos puxada ou empurrada: essa classificação propõe a identificação das cadeias pelo cumprimento de ordens de produção. No sistema empurrado as ordens de produção são decididas com base em previsões de longo prazo, já nos sistemas puxados as ordens são geradas com base na demanda atual e real (CHOPRA; MEINDL, 2007; SIMCHI-LEVI; KAMINSKY; SIMCHI-LEVI, 2010). Harrison, Lee e Neale (2003) afirmam que uma cadeia de suprimentos é quase sempre uma combinação das estratégias puxada e empurrada (push-pull system). Olhager (2003) pontua que esse sistema híbrido é composto por um elemento empurrado, aquisição de matéria prima, e um elemento puxado, a produção. 
Figura 2.1 - Matriz de classificação para estratégias de cadeias de suprimentos.

\begin{tabular}{|c|c|c|c|}
\hline \multirow{4}{*}{ 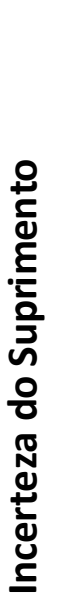 } & \multirow[b]{3}{*}{$\begin{array}{c}\text { Baixo } \\
\text { (Processo Estável) }\end{array}$} & \multicolumn{2}{|c|}{ Incerteza da Demanda } \\
\hline & & Baixo (Produtos Funcionais) & Alto (Produtos Inovadores) \\
\hline & & $\begin{array}{c}\text { Cadeias de Suprimentos } \\
\text { Eficientes }\end{array}$ & $\begin{array}{c}\text { Cadeias de Suprimentos } \\
\text { Responsivas }\end{array}$ \\
\hline & $\begin{array}{c}\text { Alto } \\
\text { (Processo Evolutivo) }\end{array}$ & $\begin{array}{l}\text { Cadeias de Suprimentos } \\
\text { de Risco Compartilhado }\end{array}$ & $\begin{array}{c}\text { Cadeias de Suprimentos } \\
\text { Ágeis }\end{array}$ \\
\hline
\end{tabular}

Fonte: Lee (2002).

Concomitante aos estudo sobre classificação de tipos de cadeias de suprimentos, cresceu a percepção de especialistas e pesquisadores em uma mudança na dinâmica do mercado consumidor. Essa mudança é percebida por uma maior incerteza e volatilidade. Christopher (2000), notando esse movimento, afirmou que os mercados turbulentos e voláteis estavam se tornando uma norma, uma vez que a redução do ciclo de vida dos produtos e as forças econômicas globais criavam novas incertezas.

Com entendimento similar, Gattorna (2009) destacou que as empresas estão submetidas à pressão cada vez maior para responder às exigências de todas as categorias de clientes, consumidores e usuários finais. Blackburn et al. (2015) descrevem esse cenário pelo acrônimo VUCA, que significa, volatilidade, incerteza, complexidade e ambiguidade. Essa expressão foi cunhada primeiramente em um estudo do United States Army War College e posteriormente adotado pelo mundo dos negócios e gestão da cadeia de suprimentos.

Blackburn et al. (2015) afirmam que esse ambiente caracterizado pela volatilidade, incerteza, complexidade e ambiguidade tem um impacto claro na previsibilidade, e consequentemente na previsão da demanda. Os autores propuseram, nesse estudo, um novo método de predição de demanda baseado em um modelo estatístico e concluíram que os métodos tradicionais usados atualmente não são adequados para o cenário VUCA. 
Assim, diversos autores destacam a importância da agilidade e flexibilidade nesse mercado impactado pelo contexto VUCA. Eckstein et al. (2015) afirmam que para operar no ambiente VUCA e nas incertezas resultantes dele nas cadeias de suprimentos, a adaptabilidade e a agilidade são cada vez mais importantes. Com raciocínio similar, Denning (2018) aconselha a adoção de estratégias que proporcionem agilidade e flexibilidade para obter sucesso na era da disrupção.

Ainda sobre flexibilidade, Christopher e Holweg (2011) afirmam que à medida que a incerteza aumenta no futuro, o valor da flexibilidade aumentará, gerando ganhos para as cadeias de suprimentos flexíveis. Os autores citam o caso bem sucedido da empresa WDF, maior rede duty-free do Reino Unido, que diante da incerteza e demanda cada vez mais imprevisível fizeram uma transição de "forecast-driven" (orientado por previsões, em uma tradução direta e livre feita pelo próprio autor) para um modelo "demand-driven" (orientado para a demanda, em uma tradução direta e livre feita pelo próprio autor).

Desta forma, compartilhando entendimento similar a esses pesquisadores, as cadeias de suprimentos que buscam agilidade, flexibilidade e se orientar pela demanda conseguem melhor desempenho no ambiente atual dos mercados. Assim, a próxima seção aprofunda-se nas definições das cadeias ágeis e seus atributos, como forma de gerar insights para os constructos do questionário, principalmente sobre motivações para adoção do DDMRP.

\subsubsection{A agilidade como estratégia em cadeias de suprimentos}

Yusuf et al. (2014) através de uma revisão bibliográfica reportaram algumas das principais definições de agilidade em cadeias de suprimentos na visão de autores destacados no tema, identificando também dimensões da agilidade na visão desses pesquisadores. A seguir o Quadro 2.1 resume as principais definições de agilidade em cadeias de suprimentos. 
Quadro 2.1 - Definições de Agilidade em Cadeias de Suprimentos.

Autores

Burgess (1994)

Vastag et al. (1994)

Goldman et al. (1995)

Yusuf et al. (1999)

Mason-Jones e Towill (1997, 1999)

Christopher (2000, 2005)

Harland (1996),

Tolone (2000),

Gosling et al. (2010)

van Hoek et al. (2001)

\section{Definição de Agilidade em nível de Cadeias}

\section{de Suprimentos}

Síntese de diversas tecnologias e métodos de organização de sistemas de produção.

Agilidade é ser capaz de fornecer produtos e serviços de alta qualidade e altamente personalizados.

Integração intra-empresarial e interempresarial para flexibilidade e velocidade de mercado, possibilitada por tecnologias avançadas de fabricação, comunicação e transporte.

Agilidade significa entregar produtos e serviços com alto conteúdo de informação e agregação de valor aos clientes, estando pronto para mudanças, valorizando o conhecimento e as habilidades humanas e a formação de parcerias virtuais.

Agilidade é a exploração bem-sucedida de bases competitivas através da integração de recursos reconfiguráveis e melhores práticas em um ambiente rico em conhecimento para fornecer produtos e serviços orientados para o cliente em um ambiente de mercado em rápida mudança. Usar o conhecimento de mercado e corporação virtual para explorar oportunidades lucrativas em ambientes de negócios voláteis.

A capacidade de uma organização de responder rapidamente às mudanças na demanda, tanto em termos de volume quanto de variedade. Integração eficaz da cadeia de suprimentos e estabelecimento de relacionamentos próximos e de longo prazo com clientes e fornecedores. Agilidade é tudo sobre a capacidade de ser responsivo ao cliente e as turbulências de mercado através de recursos específicos. 
Quadro 2.1 - Definições de Agilidade em Cadeias de Suprimentos.

\section{Autores}

Aitken et al. (2002),

Michael e

Wempre (2002),

Swafford et al. (2008),

Gosling et al. (2010)

Agarwal et al. (2006),

Prajogo e Sohal (2006),

Romano (2000),

Naim e Gosling (2011),

Kisperska-Moron e de Haan

(2011)

(2009), Mike et al. (2012)

Jain et al. (2008)

Definição de Agilidade em nível de Cadeias de Suprimentos

\begin{tabular}{|c|c|}
\hline (2 & $\begin{array}{l}\text { produto e inovação de processo; tudo voltado para } \\
\text { a flexibilidade e redução do lead time. }\end{array}$ \\
\hline $\begin{array}{l}\text { Braunscheidel e Suresh } \\
\text { (2009), Mike et al. (2012) }\end{array}$ & $\begin{array}{l}\text { A agilidade é uma iniciativa de gerenciamento de } \\
\text { riscos que é necessária para fornecer um valor } \\
\text { superior e para gerenciar os riscos de interrupção } \\
\text { e garantir o fornecimento ininterrupto de serviços. } \\
\text { A agilidade é necessária para mitigação de risco e } \\
\text { resposta rápida. }\end{array}$ \\
\hline Jain et al. (2008) & $\begin{array}{l}\text { A agilidade pode ser avaliada com critérios rígidos } \\
\text { e flexíveis de flexibilidade, rentabilidade, } \\
\text { qualidade, "inovatividade", proatividade, } \\
\text { velocidade de resposta, custo e robustez. }\end{array}$ \\
\hline
\end{tabular}

Fonte: Adaptado de Yusuf et al. (2014, p. 533).

Foram ainda identificadas como principais dimensões da agilidade as seguintes (YUSUF et al., 2014):
a) aumentar o valor ao cliente;
b) aproveitar o impacto de pessoas e informações;
c) cooperar para competir;
d) dominar a mudança e a incerteza.

A partir desses estudos, pode-se definir as cadeias de suprimentos ágeis como um conjunto de empresas que trabalham colaborativamente para 
satisfazer os seus consumidores, maximizando o valor de seus produtos e serviços, aumentando a flexibilidade e a agilidade de resposta a mudanças de demanda, construindo relacionamentos para aproveitar oportunidades de mercado mirando confiabilidade, qualidade e custos competitivos.

Percebe-se pelas definições de agilidade que alguns pontos são comuns, sendo importantes para atingir o objetivo final. Entre esses pontos pode-se destacar o fornecimento de produtos e serviços sem interrupções, compressão do lead time para proporcionar respostas mais ágeis e investimentos em inovações, de produtos e processos, criando diferenciação de produtos e serviços.

Lin, Chiu e Chu (2006) propuseram alguns atributos para medir um índice de agilidade em cadeias de suprimentos. Os autores identificaram como características principais para essas cadeias a responsividade, competência, flexibilidade e rapidez. Os quatro atributos principais que constituem o índice proposto são: o relacionamento colaborativo, integração de processos, integração de informação e sensibilidade do consumidor e do marketing.

Voltolini (2010) sintetizou os principais atributos das cadeias de suprimentos ágeis, através de um levantamento bibliográfico. O Quadro 2.2 apresenta esses atributos com uma breve descrição.

Quadro 2.2 - Atributos das Cadeias de Suprimentos Ágeis.

\begin{tabular}{cl}
\hline $\begin{array}{c}\text { Atributos das Cadeias } \\
\text { de Suprimentos Ágeis }\end{array}$ & \multicolumn{1}{c}{ Descrição } \\
\hline Flexibilidade & Habilidade de adaptar-se a novas situações \\
\hline \multirow{2}{*}{$\begin{array}{c}\text { Trompartilhamento de frequente e estruturada de arquivos e } \\
\text { Informações }\end{array}$} & $\begin{array}{l}\text { disponibilização de acesso a dados das empresas } \\
\text { parceiras, em especial para sinalizar posição de } \\
\text { estoques, vendas realizadas e previsões de vendas. }\end{array}$ \\
Uso intensivo de & $\begin{array}{l}\text { Uso de internet, softwares de integração e outras } \\
\text { ferramentas eletrônicas com objetivo de permitir } \\
\text { comologia da Informação }\end{array}$ \\
& $\begin{array}{l}\text { compartilhar dados sobre ponto de vendas e estoques } \\
\text { na cadeia de suprimentos. }\end{array}$ \\
\hline
\end{tabular}


Quadro 2.2 - Atributos das Cadeias de Suprimentos Ágeis.

Atributos das Cadeias
de Suprimentos Ágeis

\begin{tabular}{cl}
\hline \multirow{2}{*}{ Inovação Colaborativa } & $\begin{array}{l}\text { Permite o envolvimento do consumidor na inovação } \\
\text { de produtos, para lançamentos e pedidos já } \\
\text { colocados que podem ser customizados. }\end{array}$ \\
\hline & Uma cadeia de suprimentos orientada à demanda \\
tem como objetivo atender o consumidor final da \\
Orientação à demanda & melhor forma, para isso, estrutura-se para \\
(Visibilidade) & movimentar bens segundo a necessidade dos \\
& clientes. \\
\hline Customização & Trata-se de desenvolver processos para oferecer \\
& produtos e serviços com diferenciações conforme \\
& requerido pelos clientes. Pressupõe atender de uma \\
forma economicamente competitiva.
\end{tabular}

Compressão do Tempo através da redução do lead time, seja através de estoques ou processos mais rápidos e simplificados.

Capacidade excedente Estratégia de sobra de capacidade de produção e logística para atender pedidos.

Significa dar poder de decisão aos funcionários e aos

Empowerment e times times de profissionais de diversas especialidades, multifuncionais responsáveis por conduzir parte dos processos da cadeia de suprimentos.

Desenvolvimento e compartilhamento de competências e habilidades pessoais Os funcionários, responsáveis por definir o plano de demanda e de produção e materiais, principalmente, precisam de treinamentos e formação adequados para conduzir ações envolvendo várias organizações e setores.

Grupo de empresas que se organiza com o objetivo

Empresas Virtuais de atender uma demanda específica por tempo determinado. Dá ênfase a relações flexíveis com uso de tecnologia da informação. 
Quadro 2.2 - Atributos das Cadeias de Suprimentos Ágeis.

\begin{tabular}{cl}
\hline $\begin{array}{c}\text { Atributos das Cadeias } \\
\text { de Suprimentos Ágeis }\end{array}$ & \multicolumn{1}{c}{ Descrição } \\
\hline \multirow{2}{*}{ Processos simultâneos } & $\begin{array}{l}\text { Realizar de maneira simultânea atividades e } \\
\text { processos que serão reunidos em momento seguinte, } \\
\text { tem como objetivo reduzir tempo de resposta de } \\
\text { lançamentos de novos produtos. }\end{array}$ \\
\hline \multirow{2}{*}{ Postponement } & $\begin{array}{l}\text { Postergar a definição da forma final ou o } \\
\text { deslocamento de um produto dentro da cadeia de } \\
\text { suprimentos até o pedido do cliente. }\end{array}$ \\
\hline Teoria das Restrições & $\begin{array}{l}\text { Teoria que afirma que uma cadeia de suprimentos } \\
\text { não pode ser mais veloz e eficaz que seu elo mais } \\
\text { fraco. As restrições são definidas quanto ao tipo, } \\
\text { físico ou não físico, e localização, interna a cadeia ou } \\
\text { externa. }\end{array}$ \\
\hline mojeto de produto & $\begin{array}{l}\text { Aplicado ao desenvolvimento de produto, busca } \\
\text { utilizar estruturas comuns e complementares nos } \\
\text { produtos, gerando redução de custos e maior rapidez } \\
\text { de entrega. }\end{array}$ \\
\hline
\end{tabular}

Gestão de projetos

Metodologia para estruturar a realização de projetos, com objetivo de otimizar recursos e cumprir prazos.

Fonte: Adaptado de Voltolini (2010).

Dessa forma, com essas definições percebe-se vários pontos que podem ser indutores do interesse de empresas e cadeias de suprimentos a adotar a estratégia ágil para suas operações. A crescente incerteza que afeta os mercados potencializa esse interesse e, de acordo com autores destacados na área de gestão de operações, as cadeias de suprimentos ágeis estão mais preparadas para lidar com esse cenário. O tópico a seguir é dedicado a descrever as cadeias do tipo demand driven que também vem ganhando destaque e possui algumas características similares as ágeis.

\subsubsection{Demand Driven Supply Chain}

A definição da Demand Driven Supply Chain (DDSC) pode ser entendida como uma evolução das ágeis e responsivas, agregando elementos 
dessas e trazendo novos conceitos. Essa seção do trabalho tem como objetivo evidenciar as características e apresentar definições da DDSC na visão de autores que trabalharam com o tema.

As Cadeias de Suprimentos Demand Driven podem ser definidas como uma rede de sistemas, tecnologias e processos de negócios que detectam e respondem a sinais de demanda em tempo real, através de uma rede de clientes, fornecedores e funcionários. Esse tipo de cadeia de suprimentos precisa ser ágil com a habilidade de responder rapidamente a mudanças na demanda, tanto para volume quanto variedade de produtos (CHRISTOPHER, 2000; FRISCIA et al., 2009; BUDD; KNIZEK; TEVELSON, 2012).

Devido a essas características, muitas empresas estão tentando mudar para a estratégia Demand Driven, elas fazem isso mudando de uma estratégia make-to-forecast (fazer por previsão) para uma make-to-order (fazer sob encomenda). As cadeias de suprimento demand driven são as que obtêm informações para decisões de produção e estoque a partir da demanda em tempo real, não da demanda prevista (AYERS; MALMBERG, 2002).

Gollamudi (2013) cita que as empresas devem buscar serem demand driven por seis motivos principais: os mercados são voláteis, a demanda é flutuante, os produtos são especializados, produtos possuem alta variedade, necessidades de instalações físicas de baixo custo e foco externo.

Ogawa e Piller (2006) relatam em seu estudo que empresas líderes do setor de produtos de consumo, como Procter \& Gamble e Walmart, implantaram estratégias de DDSC em seus processos de planejamento com o uso de dados de ponto de vendas, compartilhamento de informações e parcerias com seus fornecedores para melhorar seus níveis de serviço, superar desafios de mercado e impulsionar a satisfação dos clientes.

As cadeias demand driven visam uma resposta rápida e personalizada à demanda volátil, em vez do fornecimento antecipado de produtos padrão em grandes volumes (FISHER, 1997; CHRISTOPHER, 2005). Essa variedade de cadeia pode ser definida como uma cadeia de suprimentos na qual todos os atores envolvidos são sensíveis e responsivos a informações de demanda do cliente final e atendem a essas demandas variadas e variáveis de maneira oportuna, no tempo, e economicamente eficiente (VERDOUW et al., 2011).

A cadeia de suprimentos demand driven baseia-se em quatro pilares principais. Primeiro, os níveis de demanda e estoque precisam ser claros e 
transparentes em todos os elos da cadeia. Segundo, uma infraestrutura robusta ajuda as entidades da cadeia a se ajustarem e correspondem a mudanças instantâneas na oferta e na demanda. Terceiro, a coordenação entre as partes interessadas da cadeia permite que operem de maneira mais eficiente e organizada. Quarto, a otimização do desempenho total da cadeia fornece às empresas redução de custos e aprimora o atendimento ao cliente (BUDD et al., 2012; GANJI; SHAH; COUTROUBIS, 2018).

Ayers e Malmberg (2002) propuseram uma sistemática de três elementos a ser seguida para elevar o nível de alinhamento com a lógica Demand Driven. Os elementos são os seguintes:

a) diminuir o lead-time dos processos: diminuir os tempos de ciclo os processos do caminho crítico a fim de diminuir o lead-time do processo de produção;

b) adotar o modelo econômico de fluxo: substituir o modelo de lotes por modelo de fluxo;

c) substituir a previsão pela demanda: compartilhar informações ao longo da cadeia para todos os membros terem acesso aos números de vendas em tempo real.

Esses passos propostos por Ayers e Malmberg (2002) visam proporcionar agilidade de resposta a mudanças na demanda. O conceito do lead time como fator de vantagem competitiva já foi relatado por outros autores. Disney et al. (2016) aponta que o lead time está no centro da teoria da competição baseada no tempo. A redução do lead time tem como objetivo primário atender os pedidos e requisitos dos clientes mais rapidamente. Como consequência outros benefícios são alcançados como redução de inventário e estoques, perdas por problemas de qualidade e obsolescência (STALK, 1988; SURI, 1998).

Stalk (1988) afirma que empresas com sistemas que proporcionam respostas rápidas e flexíveis conseguem absorver melhor a variedade de produtos e a inovação, diferentemente das empresas que buscam economia de escala movendo parte do processo produtivo para países subdesenvolvidos em busca de redução de custos.

Budd et al. (2012) citam como principais benefícios das cadeias demand driven os seguintes:

a) redução de inventário; 
b) redução do uso de capital de giro;

c) melhor precisão da previsão;

d) redução de custo de transporte;

e) otimização da infraestrutura;

f) redução de custos de expedição de pedidos;

g) redução do custo operacional;

h) redução de pessoal;

i) diminuição do tempo de planejamento de vendas e operações;

j) redução de vendas perdidas;

k) melhoria na venda e satisfação do cliente.

Em complemento, Eagle (2017) afirma que mesmo em um cenário VUCA as seguintes melhorias de desempenho são possíveis para as empresas que adotam a abordagem demand driven:

- obtenção de altos níveis de serviço planejado;

- redução do estoque médio em até $50 \%$;

- redução de custos em até $20 \%$ com redução de horas extras não planejadas ou aumento da utilização da capacidade;

- redução do lead time planejado em até $85 \%$.

Um dos principais atributos das cadeias demand driven é a flexibilidade. Hadaya e Cassivi (2007) classificam a flexibilidade no contexto de cadeia de suprimentos em cinco dimensões com base na teoria de Vickery, Calantone, Droge (1999):

a) flexibilidade de volume: dimensão que captura a habilidade de ajustar a capacidade de produção;

b) flexibilidade de lançamento: dimensão que captura a habilidade de lançar e introduzir novos produtos ou variações de maneira ágil e eficaz;

c) flexibilidade de acesso: dimensão que captura a habilidade de cobrir a rede de distribuição, ou seja, habilidade de entregar os produtos nos pontos necessários;

d) flexibilidade de produto: dimensão que captura a habilidade de produzir e customizar diferentes produtos com características diferentes;

e) flexibilidade de resposta ao mercado alvo: dimensão que captura a habilidade de responder as necessidades do mercado alvo. 
Mendes, Leal e Thomé (2016) afirmam que a estratégia demand driven foca em responder rapidamente e de maneira eficiente os pedidos dos clientes, de acordo com as necessidades de tempo, preço, qualidade e quantidade. Assim, percebe-se um alinhamento em colocar o cliente como elemento central, buscando sempre atender suas necessidades.

A estratégia demand driven consegue embarcar mais de uma das bases primárias da competição propostas por Cohen e Roussel (2013). A inovação, experiência do cliente e qualidade são objetivos e requisitos a serem atingidos.

Gattorna (2009) cita como exemplo de sucesso na implantação de uma estratégia ágil a empresa de vestuários Zara. Dentro de um mercado extremamente dinâmico, conhecido como fast fashion, a agilidade em entregar novidades é fundamental. A empresa adquire matérias primas de mercados no extremo oriente, em busca de custos baixos, mas reserva capacidade de produção antecipadamente em locais próximos ao seu mercado consumidor, e utiliza técnicas de postponement e processos ágeis para produzir novidades e entregá-los com rapidez.

O mesmo autor complementa que em situações de demanda incerta é inútil busca precisão na previsão, uma vez que a previsão não é realmente possível em nenhum nível. Segundo o autor, o princípio orientador para esses casos é planejar pela capacidade, mas executar pela demanda.

Em acordo com a teoria de Cohen e Roussel (2013) para gestão estratégica de cadeias de suprimentos, a bibliografia consultada ao longo desse capítulo destaca a importância de a cadeia estar alinhada à estratégia do negócio, nesse caso, ser sensível à demanda para ser bem-sucedida nesse contexto.

Por fim, pode-se destacar as palavras do professor pesquisador Martin Christopher (Cranfield University) a respeito da abordagem demand driven para as cadeias de suprimentos. Segundo ele, essa abordagem é poderosa e prática e espera-se que possa continuar a ganhar força e se desenvolver na indústria (EAGLE, 2017). 


\subsection{MOTIVAÇÕES, BARREIRAS E FATORES CRÍTIVOS DE SUCESSO PARA IMPLEMENTAÇÃO DE SISTEMAS DE PLANEJAMENTO E CONTROLE DA PRODUÇÃO}

O objetivo dessa seção do trabalho é gerar insights para a identificação e levantamento de pontos importantes na implementação de sistemas de PCP. Desta forma, busca-se entender o processo de implementação desse tipo de solução a fim de gerar inputs para o modelo teórico-conceitual para o estudo de campo, identificando motivações, barreiras e adaptações necessárias para o caso específico do DDMRP que é o sistema estudado nesta pesquisa.

A literatura acerca de fatores de sucesso e falha na implementação de sistemas de PCP é vasta, porém para o foco deste trabalho os temas específicos mais relevantes são sobre o processo de implementação de sistemas MRP, ERP e sistemas baseados na mentalidade Lean, dada a proximidade às essências evidenciadas na criação, desenvolvimento e implementação do DDMRP.

Para localizar esses estudos foram feitas buscas nas três principais bases de dados, Web of Science, Scopus e Engineering Village (BUCHINGER; CAVALCANTI; HOUNSELL, 2014), com as seguintes strings de busca: (("MRP" OR "ERP") AND "implementation barriers"), (("MRP" OR "ERP") AND ("implementation motivation" OR "implementation driver")), (("MRP" OR "ERP") AND "implementation critical success factors"), ("Lean" AND "implementation barriers"), ("Lean" AND ("implementation motivation" OR "implementation driver")) e ("Lean" AND "implementation critical success factors").

Wilson, Desmond e Roberts (1994) investigaram as razões para o sucesso ou falha na implementação do MRP II. Segundo ou autores é difícil definir com precisão um critério para avaliar o sucesso na implantação desse tipo de sistema, porém, eles identificaram alguns fatores que podem dificultar a implementação. A seguir são apresentados esses fatores:

a) mudança no mercado do produto: uma dificuldade externa a organização pode ser declínio ou mudança no mercado do segmento de produtos da empresa; 
b) software: opções de software que não se adequam a realidade da empresa ou customizações no software pode levar a dificuldades na implantação;

c) falta de suporte da alta gerência: relacionado a diferentes estilos de gestão, cultura e estrutura organizacional. Não se deve apenas fornecer apoio financeiro, mas também participar ativamente da implementação da solução;

d) mudanças de pessoal: mudanças em funcionários que participam diretamente da implementação podem levar a atrasos e outras complicações;

e) falta de disciplina: relatos de falta de disciplina no chão de fábrica, engenharia e compras comprometeram a instalação do MRPII. Precisa-se de comprometimento e disciplina para garantir a precisão nos dados do sistema, como dados de estoque e lista de materiais;

f) resistência: resistência dos funcionários à implementação por diferentes motivos pode levar a problemas na implantação;

g) busca por alternativas: por fim, os autores identificaram que em alguns casos a busca por alternativas ao sistema MRPII, durante a implementação do mesmo, pode consumir tempo e esforços para a implementação.

Ang, Sum e Yang (1994), através de uma survey, identificaram os principais problemas encontrados durante a implementação do MRP II. Os problemas foram divididos entre precisão de dados e problemas organizacionais. Os autores também estudaram a relação entre as características do sistema MRP II e a sua implementação, com aspectos como departamento responsável pelo sistema, nível de customização e tipos de hardware para suporte ao sistema. O Quadro 2.3 apresenta os resultados da pesquisa com os problemas em ordem decrescente de importância.

Quadro 2.3 - Problemas de precisão de dados e organizacionais na implementação do MRP II.

\begin{tabular}{ll}
\hline Problemas em precisão de dados & Problemas organizacionais \\
\hline Imprecisão nas previsões & Falta de conhecimento \\
\hline Imprecisão nos registros de inventário & Falta de treinamento \\
\hline
\end{tabular}


Quadro 2.3 - Problemas de precisão de dados e organizacionais na implementação do MRP II.

\begin{tabular}{ll}
\hline Problemas em precisão de dados & Problemas organizacionais \\
\hline $\begin{array}{l}\text { Imprecisão no cronograma mestre de } \\
\text { produção }\end{array}$ & Falta de comunicação \\
\hline $\begin{array}{l}\text { Imprecisão no controle de dados do chão } \\
\text { de fábrica }\end{array}$ & Falta de adequação do software \\
\hline Imprecisão no lead time de produção & Falta de suporte do vendedor \\
\hline Imprecisão no lead time de fornecimento & Falta de experiência na tecnologia \\
\hline Imprecisão na lista de materiais & Falta de conhecimento do fornecedor no \\
& MRP II \\
\hline Imprecisão & Alto custo do sistema \\
sequenciamento & Falta de suporte do marketing \\
\hline & Falta de metas claras \\
\hline & Falta de suporte da produção \\
\hline & Falta de adequação do hardware \\
\hline & Falta de suporte do supervisor \\
\hline & Falta de suporte da alta administração \\
\hline & Falta de suporte financeiro
\end{tabular}

Fonte: Ang, Sum e Yang (1994).

Em estudo posterior, Ang, Sum e Chung (1995) investigaram os fatores críticos de sucesso para implementação do MRP no contexto de Singapura. Inicialmente os autores realizaram uma revisão da literatura para encontrar os principais fatores relatados, depois realizaram uma survey a fim de ranquear os fatores de acordo com sua importância na percepção das empresas e funcionários.

As companhias que implantaram o sistema MRP relataram como principais benefícios melhoria na data de entrega, melhor programação de produção e melhor capacidade de atender a mudanças de volume e produto. Os fatores críticos de sucesso para implementação do MRP em ordem de importância, segundo a survey, foram os seguintes (ANG; SUM; CHUNG, 1995):
a) precisão e integridade dos dados;
b) suporte / compromisso da alta gerência;
C) metas e objetivos claros; 
d) treinamento e educação do pessoal sobre o MRP II;

e) motivação e comprometimento da equipe;

f) cooperação entre departamentos;

g) adequação de hardware e software;

h) comunicação entre departamentos;

i) visibilidade da implementação;

j) conhecimento do fornecedor do MRP II;

k) suporte do fornecedor;

l) expertise da empresa em tecnologia da informação;

m) nível de conhecimento do pessoal sobre MRP II antes da implementação.

Durmuşoğlu, Sümen e Yenen (1996) desenvolveram uma survey para estudar o caso turco de implementação de sistemas MRP/ MRP II. As dificuldades relatadas durante o estágio de implementação foram as seguintes: incompreensão da filosofia do MRP II, problemas de treinamento, problemas organizacionais e de força de trabalho, compatibilidade com o sistema existente, software adequado, tempo necessário para implementação, aquisição de dados, aquisição de hardware, falta de coordenação e suporte insuficiente do fornecedor.

Ang, Sum e Yeo (2002) realizaram um estudo de caso múltiplo para estudar os fatores críticos de sucesso para a implementação do MRP. Os autores consideraram sete os principais fatores: suporte da alta gestão (o mais citado), gestão efetiva de projeto, educação e treinamento, precisão dos dados, suporte amplo da companhia, adequação do hardware e software e suporte do fornecedor do software.

Petroni (2002) realizou um estudo dos fatores críticos para a implementação do MRP em pequenas e médias empresas. O autor relacionou estatisticamente fatores de implementação com fatores de desempenho esperados do sistema. Foi encontrado que precisão nos dados e um controle e planejamento formal de procedimentos contribuem mais para o aprimoramento do planejamento e gestão do inventário e melhoria da eficiência. Além disso, o suporte da alta gerência facilita o aprendizado e a implementação de novas tecnologias.

A partir dos anos 2000 com o desenvolvimento dos sistemas ERP cresceu o interesse dos pesquisadores em estudar o processo de implantação 
desse tipo de sistema. Bingi, Sharma e Godla (1999) em um estudo exploratório sobre questões críticas que afetam a implementação do ERP identificaram os seguintes dez fatores: comprometimento da alta gestão, reengenharia, integração, consultores de ERP, tempo de implementação, custo de implementação, fornecedores do ERP, selecionar funcionários para o projeto, treinamento e disposição dos funcionários.

Kumar, Maheshwari e Kumar (2002) realizaram uma survey para estudar o processo de adoção dos sistemas ERP para o caso canadense. Os pesquisadores identificaram dez benefícios esperados pela implementação, que são os seguintes: eliminação de redundância de dados, melhorar funcionalidade dos sistemas de informação, melhorar cumprimento de ordens, melhorar qualidade da informação, melhorar eficiência organizacional, resolver bugs de sistemas, aumento da integração de processos de negócios, padronizar processos de negócios, automatizar processos, melhorar planejamento e gestão de estoques.

Além disso os pesquisadores também identificaram os principais riscos para o sucesso da implementação, que são apresentados a seguir: aumentos dos custos durante implantação, disponibilidade de pessoal capacitado, alto grau de mudança organizacional, aceitação do usuário, capacidade de estrutura organizacional para a nova tecnologia, confiabilidade da rede, desafio em integração com outros sistemas, implementação incompleta por bugs, perda de controle com atualização do software (KUMAR; MAHESHWARI; KUMAR, 2002).

Ge e Voss (2009) conduziram um estudo geral sobre a aplicação do ERP na China. Os autores identificaram os seguintes fatores para o sucesso da implementação em nível global: envolvimento da alta gestão, trabalho em grupo, customização e comunicação. Além disso, identificaram fatores críticos de sucesso para o caso particular na China, sendo os seguintes: custo, suporte ao cliente por parte do fornecedor, idioma do sistema e padronização contábil.

Babaei, Gholami e Altafi (2015) fizeram um estudo para identificar os principais desafios na implementação do ERP para grandes organizações iranianas. Os autores concluíram que as barreiras organizacionais foram os maiores desafios para a implementação (falta de recursos humanos, falta de flexibilidade e falta de alinhamento dos processos com o ERP), em segundo 
lugar ficaram as barreiras tecnológicas e por fim as dos indivíduos (funcionários com resistência a mudança, falta de envolvimento da alta gestão).

Umble, Ronald e Umble (2003) analisaram os fatores críticos de sucesso e os procedimentos para a implementação do ERP com um trabalho combinado com um estudo de caso. O Quadro 2.4 apresenta os nove fatores críticos e os onze passos para implementação.

Quadro 2.4 - Fatores críticos de sucesso e passos de implementação do ERP. Fatores críticos para implementação Passos para a implementação

\begin{tabular}{ll}
$\begin{array}{l}\text { Entendimento claro dos objetivos } \\
\text { estratégicos }\end{array}$ & $\begin{array}{l}\text { Revisar o processo de pré- } \\
\text { implementação }\end{array}$ \\
\hline Comprometimento da alta gestão & Instalar e testar novos hardware \\
\hline Excelente gestão de projeto & Instalar e testar o software \\
\hline Gestão da mudança organizacional & Treinamento teórico \\
\hline Bom time de implementação & Treinamento prático \\
\hline Precisão dos dados & Estabelecer segurança e permissões \\
& necessárias \\
\hline Educação e treinamento & Garantir precisão e robustez dos dados \\
& e pontos de dados \\
\hline Foco em medidas de desempenho & Documentar políticas e procedimentos \\
\hline Implementação em diversas fábricas & Coloque toda a organização on-line, em \\
& uma transição total ou em uma \\
& abordagem por fases
\end{tabular}

Fonte: Umble, Ronald e Umble (2003).

Koh, Gunasekaran e Goodman (2011) realizaram um estudo e análise crítica sobre motivadores, barreiras e fatores críticos para a implementação do ERP II. Os autores realizaram um estudo exploratório para identificar essas questões de implementação através de entrevistas semiestruturadas. 0 Quadro 2.5 resume os resultados encontrados pelos pesquisadores relativos a motivadores e barreiras. 
Quadro 2.5 - Motivadores e barreiras para implementação do ERP II.

\section{Motivadores}

Empresa holística

Informação em tempo real

Poder de tomada de decisão

Redução de custo operacional

Eficiência de oferta/demanda
Barreiras

Inercia organizacional

BPM

Custo

Falta de entendimento dos negócios

Falta de entendimento global do negócio

Criação de valor Precisão/ qualidade dos dados

Otimização de processos lean Padrão dos dados

Integração de competências essenciais

parceiros

\begin{tabular}{ll}
\hline Responsividade à demanda & Choque cultural \\
\hline Melhoria na inovação & Escala da complexidade/ mudança
\end{tabular}

Fonte: Koh, Gunasekaran e Goodman (2011).

Já em relação aos fatores críticos de sucesso para a implementação do ERP II os autores dividiram em fatores comuns à implementação do ERP e fatores específicos do ERP II, também os separaram por fase da implementação. O Quadro 2.6 resume os resultados encontrados pelos pesquisadores.

Quadro 2.6 - Fatores críticos de sucesso para implementação do ERP e ERP II.

\begin{tabular}{ll}
\hline Fatores comuns ao ERP e ERP II & Fatores específicos do ERP II \\
\hline Visão clara & Eficiência operacional \\
\hline Planejamento robusto & Sistema empresarial eficiente \\
\hline Recursos organizacionais & Semelhança da cultura do parceiro \\
\hline Gestão de projeto & Objetivos comuns do parceiro \\
\hline Cultura proativa & Prioridades de parceiros semelhantes \\
\hline Precisão/ integridade dos dados & Suporte colaborativo do parceiro \\
\hline Treinamento & Confiança do parceiro \\
\hline & Gerenciamento de mudança de \\
& relacionamento \\
\hline & Consistência do padrão de dados
\end{tabular}

Fonte: Koh, Gunasekaran e Goodman (2011). 
Chang et al. (2012) aplicaram um modelo analítico hierárquico para predizer a possibilidade de sucesso na implementação de sistemas ERP. Para isso utilizaram uma técnica multicritério para tomada de decisão com relações de preferência linguística incompletas. Utilizaram como fatores que influenciam o sucesso da implementação os seguintes, baseados em pesquisas bibliográficas, consultas a especialistas e investigação do tema:

a) tempo de procedimento do projeto;

b) função do sistema de informação;

c) cooperação do usuário;

d) grau de apoio do gerente sênior;

e) coordenação;

f) organizacional;

g) custo.

Erkayman (2018) por meio de uma pesquisa ação introduziu uma abordagem de transição para a produção JIT através da implementação do ERP. O autor concluiu que as tecnologias associadas ao ERP podem ajudar na transição para a produção enxuta. Além disso, o autor identificou melhorias feita na produção usando cálculos do MRP em tempo real.

Outros autores também trabalharam com o tema de implementação dos sistemas ERP. Parr e Shanks (2000) propuseram um modelo de projeto por fases para a implementação do ERP, em que detalham as etapas da implantação com os fatores críticos de acordo com a fase do projeto. Guanghui, Chun-qing e Yun-xiu (2006) também investigaram os fatores mais importantes para o sucesso da implementação em cada fase do projeto.

Um framework integrativo baseado em revisão bibliográfica dos fatores e elementos essenciais para a implementação do ERP foi proposto por AlMudimigh, Zairi e Al-Mashari (2001). Maditinos, Chatzoudes e Tsairidis (2011) investigaram quais fatores possuem mais efeito sobre a implementação do ERP através de uma survey com análise estatística dos resultados. No estudo, que foi conduzido na Grécia, os autores destacaram nos resultados a importância do suporte de consultores externos e transferência de conhecimento.

Mabert, Soni e Venkataramanan (2003) através de uma survey com análise estatística estudaram como gerir o processo de implementação do ERP. Para isso identificaram variáveis de planejamento, de implementação e 
de decisão estratégica e avaliaram o peso delas na implementação, concluíram que as variáveis de planejamento foram muito significantes no modelo, o que indicava que o processo de planejamento é muito importante para o sucesso da implementação. Além disso, também identificaram que customizações elevam muito os custos e prazo do projeto e que, contra intuitivamente, comunicação pode elevar os custos, pois segundo os autores, pode significar maiores revisões do projeto e customizações requeridas.

Já no trabalho de Yusuf, Gunasekaran e Abthorpe (2004) os autores realizam um estudo de caso aprofundado da implantação do ERP na empresa Rolls-Royce em que relatam todo o histórico da companhia antes, durante e depois da implementação do sistema SAP. Foram identificadas as principais dificuldades para implementação e as atividades mais importantes para o sucesso da implementação.

Com relação a implementação de sistemas de planejamento e controle da produção baseados na produção enxuta ou a aplicação de ferramentas Lean também existem diversos estudos. Muitas das barreiras, dificuldades e fatores críticos para o sucesso da implementação são compartilhadas entre os sistemas MRP/ ERP e a produção enxuta.

Salonitis e Tsinopoulos (2016) dividiram as barreiras para a implementação do Lean em quatro categorias conforme a seguir:

a) barreias da alta gestão

- baixo comprometimento devido à pouco conhecimento e entendimento, pouca convicção de melhoria e inércia a mudança;

- comprometimento por tempo insuficiente;

b) barreiras da força de trabalho

- baixo comprometimento devido à medo de cortes em postos de trabalho, pouco conhecimento do método, inércia a mudança e falta de comunicação;

c) barreiras financeiras

- necessidade de altos investimentos, custos;

d) outras barreiras

- distrações ou diminuição do ritmo devido a outros projetos e problemas;

- aplicação em diferentes plantas; 
- dificuldade de estimar os benefícios.

Além das barreiras Salonitis e Tsinopoulos (2016) também enumeraram os principais motivos para a decisão de implantação do lean manufacturing e os fatores críticos de sucesso para a implementação. A seguir são enumerados os motivadores e fatores.

São motivadores para implantação do Lean identificados pelos autores os seguintes (SALONITIS; TSINOPOULOS, 2016):
a) aumentar o market share;
b) aumentar a flexibilidade;
c) necessidade de sobrevivência frente restrições internas;
d) desenvolvimento de indicadores chave de desempenho;
e) aplicar as melhores práticas de mercado;
f) parte de melhorias contínuas da organização;
g) focar nos clientes;
h) exigência/ motivação pelos clientes;
i) exigência da matriz.

São fatores críticos de sucesso para a implementação do Lean identificados pelos autores os seguintes (Salonitis; Tsinopoulos, 2016):

a) cultura organizacional e senso de dono;

b) desenvolvimento de prontidão organizacional;

c) compromisso e capacidade de gestão;

d) fornecer recursos adequados para apoiar mudanças;

e) suporte de consultores externo no primeiro momento;

f) comunicação e engajamento eficazes;

g) abordagem estratégica para melhorias;

h) trabalho em equipe e pensamento conjunto de sistemas;

i) percepção para definir prazos realistas para a mudança e fazer uso efetivo de compromissos e entusiasmo pela mudança.

Jadhav, Mantha e Rane (2014) identificaram vinte e quatro barreiras para a correta implementação do lean através de uma revisão bibliográfica sistemática. No estudo os autores analisaram as barreiras e concluíram que além dos problemas de ordem técnica também podem ocorrer problemas de gestão com líderes, trabalhadores, recursos e cultura organizacional.

Abu et al. (2019) através de uma revisão da literatura investigaram questões da implementação do lean, identificando barreiras, motivação para 
implementação, desafios e ferramentas aplicadas. Com isso realizaram uma survey a fim de analisar estatisticamente se as hipóteses identificadas na literatura eram significativas na visão as empresas e pessoas que implementaram o lean.

Foram identificados os seguintes dez motivos para aplicação do lean (Abu et al., 2019):
a) para aumentar eficiência;
b) para melhorar utilização do espaço;
c) para limpar e organizar o local de trabalho;
d) para reduzir custos de produção;
e) para melhorar a qualidade;
f) para facilitar a produção Just-in-time;
g) para eliminar desperdícios;
h) para melhorar a comunicação de informações;
i) para aumentar a satisfação dos clientes;
j) para resolver problemas.

Com relação as barreiras na implementação os autores identificaram as seguintes (Abu et al., 2019):
a) resistência a mudança dos gestores de médio escalão;
b) resistência a mudança dos trabalhadores;
c) o lean é de difícil implementação;
d) o lean é pouco efetivo;
e) o lean não se encaixa na cultura organizacional;
f) falta de conhecimento de implementação;
g) falta de conhecimento sobre o lean;
h) falta de conhecimento dos benefícios;
i) falta de tempo;
j) falta de recursos financeiros;
k) falta de recursos humanos.

Já como desafios durante a implementação foram listados os seguintes (Abu et al., 2019):
a) falta de comprometimentos dos funcionários;
b) falta de interesse e suporte dos gestores;
c) dificuldades para implementar;
d) lean visto como "tendência da moda"; 

e) falta de sustentabilidade, volta aos antigos métodos;
f) falta de conhecimento técnico;
g) falta de treinamento;
h) desconhecimento dos benefícios tangíveis;
i) falta de tempo;
j) falta de recursos financeiros;
k) falta de recursos humanos.

\subsection{CONCLUSÃO DO CAPÍTULO}

Como visto ao longo do capítulo a nova dinâmica nos mercados fez a volatilidade e a incerteza aumentarem, cenário esse conhecido também pelo acrônimo VUCA. Com isso as cadeias ágeis e demand driven que apresentam uma série de características relatadas ao longo do texto tem conseguido se destacar e vem ganhando atenção por parte das empresas.

Esse ambiente tem despertado o interesse por novas soluções para gestão da produção que possam operacionalizar essa abordagem. Com isso foram estudas as características das cadeias de suprimentos ágeis e demand driven, na seção 2.1, e questões de implementação, na seção 2.2, de métodos conhecidos e bem disseminados que foram base para 0 desenvolvimento da teoria do DDMRP a fim de identificar potenciais motivações, barreiras e fatores críticos de sucesso para a implementação do DDMRP.

Com isso, pode-se concluir esse capítulo com os fatores de implementação gerais selecionados para serem constructos do questionário para a survey. Os fatores gerais foram originados da revisão de implementação de outros métodos de gestão da produção e da teoria de cadeias de suprimentos. A seguir são apresentados os fatores selecionados com as referências e um breve comentário justificando a seleção.

a) motivações para implementação:

$\checkmark$ Redução de lead time: proporciona respostas mais ágeis, reduzindo tempo de atendimento. É um dos atributos das cadeias ágeis e demand driven (ROMANO, 2000; AYERS; MALMBERG, 2002; AGARWAL et al., 2006; PRAJOGO; SOHAL, 
2006; VOLTOLINI, 2010; NAIM; GOSLING, 2011; KISPERSKAMORON; de HAAN, 2011);

$\checkmark$ Aumentar agilidade e responsividade: essa motivação advém dos melhores resultados que esses atributos proporcionam em um cenário VUCA (ECKSTEIN et al., 2015; DENNING, 2018);

$\checkmark$ Orientação à demanda: por ser difícil prever a demanda, buscase tomar decisões de produção se orientado pela demanda (AYERS; MALMBERG, 2002; VOLTOLINI, 2010; YUSUF et al., 2014);

$\checkmark$ Aplicar melhores práticas de mercado: muitas empresas buscam aplicar práticas que estão em alta no mercado, como por exemplo o Lean (SALONITIS; TSINOPOULOS, 2016).

b) barreiras para implementação:

$\checkmark$ Falta de conhecimento do método: barreira frequentemente citada na implementação de métodos de PCP (ANG; SUM; YANG, 1994; SALONITIS; TSINOPOULOS, 2016; ABU et al., 2019);

$\checkmark$ Falta de precisão nos dados: barreira citada por autores na implementação do MRP e ERP (WILSON; DESMOND; ROBERTS, 1994; ANG; SUM; YANG, 1994; KOH; GUNASEKARAN; GOODMAN, 2011);

$\checkmark$ Falta de suporte da alta gerência: barreira frequentemente citada na implementação de métodos de PCP (ANG; SUM; YANG, 1994; WILSON; DESMOND; ROBERTS, 1994; BABAEI; GHOLAMI; ALTAFI, 2015; SALONITIS; TSINOPOULOS, 2016);

$\checkmark$ Falta de suporte do fornecedor do sistema: barreira citada na implementação do MRP (ANG; SUM; YANG, 1994; DURMUŞOĞLU; SÜMEN; YENEN, 1996; BINGI; SHARMA; GODLA, 1999);

$\checkmark$ Falta de comprometimento dos funcionários: barreira citada na implementação de métodos de PCP (WILSON; DESMOND; ROBERTS, 1994; SALONITIS; TSINOPOULOS, 2016; ABU et al., 2019);

$\checkmark$ Falta de treinamento: fator frequentemente apontado como barreira (ANG; SUM; YANG, 1994; DURMUŞOĞLU; SÜMEN; 
YENEN, 1996; BINGI; SHARMA; GODLA, 1999; ABU et al., 2019);

$\checkmark$ Falta de recursos humanos: barreira associada tanto a implementação do ERP quanto do Lean (BABAEI; GHOLAMI; ALTAFI, 2015; ABU et al., 2019);

$\checkmark$ Falta de tempo disponível: barreiras que afeta a implementação de diferentes sistemas de PCP (DURMUŞOĞLU; SÜMEN; YENEN, 1996; BINGI; SHARMA; GODLA, 1999, SALONITIS; TSINOPOULOS, 2016; ABU et al., 2019);

$\checkmark$ Falta de apoio de consultores externos: pode se tornar uma barreira quando associado a outros fatores (BINGI; SHARMA; GODLA, 1999);

$\checkmark$ Falta de compartilhamento de informações entre departamentos: a falta de comunicação e troca de informações é apontada como uma barreira ao bom desenvolvimento da implementação (ANG; SUM; YANG, 1994);

$\checkmark$ Falta de prazos e metas claras: barreira que afeta o andamento do processo de implementação (ANG; SUM; YANG, 1994; KOH, GUNASEKARAN; GOODMAN, 2011);

$\checkmark$ Incompatibilidade com outros sistemas da empresa: barreira que afeta a integração com sistemas já existentes (DURMUŞOĞLU; SÜMEN; YENEN, 1996)

$\checkmark$ Choque cultural: barreira que pode acorrer por mudança drástica na cultura organizacional (KOH; GUNASEKARAN; GOODMAN, 2011; ABU et al., 2019);

$\checkmark$ Customizações requisitadas no sistema: podem aumentar os custos e a complexidade (WILSON; DESMOND; ROBERTS, 1994; ANG; SUM; YANG, 1994; MABERT; SONI; VENKATARAMANAN, 2003);

$\checkmark$ Custo elevado: alto custo para implementação se configura como barreira para diversos sistemas de gestão (ANG; SUM; YANG, 1994; BINGI; SHARMA; GODLA, 1999; $\mathrm{KOH;}$ GUNASEKARAN; GOODMAN, 2011; SALONITIS; TSINOPOULOS, 2016); 
$\checkmark$ Complexidade do projeto / mudança: barreira associada a implementação de sistemas que necessitem de grandes projetos (KOH; GUNASEKARAN; GOODMAN, 2011);

$\checkmark$ Resistência a mudança: dificulta o processo de implementação (WILSON; DESMOND; ROBERTS, 1994; BABAEI; GHOLAMI; ALTAFI, 2015; ABU et al., 2019).

c) fatores críticos de sucesso para implementação:

$\checkmark$ Apoio da alta gerência: fator citado por autores que pesquisaram sobre sucesso de implementação de métodos de planejamento e controle de produção (ANG; SUM; CHUNG, 1995; ANG; SUM; YEO, 2002; PETRONI, 2002; UMBLE; RONALD; UMBLE, 2003; GE; VOSS, 2009);

$\checkmark$ Treinamento e educação: fator citado como importante para o sucesso da implementação de soluções como MRP e ERP (ANG; SUM; CHUNG, 1995; ANG; SUM; YEO, 2002; BINGI; SHARMA; GODLA, 1999; UMBLE; RONALD; UMBLE, 2003; KOH; GUNASEKARAN; GOODMAN, 2011);

$\checkmark$ Planejamento e gestão de projeto: fator importante para o controle e acompanhamento da implementação (ANG; SUM; YEO, 2002; UMBLE; RONALD; UMBLE, 2003; $\mathrm{KOH}$; GUNASEKARAN; GOODMAN, 2011);

$\checkmark$ Suporte de consultores externos: fator citado como importante para apoio durante o processo de implementação (BINGI; SHARMA; GODLA, 1999; MADITINOS; CHATZOUDES; TSAIRIDIS, 2011; SALONITIS; TSINOPOULOS, 2016);

$\checkmark$ Suporte do fornecedor do sistema: importante que o fornecedor do sistema selecionado dê suporte adequado durante a implementação (ANG; SUM; CHUNG, 1995; SHARMA; GODLA, 1999; ANG; SUM; YEO, 2002; BINGI; GE; VOSS, 2009);

$\checkmark$ Disponibilidade de recursos: é importante a disponibilização de recursos adequados (KOH; GUNASEKARAN; GOODMAN, 2011; SALONITIS; TSINOPOULOS, 2016);

$\checkmark$ Precisão e integridade dos dados: muito importante para abastecer o sistema com premissas corretas (ANG; SUM; 
CHUNG, 1995; ANG; SUM; YEO, 2002; PETRONI, 2002; UMBLE; RONALD; UMBLE, 2003; KOH; GUNASEKARAN; GOODMAN, 2011);

$\checkmark$ Adequação do hardware e software: citado como fator relevante para suportar as novas tecnologias (ANG; SUM; CHUNG, 1995 ANG; SUM; YEO, 2002);

$\checkmark$ Metas e objetivos claros: é importante que as metas e objetivos estejam claros e alinhados entre os stakeholders (ANG; SUM; CHUNG, 1995; UMBLE; RONALD; UMBLE, 2003; $\mathrm{KOH}$; GUNASEKARAN; GOODMAN, 2011);

$\checkmark$ Motivação e comprometimento da equipe: fator apontado como importante para mobilização dos colaboradores (ANG; SUM; CHUNG, 1995; SALONITIS; TSINOPOULOS, 2016);

$\checkmark$ Comunicação e engajamento: fator importante para divulgar benefícios e diminuir resistências (ANG; SUM; CHUNG, 1995; GE; VOSS, 2009; SALONITIS; TSINOPOULOS, 2016);

$\checkmark$ Conhecimento técnico aprofundado do método: citado como fator importante o conhecimento prévio do método (ANG; SUM; CHUNG, 1995), além disso a falta de conhecimento é frequentemente descrita como barreira;

$\checkmark$ Compartilhamento de informações: a comunicação e troca de informações entre os departamentos é um fator descrito como importante para a implementação (ANG; SUM; CHUNG, 1995);

$\checkmark$ Cultura organizacional proativa: fator importante para uma boa gestão da mudança, o sucesso é baseado na prontidão das pessoas em agir (KOH; GUNASEKARAN; GOODMAN, 2011; SALONITIS; TSINOPOULOS, 2016). 


\section{CAPÍTULO 3 - INTRODUÇÃO DO DDMRP E REVISÃO BIBLIOGRÁFICA DO TEMA}

\subsection{INTRODUÇÃO}

Dentro desse contexto das cadeias de suprimentos, apresentado no capítulo anterior, os autores Carol Ptak e Chad Smith desenvolveram o DDMRP no começo do século XXI e o formalizaram e apresentaram na terceira edição do livro Orlicky's Material Requirements Planning no ano de 2011. Posteriormente consolidaram a teoria do DDMRP no livro "Demand Driven Material Requirements Planning" (PTAK; SMITH, 2011; PTAK; SMITH, 2016).

Os métodos de gerenciamento de materiais atuais têm apresentado resultados não satisfatórios para vários casos devido as incertezas de mercado e processos. Então, os autores desenvolveram o DDMRP e o apresentaram como uma solução para superar essas dificuldades enfrentadas pelos métodos tradicionais em uso (PTAK; SMITH, 2011; PTAK; SMITH, 2016; MICLO, 2016).

O objetivo desse capítulo é apresentar o método DDMRP conforme definido pelos autores originais, realizar uma revisão da literatura acadêmicocientífica publicada sobre o tema e concluir o capítulo com os aspectos de implementação específicos do DDMRP propostos para o questionário da survey.

\subsection{DEFINIÇÃO CONCEITUAL DO DDMRP}

\subsubsection{As Raízes e Princípios do DDMRP}

O desenvolvimento do método partiu do princípio que existem boas práticas tanto no MRP quanto no Lean, porém, a combinação de ambos pode levar a conflitos. O DDMRP é baseado em cinco metodologias: MRP, DRP, Lean, TOC e Six Sigma, para completar o método e integrar os elementos dessas teorias de forma harmônica, solucionando esses conflitos, o DDMRP 
inclui inovações. A Figura 3.1 ilustra esses métodos como forma de pilares para o DDMRP.

Figura 3.1 - Pilares fundamentais do DDMRP.

\section{Demand Driven MRP (DDMRP)}

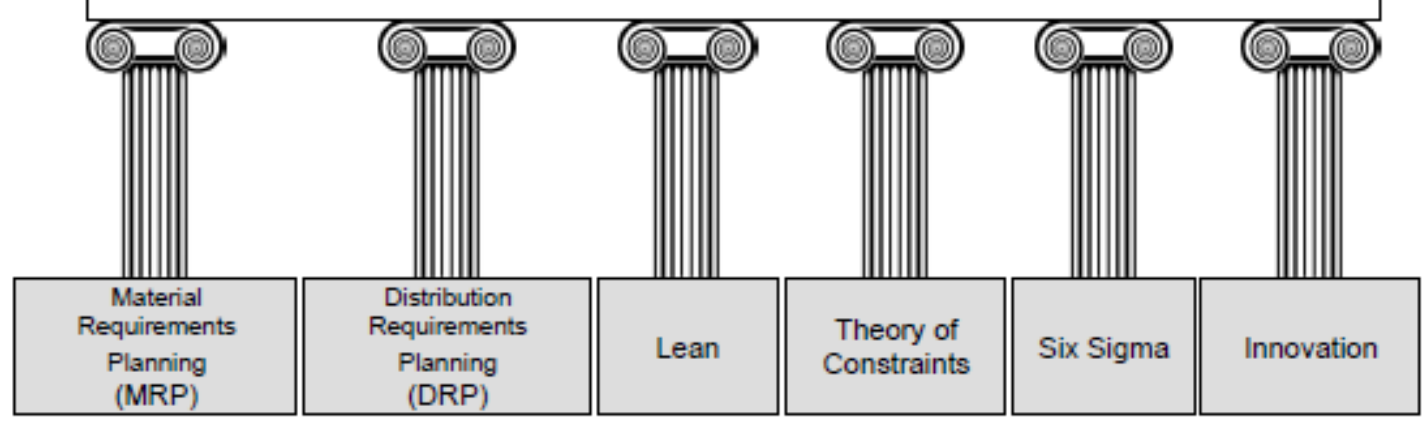

Fonte: Ptak e Smith (2016).

O DDMRP utiliza roteiro e a lista de materiais (BOM - Bill of Materials - Estrutura do produto) com buffers localizados em pontos específicos dessa estrutura. Esses buffers representam pontos de desacoplamento para absorver a variabilidade e a incerteza; eles são estrategicamente posicionados. O fluxo é então puxado entre esses diferentes buffers. Entre as referências da lista de materiais (sem os buffers) a geração de ordens de produção é feita pelo MRP (MICLO, 2016).

Para atingir os objetivos de capital de giro e materiais em processo a implementação do DDMRP segue três passos bem definidos: posicionamento dos buffers, proteção e puxar o fluxo. Esses três passos incluem os cinco componentes detalhados a seguir (PTAK; SMITH, 2016, MICLO, 2016):

a) posicionamento estratégico do inventário: o objetivo é definir em quais pontos colocar os pontos de desacoplamento, que são os buffers dos materiais mais sensíveis a variabilidades e incertezas;

b) nível e perfil dos buffers: à medida que são estabelecidos os pontos de desacoplamento os buffers são dimensionados para lidar com as incertezas e a demanda;

c) ajuste Dinâmico: com as variabilidades de sazonalidade, evolução da demanda, produção de lançamento e descontinuidade de produtos os buffers devem ser ajustados 
dinamicamente, de modo que seu dimensionamento seja reajustado a nova fase do produto;

d) planejamento Demand Driven: com esses três passos o ambiente do DDMRP está definido, agora é possível planejar o fluxo. O Planejamento baseado na demanda permite que as prioridades sejam determinadas e as ordens de suprimento sejam geradas;

e) execução visual colaborativa: o componente final ajuda no gerenciamento na rotina diária com problemas regulares. Esse componente gerencia o fluxo com diferentes tipos de alertas e prioriza os pedidos para garantir a entrega do cliente no prazo.

A Figura 3.2 sintetiza esse raciocínio de implementação do DDMRP.

Figura 3.2 - Os cinco componentes de implementação do DDMRP.

\section{Demand Driven Material Requirements Planning}

\begin{tabular}{|c|c|c|c|c|}
\hline $\begin{array}{c}\text { Strategic } \\
\text { Inventory } \\
\text { Positioning }\end{array}$ & $\begin{array}{c}\text { Buffer Profiles } \\
\text { and Levels }\end{array}$ & $\begin{array}{c}\text { Dynamic } \\
\text { Adjustments }\end{array}$ & $\begin{array}{c}\text { Demand Driven } \\
\text { Planning }\end{array}$ & $\begin{array}{c}\text { Visible and } \\
\text { Collaborative } \\
\text { Execution }\end{array}$ \\
\hline Position & Protect & \\
\hline
\end{tabular}

Fonte: Ptak e Smith (2016).

Na sequência serão explorados de forma resumida cada um dos componentes de implementação do DDMRP.

\subsubsection{Posicionamento Estratégico do Inventário}

O primeiro componente para implementação do DDMRP se trata do posicionamento estratégico de inventário. Nessa etapa a prioridade é definir onde posicionar e não quanto, que será definido na próxima etapa.

O objetivo desses buffers é estabelecer pontos de desacoplamento que irão atuar para eliminar ou reduzir os efeitos das fontes de variabilidade e a sua principal consequência, o efeito chicote (Bullwhip Effect). Para responder 
à questão "Onde posicionar?" seis fatores fundamentais devem ser analisados: tempo de tolerância do cliente, lead time de potencial de mercado, horizonte de visibilidade de pedidos de vendas, variabilidades externas, flexibilidade e alavancagem de estoque e proteção de operação crítica.

A definição desses seis critérios segundo os autores do método é apresentada a seguir (PTAK; SMITH, 2016):

a) tempo de tolerância do cliente ("customer tolerance time"): quantidade de tempo que potenciais clientes estão dispostos a aguardar pela entrega do produto ou serviço;

b) lead time de potencial de mercado ("Market potential lead time"): esse é o lead time que permite um aumento de preço ou a captação de novos negócios por meio de canais de novos clientes ou já existentes;

c) horizonte de visibilidade de pedidos de vendas ("Sales order visibility horizon"): é o período de tempo em que normalmente nos tornamos conscientes dos pedidos de vendas ou da demanda dependente real;

d) variabilidades externas ("External variability"): existem dois tipos, variabilidade de demanda que podem sobrecarregar os recursos produtivos, e a variabilidade de fornecimento que pode provocar interrupções no fornecimento e abastecimento;

e) flexibilidade e alavancagem de estoque ("Inventory leverage and flexibility"): os locais na estrutura da lista de materiais (Bill of Material) ou na rede de distribuição que permite uma empresa com as opções mais disponíveis, bem como a melhor compactação de tempo de processamento para atender às necessidades de negócios;

f) proteção de operação crítica ("Critical operation protection"): são as operações que possuem capacidade limitada ou onde a qualidade pode ser comprometida se houver interrupções ou então locais em que a variabilidade tende a acumular ou ser amplificada.

A respeito das fontes de variabilidade mencionadas anteriormente elas são identificadas como quatro segundo a teoria do DDMRP. 
a) variabilidade de suprimentos: em termos de tempo e quantidade;

b) variabilidade de demanda: em termos de tempo e quantidade;

c) variabilidade operacional: em termos de gerenciamento de processos, variação de tempo de operações e problemas de qualidade;

d) variabilidade de gerenciamento: em termos da estratégia utilizada para gerenciar o sistema e a maneira que ela é explicada as equipes de trabalho.

No DDMRP apenas para itens estratégicos são criados buffers. Um item pode ser considerado estratégico por uma série de fatores, ter uma grande compressão de lead time, ser um produto estratégico para venda, ser obrigatório ter o produto disponível sob contrato, ou ter retorno sobre investimento (ROI - Return on Investment) positivo quando o item passa a possuir um buffer (PTAK; SMITH, 2016, MICLO, 2016):

A partir desse conceito pode-se comparar o DDMRP com o MRP tradicional onde não há pontos de desacoplamento, ou ainda, com o sistema kanban onde tudo é desacoplado. No DDMRP apenas os itens com buffers possuem pontos de desacoplamento (MICLO, 2016).

Um conceito importante introduzido pelo DDMRP que é relevante para o estabelecimento dos pontos de desacoplamento é o lead time de desacoplamento - Decoupling Lead Time (DLT), também conhecido como Actively-Synchronized Lead Time (ASRLT). O DLT pode ser descrito como o mais longo lead time desprotegido na lista de materiais - BOM. O caminho mais longo desprotegido em uma BOM é a maior soma de lead times de produção a outro buffer ou ao nível mais baixo da BOM (PTAK; SMITH, 2016, MICLO, 2016).

Esse conceito pode ser ilustrado pela Figura 3.3 a seguir. Ela representa a lista de materiais com o respectivo lead time dos subcomponentes nos círculos na imagem a esquerda. Já na imagem a direita são estabelecidos os posicionamentos dos buffers do DDMRP. 
Figura 3.3 - Lista de componentes do produto FPD com posicionamento de buffers do DDMRP.
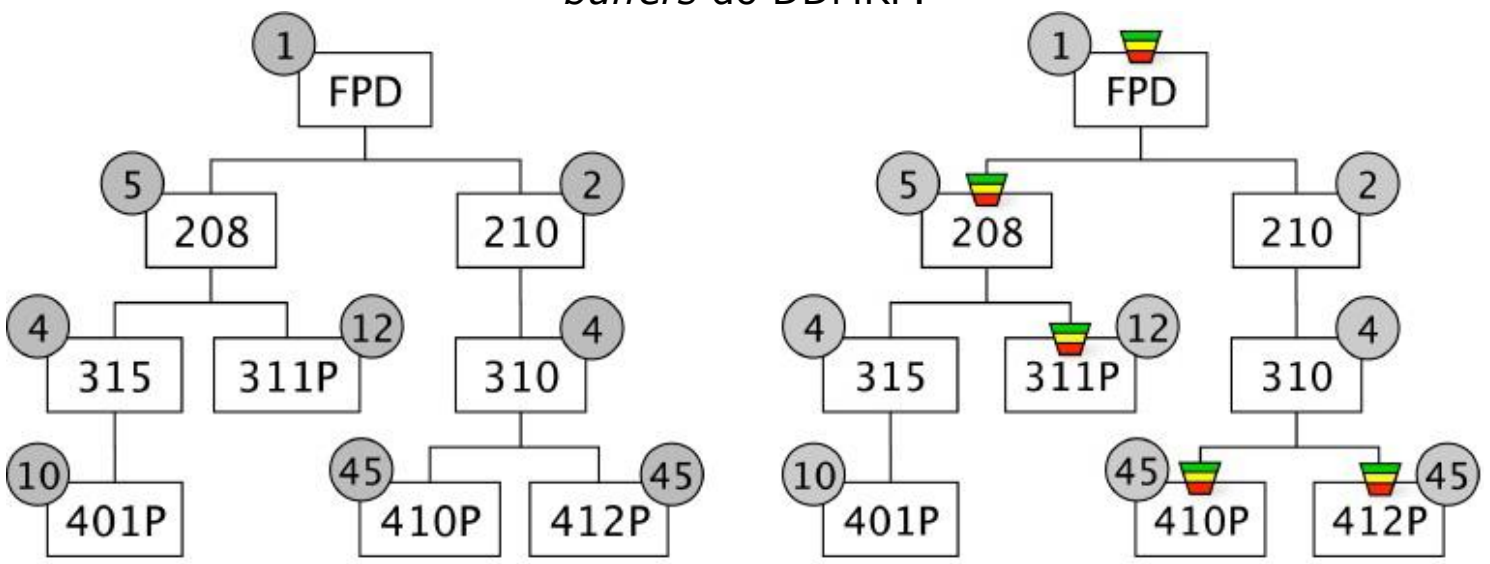

Fonte: Ptak e Smith (2016).

Inicialmente o DLT para o produto FPD é de 52 dias (45 dias para 410P ou 412 P, mais 4 dias para 310, mais 2 dias para 210 mais 1 dia para FPD). Após o estabelecimento dos buffers de desacoplamento temos esse tempo reduzido para 7 dias (4 dias para 310, mais 2 dias para 210, mais 1 dia para FPD).

Pela mesma lógica pode-se calcular o DLT para o subcomponente 208. O resultado é 19 dias (10 dias para 401P, mais 4 dias para 315, mais 5 dias para 208). Se um ponto de desacoplamento for introduzido no componente $401 \mathrm{P}$ esse tempo de 19 dias reduziria para 9 dias, importante observar que o subcomponente 311P já possui um buffer estrategicamente posicionado.

\subsubsection{Nível e perfil de buffers}

Após os buffers serem posicionados como abordado na seção 3.2 .20 próximo passo é dimensioná-los. Um buffer é composto por três zonas visuais: verde, amarelo e vermelho. Essas diferentes zonas estão definidas conforme a Figura 3.4. 
Figura 3.4 - Definição das zonas do buffer do DDMRP.

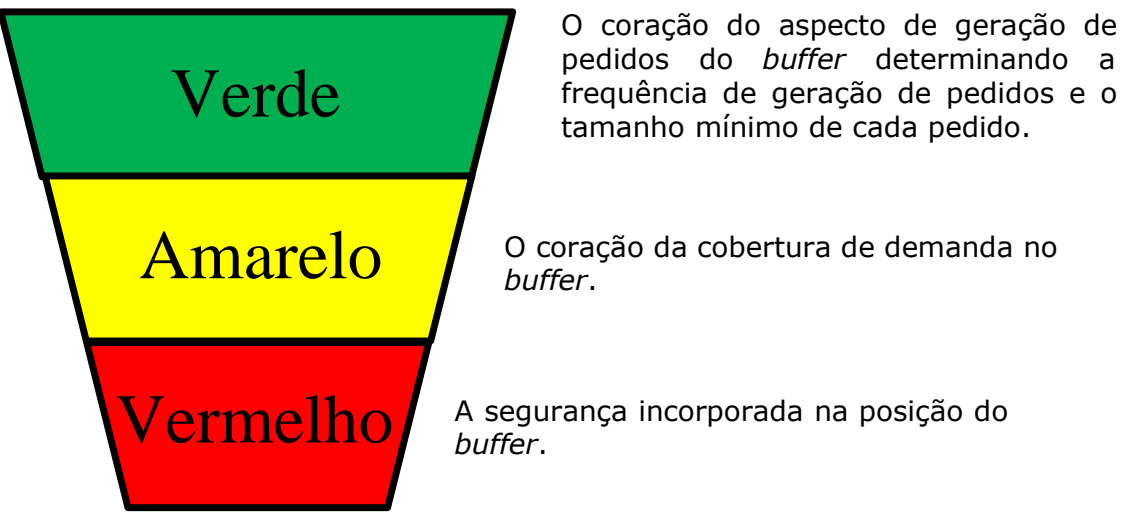

Fonte: Ptak e Smith (2016).

O próximo passo é definir como dimensionar cada umas dessas três zonas. Para tal quatro parâmetros dos componentes são necessários, assim como, três parâmetros do perfil do buffer. Os quatro parâmetros dos componentes necessários são descritos a seguir (PTAK; SMITH, 2016, MICLO, 2016):

a) local (Location): para componentes distribuídos esse parâmetro terá impacto no dimensionamento do buffer;

b) lead time de desacoplamento (Decoupling Lead Time): de acordo com o lead time do componente, os perfis da zona serão dimensionados de maneira diferente. Dependendo se uma peça tem um lead time curto ou longo, seu comportamento e gerenciamento serão adaptados;

c) quantidade mínima de encomenda (MOQ - Minimum Order Quantity): se houver uma quantidade mínima de encomenda significativa os meios de gerar ordens de fornecimento também devem ser adaptados (isso terá impactos na zona verde);

d) uso diário médio (ADU - Average Daily Usage): todas as zonas do buffer serão proporcionais ao consumo diário.

Então, os componentes serão atribuídos a perfis de buffers. Esses perfis de buffer serão organizados dependendo dos 3 parâmetros do perfil de buffer.

a) tipo de item: os componentes devem ser primeiramente agrupados de acordo com o tipo: comprados, produzidos ou distribuídos; 
b) categoria de lead time de desacoplamento (Categoria de DLT): o lead time é determinado por categorias como: curto, médio ou longo (pode ser melhor detalhado);

c) categoria de variabilidade: a variabilidade também é determinada em categorias, como: baixa, média e alta variabilidade (também pode ser melhor detalhada).

O destaque é que os dois últimos parâmetros não são matematicamente definidos, eles devem ser definidos a partir da experiência (ou pelo senso comum) com algumas regras.

O próximo passo após a coleta de todos esses dados é dimensionar os buffers. A primeira zona a ser calculada é a amarela, de acordo com a Equação 1, para fins de manter a nomenclatura original do método os termos em inglês serão mantidos.

$$
\text { Yellow zone }=A D U \times D L T
$$

Após essa definição a próxima zona e ser dimensionada é a vermelha, ela é composta pela "Red zone base" e pôr a "Red zone safety". A primeira parte é baseada no lead time, já a segunda parte é baseada na variabilidade. As Equações 2, 3 e 4 expressam os cálculos.

$$
\begin{array}{ll}
\text { Red zone base }=\text { Yellow zone } x \text { Lead Time factor } & \text { (Equação 2) } \\
\text { Red zone safety }=\text { Red zone base } x \text { Variability Factor } & \text { (Equação 3) } \\
\text { Red zone }=\text { Red zone base }+ \text { red zone safety } & \text { (Equação 4) }
\end{array}
$$

A zona vermelha do estoque representa a absorção de emergência de variações repentinas, como por exemplo a adoção de estoques de segurança no MRP II (MICLO, 2016).

É entendido dentro do contexto de planejamento de produção que quanto mais alto o nível de serviço desejado maior deve ser o estoque de segurança. Portanto, controlando o investimento nesse tipo de estoque podese controlar o nível de serviço desejado (PTAK; SMITH, 2011).

Os autores do método sugerem fatores numéricos para serem usados com as categorias de lead time e variabilidade. Esses fatores são apresentados no Quadro 3.1 a seguir. 
Quadro 3.1 - Fatores de Lead Time e Variabilidade sugeridos.

\begin{tabular}{ll}
\hline Red Zone Base & Lead Time Factor \\
\hline Lead Time Longo & $20-40 \%$ ADU x DLT \\
\hline Lead Time Médio & $41-60 \%$ ADU x DLT \\
\hline Lead Time Curto & $61-100 \%$ ADU x DLT \\
\hline Red Zone Safety & Variability Factor \\
\hline Alta Variabilidade & $61-100 \%$ Red Zone Base \\
\hline Média Variabilidade & $41-60 \%$ Red Zone Base \\
\hline Baixa Variabilidade & $20-40 \%$ Red Zone Base
\end{tabular}

Fonte: Ptak e Smith (2016).

Por último é definido o cálculo para a zona verde do buffer. Existem três maneiras de dimensionar a zona verde, essas diferentes maneiras são apresentadas pelas Equações 5, 6 e 7.

Green Zone $=$ Yellow zone $x$ Lead Time Factor

(Equação 5)

Green Zone $=M O Q$

(Equação 6)

Green Zone $=A D U \times$ "ciclo de pedido imposto ou desejado em dias" (Equação 7)

O "Lead Time Factor" para a zona verde pode ser diferente do da zona vermelha. A maneira de calcular a zona verde pode ser escolhida pela empresa de acordo com a conveniência, mas em geral se utiliza o maior valor entre os três.

A Figura 3.5 apresenta a ideia das equações "Top of" que são usadas para expressar de maneira detalhada o buffer do DDMRP. A seguir são apresentadas as Equações 8, 9 e 10.

$$
\begin{aligned}
& \text { Top of Red }(T O R)=\text { Red Zone } \\
& \text { Top of Yellow }(T O Y)=\text { TOR + Yellow Zone } \\
& \text { Top of Green }(T O G)=\text { TOY + Green Zone }
\end{aligned}
$$
(Equação 10) 
Figura 3.5 - Zonas "Top of" do buffer DDMRP.

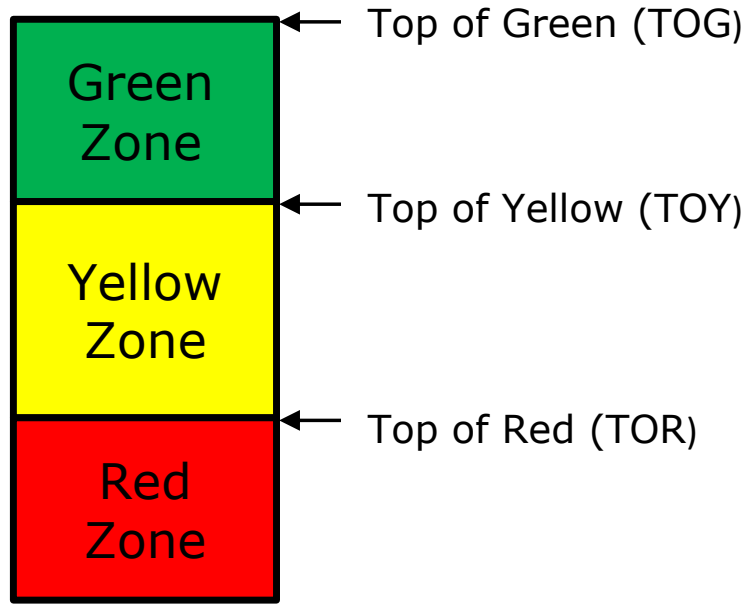

Fonte: Ptak e Smith (2016).

Portanto, TOG é a soma de todas as zonas de estoque do buffer do DDMRP. Esses temas serão ilustrados no tópico 3.2.4 a seguir.

\subsubsection{Análise com exemplos do posicionamento, dimensionamento e ROI}

O Quadro 3.2 a seguir exemplifica o dimensionamento de dois buffers segundo a teoria do DDMRP. Para esses dois itens o "lead time factor" é de $25 \%$ e o "variability factor" é de $50 \%$. Para ambos itens a zona verde é calculada pela Equação 5, pois se trata do maior valor. Para o item FPA o TOG é de 8.125 e para FPC o valor de TOG é 11.213 .

Quadro 3.2 - Exemplos de dimensionamento de buffer.

\begin{tabular}{|c|c|c|c|}
\hline \multicolumn{2}{|l|}{ FPA } & \multicolumn{2}{|l|}{ FPC } \\
\hline \multirow[t]{4}{*}{ Green Zone } & 1250 & \multirow[t]{4}{*}{ Green Zone } & 1725 \\
\hline & LT Factor: $1250(5000 \times 0,25)$ & & LT Factor: $1725(6900 \times 0,25)$ \\
\hline & Minimum Order Quantity: 250 & & Minimum Order Quantity: 250 \\
\hline & $\begin{array}{l}\text { Order Cycle: } 750 \\
(3(D O C) \times 250(A D U))\end{array}$ & & $\begin{array}{l}\text { Order Cycle: } 900 \\
(3(D O C) \times 300(A D U))\end{array}$ \\
\hline Yellow Zone & $5000(20(D L T) \times 250(A D U))$ & Yellow Zone & $6900(23(\mathrm{DLT}) \times 300(\mathrm{ADU}))$ \\
\hline \multirow[t]{3}{*}{ Red Zone } & $1875(1250+625)$ & \multirow[t]{3}{*}{ Red Zone } & $2588(1725+863)$ \\
\hline & Base: $1250(5000 \times 0,25)$ & & Base: $1725(6900 \times 0,25)$ \\
\hline & Safety: $625(1250 \times 0,50)$ & & Safety: $863(1725 \times 0,50)$ \\
\hline
\end{tabular}

Fonte: Ptak e Smith (2016). 
Se o buffer estiver bem dimensionado o nível de inventário disponível deve estar na zona amarela. A Equação 11 apresenta a média de inventário disponível, pois, a zona amarela representa os pedidos em processo. Assim como a Figura 3.6 representa a média de distribuição alvo para o inventário disponível.

Média inventário disponível $=$ TOR $+1 / 2$ Green Zone

(Equação 11)

Figura 3.6 - Nível de inventário disponível alvo.

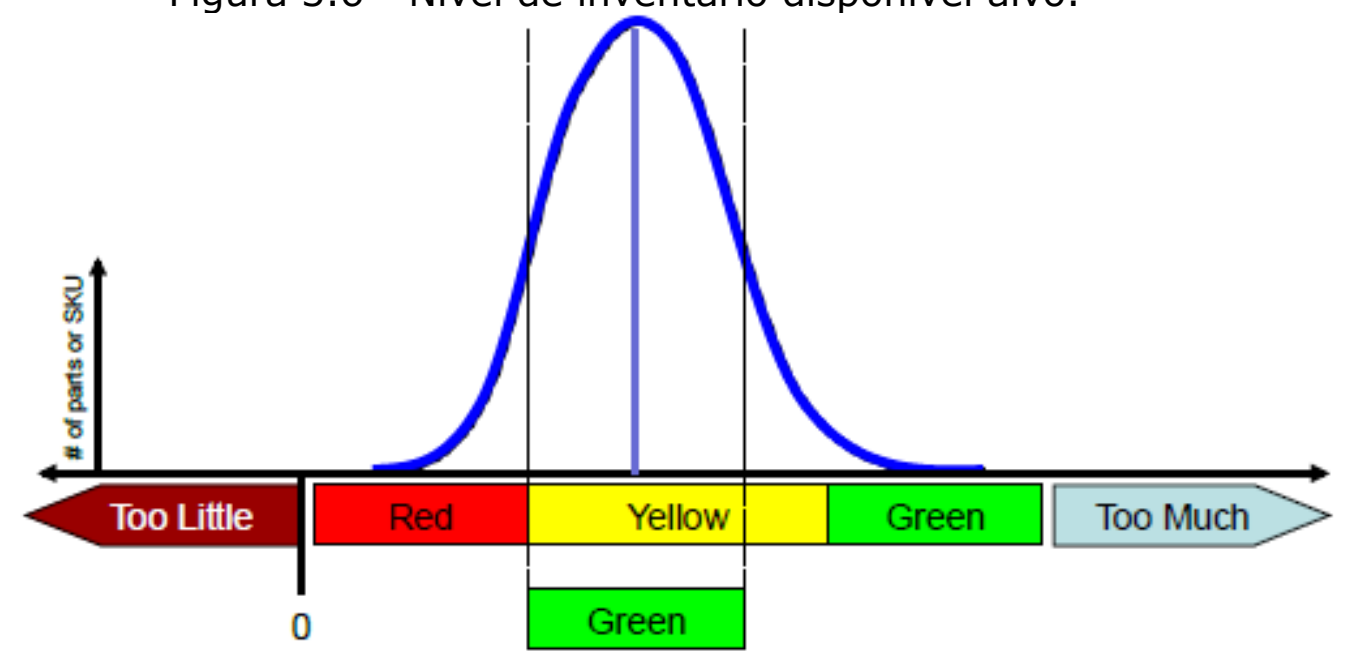

Fonte: Ptak e Smith (2016).

Seguindo esse entendimento tem-se o valor médio para o inventário disponível para o item FPA e FPC, do Quadro 3.2, como $1.875+1.250$ x 1/2, então 2.500 e $2588+1725$ x 1/2, resultando em 3.450 respectivamente.

Uma análise importante para justificar a utilização dos buffers é a do ponto de vista financeiro. Espera-se uma redução dos custos, com diminuição de itens em processo com o posicionamento de buffers. No texto original do método os autores utilizam a expressão "Working Capital", ou seja, é esperado uma redução na utilização de capital de giro, na forma de itens em processo, quando buffers são bem posicionados.

Para fazer essa análise utiliza-se a Figura 3.7 com as três listas de materiais para os itens FPA, FPB e FPC. Observando o subcomponente 201 para o item FPA observa-se um DLT de 20 dias $(1+5+4+10)$, se for posicionado um ponto de desacoplamento nesse componente 201 tem-se um DLT de 7 dias (passa a ser o caminho pelos componentes 303 e 203, com 
4+2+1). O Quadro 3.3 resume esses cálculos. O mesmo raciocínio pode ser aplicado para os itens FPB e FPC com o componente 201.

Quadro 3.3 - Comparação com o posicionamento de buffers.

\begin{tabular}{|c|c|c|c|}
\hline \multicolumn{4}{|l|}{ FPA } \\
\hline \multicolumn{4}{|c|}{ Componente 201 antes do desacoplamento } \\
\hline Uso diário médio & 250 & \multirow[t]{4}{*}{ Green Zone } & 1250 \\
\hline Perfil Buffer & $M, L(0,25), M(0,5)$ & & LT Factor: $1250(5000 \times 0,25)$ \\
\hline MOQ & 250 & & MQO: 250 \\
\hline $\begin{array}{l}\text { Ciclo de Pedidos } \\
\text { Desejado (DOC) }\end{array}$ & 3 dias & & $\begin{array}{l}\text { Order Cycle: } 750(3(D O C) \times 250 \\
(A D U))\end{array}$ \\
\hline \multirow{4}{*}{ DLI } & 20 dias & Yellow Zone & $5000(20(D L T) \times 250(A D U))$ \\
\hline & & \multirow[t]{3}{*}{ Red Zone } & $1875(1250+625)$ \\
\hline & & & Base: $1250(5000 \times 0,25)$ \\
\hline & & & Safety: $625(1250 \times 0,5)$ \\
\hline \multicolumn{4}{|c|}{ Componente 201 depois do desacoplamento } \\
\hline Uso diário médio & 250 & \multirow[t]{4}{*}{ Green Zone } & 750 \\
\hline Perfil Buffer & $M, M(0,40), L(0,25)$ & & LT Factor: $700(1750 \times 0,40)$ \\
\hline MOQ & 250 & & MQO: 250 \\
\hline $\begin{array}{l}\text { Ciclo de Pedidos } \\
\text { Desejado (DOC) }\end{array}$ & 3 dias & & $\begin{array}{l}\text { Order Cycle: } 750(3(\mathrm{DOC}) \times 250 \\
(\mathrm{ADU}))\end{array}$ \\
\hline \multirow[t]{4}{*}{ DLT } & 7 dias & Yellow Zone & $1750(7(D L T) \times 250(A D U))$ \\
\hline & & \multirow[t]{3}{*}{ Red Zone } & $875(700+175)$ \\
\hline & & & Base: $700(1750 \times 0,40)$ \\
\hline & & & Safety: $175(700 \times 0,25)$ \\
\hline
\end{tabular}

Fonte: Ptak e Smith (2016).

Figura 3.7 - Lista de materiais de FPA, FPB e FPC.
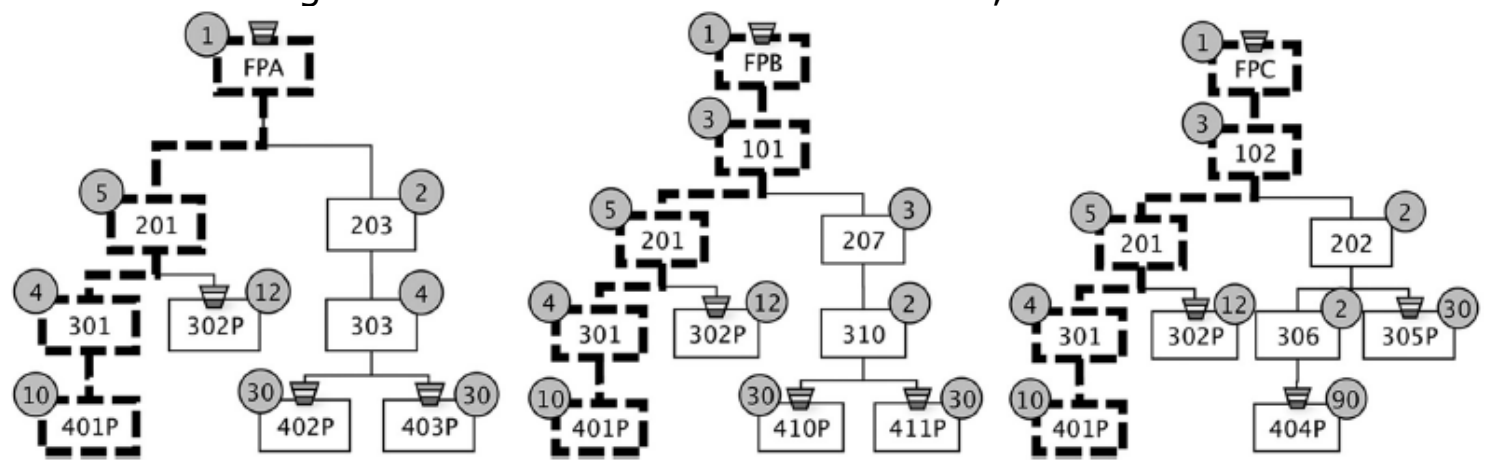

Fonte: Ptak e Smith (2016).

Com a compressão do lead time o perfil do buffer mudou, o "Lead Time Factor" passou de 25\% para 40\% e o "Variability Factor" mudou de 50\% para 
25\%. A partir desse momento essa compressão do lead time pode ser avaliada do ponto de vista financeiro.

Uma hipótese do DDMRP é: se essas alocações (alocações de mão-deobra) forem consideradas, o quadro se torna ainda mais inclinado em favor dos pontos de desacoplamento colocados no início da estrutura do produto; essas partes não recebem o "valor agregado" que os componentes de nível superior obtêm e, consequentemente, parecem "mais baratas" de se manter. No entanto, não há diferença real de uma perspectiva real de capital de giro (PTAK; SMITH, 2016; MICLO, 2016).

Em resumo, do ponto de vista de capital de giro, não há diferença se um buffer é posicionado no início do processo produtivo ou mais ao fim do processo com subcomponentes já manufaturados, de acordo com o ponto de vista dos autores do método (PTAK; SMITH, 2016).

Uma análise do ponto de vista financeiro é feita a seguir. O Quadro 3.4 apresenta os custos dos componentes comprados pela empresa para a produção de seus produtos.

Quadro 3.4 - Custo de subcomponentes comprados.

\begin{tabular}{ll|ll}
\hline Componente & Custo & Componente & Custo \\
\hline 302P & $\$ 100$ & $403 \mathrm{P}$ & $\$ 140$ \\
\hline 305P & $\$ 110$ & $404 \mathrm{P}$ & $\$ 125$ \\
\hline 401P & $\$ 110$ & $410 \mathrm{P}$ & $\$ 90$ \\
\hline 402P & $\$ 110$ & $411 \mathrm{P}$ & $\$ 200$ \\
\hline
\end{tabular}

Fonte: Ptak e Smith (2016).

A compressão do lead time reduziu a Média do inventário disponível de 2.500 para 1.250 , o que reduziu o inventário de um valor de $\$ 1.150 .000$ para $\$ 575.00$. O Quadro 3.5 resume essa análise. 
Quadro 3.5 - Análise de redução de inventário.

\begin{tabular}{|c|c|c|c|}
\hline \multicolumn{4}{|l|}{ FPA } \\
\hline \multicolumn{4}{|c|}{ Componente 201 antes do desacoplamento } \\
\hline Uso diário médio & 250 & \multirow[t]{4}{*}{ Green Zone } & 1250 \\
\hline Perfil Buffer & $M, L(0,25), M(0,5)$ & & LT Factor: $1250(5000 \times 0,25)$ \\
\hline MOQ & 250 & & MQO: 250 \\
\hline $\begin{array}{l}\text { Ciclo de Pedidos } \\
\text { Desejado (DOC) }\end{array}$ & 3 dias & & $\begin{array}{l}\text { Order Cycle: } 750(3(D O C) \times \\
250(A D U))\end{array}$ \\
\hline DLT & 20 dias & Yellow Zone & $5000(20(D L T) \times 250(A D U))$ \\
\hline Custo Direto Material & $\$ 460$ & \multirow[t]{3}{*}{ Red Zone } & $1875(1250+625)$ \\
\hline Média disponível alvo & $2500(1875+1 / 2 \times 1250)$ & & Base: $1250(5000 \times 0,25)$ \\
\hline Inventário médio & $\$ 1.150 .000$ & & Safety: $625(1250 \times 0,5)$ \\
\hline \multicolumn{4}{|c|}{ Componente 201 depois do desacoplamento } \\
\hline Uso diário médio & 250 & \multirow[t]{4}{*}{ Green Zone } & 750 \\
\hline Perfil Buffer & $M, M(0,40), L(0,25)$ & & LT Factor: $700(1750 \times 0,40)$ \\
\hline MOQ & 250 & & MQO: 250 \\
\hline $\begin{array}{l}\text { Ciclo de Pedidos } \\
\text { Desejado (DOC) }\end{array}$ & 3 dias & & $\begin{array}{l}\text { Order Cycle: } 750(3(D O C) \times \\
250(A D U))\end{array}$ \\
\hline DLT & 7 dias & Yellow Zone & $1750(7(D L T) \times 250(A D U))$ \\
\hline Custo Direto Material & $\$ 460$ & \multirow[t]{3}{*}{ Red Zone } & $875(700+175)$ \\
\hline Média disponível alvo & $1250(875+1 / 2 \times 750)$ & & Base: $700(1750 \times 0,40)$ \\
\hline Inventário médio & $\$ 575.000$ & & Safety: $175(700 \times 0,25)$ \\
\hline
\end{tabular}

Fonte: Adaptado de Ptak e Smith (2016).

Para finalizar essa análise deve-se avaliar também o impacto nos itens FPB e FPC quando colocado um buffer de desacoplamento no subcomponente 201 da lista de materiais desses produtos. Com a compressão do lead time nesses casos chega-se aos resultados resumidos no Quadro 3.6 a seguir.

Quadro 3.6 - Impacto do posicionamento de buffer.

\begin{tabular}{lrrrrr} 
& FPA & FPB & FPC & 201 & \multicolumn{1}{c}{ Inventário Total } \\
\hline Inicialmente & $\$ 1.150 .00$ & $\$ 575.250$ & $\$ 1.535 .473$ & $\$ 0$ & $\$ 3.260 .723$ \\
\hline Com Buffer & $\$ 575.00$ & $\$ 360.00$ & $\$ 747.600$ & $\$ 1.296 .960$ & $\$ 2.979 .560$ \\
\hline Redução & & & & $\$ 281.163$ \\
\hline
\end{tabular}

Fonte: Ptak e Smith (2016). 


\subsubsection{Ajuste Dinâmico}

O terceiro componente para implementação do DDMRP é o ajuste dinâmico dos estoques estabelecidos. À medida que a demanda dos clientes se torna mais volátil e o nível de incerteza aumenta mecanismos de ajustes devem ser implementados para manter o sistema apto a atingir os objetivos pretendidos. Os mecanismos pode ser os seguintes (MICLO, 2016):

a) À medida que a demanda muda, o ADU pode ser recalculado com uma média móvel (dependendo do DLT de referência) para lidar com as mudanças na tendência da demanda.

b) Em muitos setores existem períodos de sazonalidade, o DDMRP recomenda o uso de Fatores de Ajuste Planejados (PAF Planned Adjustment Factors) para lidar com esse fenômeno. Um fator desses é uma porcentagem aplicada ao ADU para mudar as dimensões da zona do buffer. Assim, um novo ADU é usado para dimensionar o buffer: ADU' = ADU x PAF.

c) O fator PAF é projetado para a geração futura de pedidos de fornecimento, pois o ADU será alterado.

d) O fator PAF também pode ser usado para estratégias de balanceamento de carga para "alterar artificialmente" o ADU por um período.

e) A ADU também pode ser ajustada para itens em expansão, retração ou transição. Esse raciocínio pode ser equivalente a aplicação do fator PAF para o ADU.

Essas alterações podem contribuir para mudanças no fator do lead time.

\subsubsection{Planejamento Demand Driven}

Até o momento o ambiente DDMRP foi modelado e projetado, o próximo passo é o monitoramento e execução. Os dois últimos componentes segundo a Figura 3.2 é o planejamento e a execução.

O objetivo do DDMRP é gerar ordens de produção na quantidade apropriada e no momento apropriado, para isso, introduz o conceito da Equação de Fluxo Líquido (NFE - "Net Flow Equation"). Essa equação leva em 
consideração o inventário disponível e as ordens de suprimento já geradas. Então essa demanda atual (do dia) deve ser removida da equação no que é chamado de "picos qualificados", do inglês "qualified spikes". Esses dois últimos conceitos são combinados em uma "demanda qualificada de pedidos de vendas". Esta é a principal diferença com uma posição de estoque "clássica". A equação, em inglês, é a seguinte (PTAK; SMITH, 2016; MICLO, 2016):

NFE $=$ On-hand + on order - qualified sales order demand (Equação 12)

Com uma tradução conceitual para o português, feita pelo autor, temos a seguinte equação:

NFE = "Inventário Disponível" + "Quantidade das ordens" - "Demanda qualificada de pedidos de venda" (Equação 13)

No planejamento Demand Driven enquanto a posição de fluxo líquido está na zona verde nenhuma ordem de suprimento é gerada. Assim que a posição de fluxo líquido entra na zona amarela uma ordem de suprimentos pode ser gerada. Esta quantidade da ordem deve ser a diferença entre a posição do fluxo líquido e o TOG. Esse conceito pode ser resumido pelo seguinte algoritmo lógico (PTAK; SMITH, 2016; MICLO, 2016):

\section{Enquanto NFE > TOG \\ Nenhuma ação}

Fim por enquanto

Se NFE $<=$ TOG então

Ordem de suprimento gerada $=$ TOG - NFE

Fim se

Comparado ao nível TOG, cada referência tem uma porcentagem aplicada que se ajusta ao nível de fluxo líquido em comparação ao seu TOG. Este formulário de planejamento ajuda a gerenciar visualmente o fluxo de pedidos de suprimentos, o Tabela 3.1 ilustra essa ideia (MICLO, 2016). 
Tabela 3.1 - Exemplo do planejamento DDMRP para prioridades. Data atual: 15 de julho

\begin{tabular}{|c|c|c|c|c|c|c|c|c|c|c|c|}
\hline Item & $\begin{array}{c}\text { Prioridade } \\
\text { de Planej. }\end{array}$ & Disponivel & $\begin{array}{c}\text { Em } \\
\text { Ordem }\end{array}$ & $\begin{array}{c}\text { Demanda } \\
\text { Qualificada }\end{array}$ & $\begin{array}{c}\text { Posição } \\
\text { de fluxo } \\
\text { líquido }\end{array}$ & $\begin{array}{c}\text { Ordem } \\
\text { Recomend. }\end{array}$ & $\begin{array}{c}\text { Data } \\
\text { Requerida }\end{array}$ & $\begin{array}{c}\text { Top } \\
\text { RED }\end{array}$ & $\begin{array}{c}\text { Top } \\
\text { YELLOW }\end{array}$ & $\begin{array}{c}\text { Top } \\
\text { GREEN }\end{array}$ & $\begin{array}{c}\text { Lead } \\
\text { Time }\end{array}$ \\
\hline $406 \mathrm{P}$ & $\begin{array}{c}\text { RED } \\
19,8 \%\end{array}$ & 401 & 506 & 263 & 644 & 2606 & $4 /$ AGO & 750 & 2750 & 3250 & 20 \\
\hline $403 \mathrm{P}$ & $\begin{array}{c}\text { YELLOW } \\
43,4 \%\end{array}$ & 1412 & 981 & 412 & 1981 & 2579 & $23 / \mathrm{JUL}$ & 1200 & 3600 & 4560 & 8 \\
\hline $402 \mathrm{P}$ & $\begin{array}{c}\text { YELLOW } \\
69,0 \%\end{array}$ & 601 & 753 & 112 & 1242 & 558 & $24 / \mathrm{JUL}$ & 540 & 1440 & 1800 & 9 \\
\hline $405 \mathrm{P}$ & $\begin{array}{c}\text { YELLOW } \\
74,0 \%\end{array}$ & 3400 & 4251 & 581 & 7070 & 2486 & $24 / \mathrm{JUL}$ & 1756 & 7606 & 9556 & 9 \\
\hline $401 \mathrm{P}$ & $\begin{array}{c}\text { YELLOW } \\
75,1 \%\end{array}$ & 2652 & 6233 & 712 & 8173 & 2715 & $25 / \mathrm{JUL}$ & 2438 & 8938 & 10888 & 10 \\
\hline $404 \mathrm{P}$ & $\begin{array}{c}\text { GREEN } \\
97,6 \%\end{array}$ & 1951 & 1560 & 291 & 3220 & 0 & - & 1050 & 2550 & 3300 & 6 \\
\hline
\end{tabular}

Fonte: Ptak e Smith (2016).

Quanto aos "picos qualificados", na teoria DDMRP, eles são levados em consideração no NFE se forem superiores à metade da zona vermelha (este limite pode ser ajustado pela empresa, mas sem raciocínio matemático) e em um horizonte definido. Por exemplo, pode não ser interessante qualificar um pico para uma demanda conhecida com dois meses de antecedência, com um DLT de referência de uma semana (MICLO, 2016).

Por fim, para a o planejamento das ordens, no DDMRP, a demanda é explodida apenas para o próximo buffer ou para uma terminação da BOM, conforme ilustrado na Figura 3.8. Esse raciocínio é chamado de "Explosão desacoplada do DDMRP - DDMRP Decoupled Explosion". Essa política de reordenamento é drasticamente diferente da explosão do MRP com demanda independente que é transmitida diretamente para cada peça no último nível da lista técnica (MICLO, 2016).

No entanto, entre os pontos de desacoplamento do DDMRP, um cálculo clássico do MRP é executado para gerar ordens. Um exemplo é detalhado com a Figura 3.19. Percebe-se que não existem estoques de segurança para os subcomponentes 210 e 310, portanto, os requisitos são iguais à ordem de fornecimento. Além disso, a explosão desacoplada para no próximo buffer estratégico do DDMRP. 
Figura 3.8 - Explosão desacoplado do DDMRP.

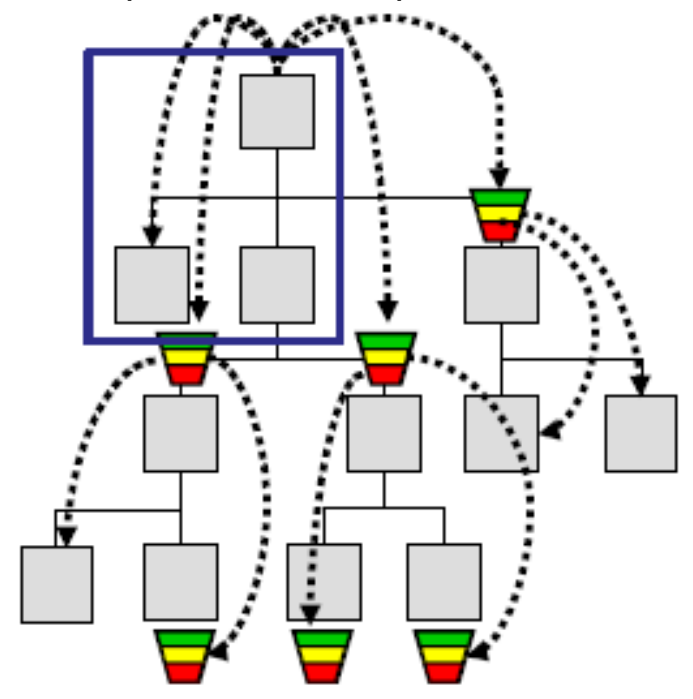

Fonte: Ptak e Smith (2016).

Figura 3.9 - Exemplo de geração de ordens.

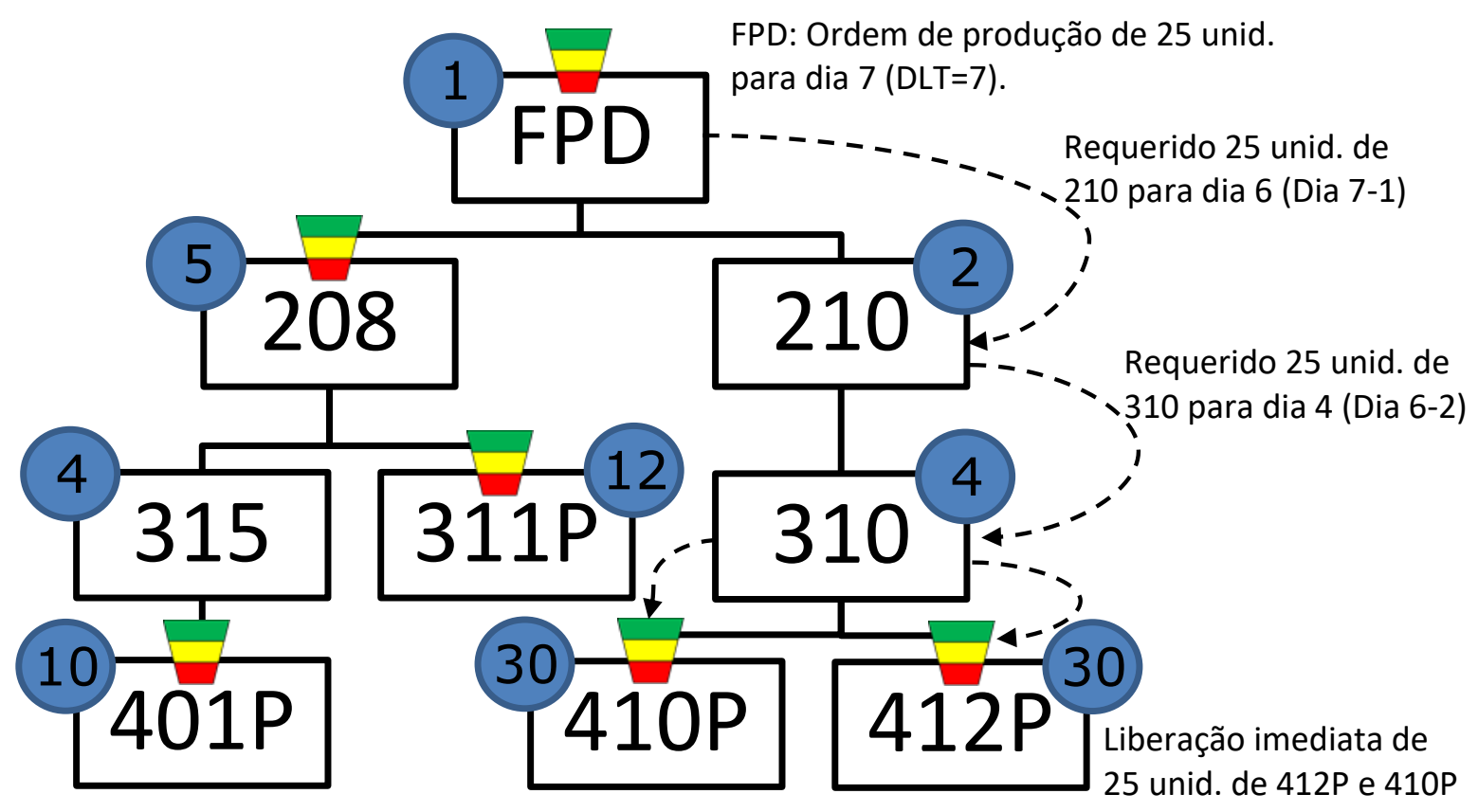

Fonte: Ptak e Smith (2016).

\subsubsection{Execução visual colaborativa}

Para ajudar na execução do método o DDMRP utiliza diferentes tipos de alertas, independentemente de existirem pontos dependentes ou independentes na lista de materiais. O objetivo desses alertas não é gerar 
ordens, mas criar prioridades de ordens já geradas e destacar possíveis emergências. Quanto aos alertas de ponto de dependência, eles lidam com alertas de sincronização (em termos de alertas de material ou de tempo) (MICLO, 2016). Os tipos de alertas são ilustrados na Figura 3.10.

Figura 3.10 - Tipos de Alertas do DDMRP.

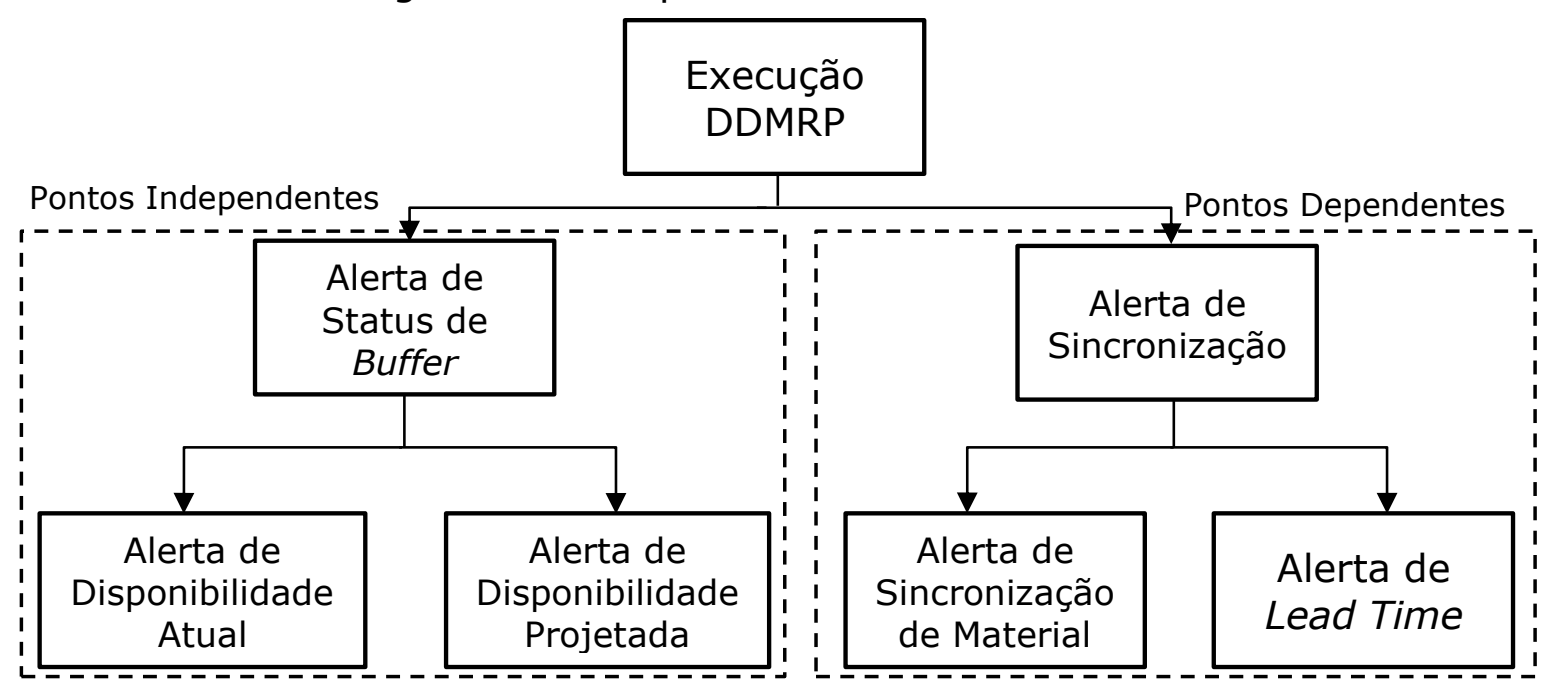

Fonte: Ptak e Smith (2016).

Como mostra a Figura 3.10 nos pontos independentes, os buffers do DDMRP, os alertas destacam a disponibilidade de inventário atual ou projetada. O Quadro 3.7 mostra como é mais fácil priorizar ordens de produção pelos alertas dos buffers ao contrário do sistema clássico de alerta por data de vencimento dos pedidos.

Quadro 3.7 - Exemplo de alerta de execução.

\begin{tabular}{lcll}
\hline Ordem & Data de Vencimento & Status do Buffer & Fornecedor \\
\hline PO 831145 & $05 / 12$ & RED $-\mathbf{1 2 , 3} \%$ & PNW FABRICAÇÃO \\
\hline PO 821158 & $05 / 12$ & YELLOW - 52,3\% & PNW FABRICAÇÃO \\
\hline PO 831162 & $05 / 12$ & YELLOW - 56,1\% & PNW FABRICAÇÃO
\end{tabular}

Fonte: Ptak e Smith (2016).

Pelo Quadro 3.7 percebe-se que a prioridade é a ordem PO 831145 , mas em um painel clássico apenas com a data de vencimento do pedido ficaria difícil perceber a prioridade. 


\subsection{REVISÃO DA LITERATURA SOBRE DDMRP}

Como destacado no capítulo 1 do trabalho, o tema DDMRP ainda é muito recente, logo, foi pouco explorado e possui poucos trabalhos acadêmico-científicos publicados. Pesquisas nas bases de dados Web of Science, Scopus e Engineering Village, que são as principais fontes de busca para fins científicos (BUCHINGER; CAVALCANTI; HOUNSELL, 2014), encontram poucos resultados.

Essa seção do trabalho apresenta os resultados das buscas, descrevendo esses estudos e os resultados alcançados pelos mesmos. Para as buscas foram utilizadas as seguintes palavras chaves: "DDMRP", "demand driven MRP", "demand driven material requirements planning", que fazem referência direta ao tema central da pesquisa. Pode-se agrupá-las por operadores lógicos para formação da seguinte string de busca: ("DDMRP" OR "demand driven MRP" OR "demand driven material requirements planning"). Foram considerados inicialmente apenas resultados em língua inglesa por questões de acesso e disponibilidade.

Foram encontrados inicialmente 6 artigos revisados por pares, de journals e revistas internacionais e 4 artigos de congressos e conferências internacionais nas bases de dados Web of Science, Scopus e Engineering Village. Após isso, pelo método "snow ball" (bola de neve, em uma tradução direta e livre feita pelo próprio autor), que é uma técnica para encontrar autores citados por outros autores (COHEN; ARIELI, 2011), foram localizados outros 2 artigos de congressos e 2 trabalhos acadêmicos de mestrado e doutorado. Posteriormente, durante a survey, foi adicionado mais um artigo revisado por pares, o artigo foi uma recomendação de um dos especialistas, ele não havia sido retornado na pesquisa anteriormente por estar publicado em francês. Dessa forma, foram localizados 15 estudos no total.

O Quadro 3.8 apresenta os estudos encontrados, com os autores, 0 método utilizado e uma breve descrição do trabalho e resultados. 
Quadro 3.8 - Estudos localizados sobre o método DDMRP.

Descrição

\section{Resultados e conclusões}

\begin{tabular}{ll}
\hline Autores & Método \\
\hline & \\
& \\
& \\
Orue, Lizarralde & Revisão \\
e Kortabarria & sistemática da \\
$(2020)$ & literatura
\end{tabular}

Os autores destacam o aumento do interesse pelo método DDMRP em meio a mudanças no mercado, com maior variedade de produtos e redução de seus ciclos de vida. Dessa forma, os pesquisadores propõem uma revisão da literatura para identificar se outros autores investigaram a padronização do processo de implementação do DDMRP.

Estudo por meio de simulação utilizando como cenário o "Kanban game", um jogo desenvolvido para ensino do método kanban. O jogo é baseado em um chão de fábrica com estações de trabalho que produzem redutores de
Miclo et al.
Simulação de evento discreto velocidade. São estabelecidos os parâmetros e feita a simulação para comparar o desempenho do DDMRP, MRP II e kanban em dois cenários, baixa ou alta variabilidade da demanda. Foram feitas 240 simulações e na média o DDMRP apresentou melhor resultado que os outros dois Foram identificados na literatura trabalhos que procuraram demonstrar a necessidade de os sistemas de gestão atenderem os novos requisitos, outros que comparam os benefícios do DDMRP frente ao MRP e pesquisas que exploraram métodos matemáticos para posicionamento e dimensionamento dos buffers. Os autores concluem, porém, que há uma lacuna de estudos sobre o processo de implementação.

Para baixa variabilidade de demanda o indicador OTD é estatisticamente igual para o DDMRP e kanban, porém superiores ao MRP II, já o indicador WIP do DDMRP apresenta o melhor resultado, com menor nível de estoque. No cenário com alta variabilidade de demanda o OTD do DDMRP é o melhor, com pouca diferença para o cenário de baixa variabilidade, com relação a WIP o kanban e o DDMRP apresentam resultados similares, superiores ao MRP II.

métodos. 
Quadro 3.8 - Estudos localizados sobre o método DDMRP.

\begin{tabular}{|c|c|c|c|}
\hline Autores & Método & Descrição & Resultados e conclusões \\
\hline $\begin{array}{l}\text { Velasco Acosta, } \\
\text { Mascle e } \\
\text { Baptiste (2019) }\end{array}$ & $\begin{array}{l}\text { Simulação de } \\
\text { evento discreto }\end{array}$ & $\begin{array}{l}\text { No estudo os autores simularam uma fábrica } \\
\text { com um ambiente complexo, em termos de } \\
\text { níveis de lista de materiais (4 níveis) e } \\
\text { posicionamento dos buffers. Para a execução } \\
\text { do DDMRP foi usado o software ARENA, e foram } \\
\text { analisados os indicadores estoque médio } \\
\text { disponível e lead time, classificados em nível de } \\
\text { estoque e satisfação do consumidor. }\end{array}$ & $\begin{array}{l}\text { Os pesquisadores concluíram que avaliando o } \\
\text { DDMRP através desses indicadores é possível } \\
\text { afirmar que o método é aplicável a ambientes } \\
\text { complexos, tendo reduzido os estoques e } \\
\text { aumentado a satisfação dos consumidores. }\end{array}$ \\
\hline $\begin{array}{l}\text { Pekarcíková et } \\
\text { al. (2019) }\end{array}$ & $\begin{array}{l}\text { Revisão da } \\
\text { literatura e } \\
\text { estudo de caso } \\
\text { simulado }\end{array}$ & $\begin{array}{l}\text { O objetivo do estudo é promover um aumento } \\
\text { do conhecimento sobre o DDMRP. Os } \\
\text { pesquisadores identificam questões que } \\
\text { dificultam os métodos PCP atuais e enxergam } \\
\text { potencial no DDMRP em apresentar melhores } \\
\text { resultados nesse cenário. Para avaliar essa } \\
\text { possibilidade realizam um estudo de caso } \\
\text { simulado, em que um caso real é simplificado } \\
\text { para demonstrar o passo a passo e } \\
\text { dimensionamento dos elementos da } \\
\text { implementação do DDMRP e a execução do } \\
\text { método. }\end{array}$ & $\begin{array}{l}\text { Os autores concluem que o DDMRP evita o efeito } \\
\text { chicote, é aplicável a todo portifólio da } \\
\text { companhia, mas pode ser aplicado apenas a uma } \\
\text { parte dos produtos, o posicionamento de buffers } \\
\text { do DDMRP não é adequado para matérias primas } \\
\text { de longo lead time de entrega e quando os } \\
\text { fornecedores são geridos por contratos em que a } \\
\text { volatilidade do preço força a empresa a comprar } \\
\text { mais que o necessário. }\end{array}$ \\
\hline
\end{tabular}


Quadro 3.8 - Estudos localizados sobre o método DDMRP.

\begin{tabular}{|c|c|c|c|}
\hline Autores & Método & Descrição & Resultados e conclusões \\
\hline $\begin{array}{l}\text { Bahu, Bironneau } \\
\text { e Hovelaque } \\
\text { (2019) }\end{array}$ & $\begin{array}{l}\text { Estudo } \\
\text { empírico com } \\
\text { casos reais }\end{array}$ & $\begin{array}{l}\text { Os autores começam o artigo destacando o } \\
\text { contexto atual das cadeias de suprimentos que } \\
\text { se encontram em um ambiente de mudança, } \\
\text { com volatilidade de demanda, complexidade na } \\
\text { tomada de decisão, dificuldade de previsão, } \\
\text { entre outros fatores. Assim, apresentam o } \\
\text { DDMRP como uma possibilidade para superar } \\
\text { esses desafios. O estudo empírico é feito com } \\
26 \text { casos disponibilizados pelo DDI e mais } 4 \\
\text { casos observados pelos autores. Dessa forma } \\
\text { eles buscam entender a atratividade do DDMRP } \\
\text { para as empresas. }\end{array}$ & $\begin{array}{l}\text { Os autores afirmam que as empresas pioneiras na } \\
\text { adoção do DDMRP usavam anteriormente a lógica } \\
\text { da teoria das restrições, o tambor-pulmão-corda. } \\
\text { Dessa forma, os relatos positivos sobre melhoria } \\
\text { na taxa de atendimento, redução de estoques e } \\
\text { gestão simplificada atraíram mais empresas a } \\
\text { implementarem o método. Outro fator importante } \\
\text { é a possibilidade de integração com software de } \\
\text { ERP, centralizando a gestão da cadeia logística. } \\
\text { Os autores concluem que a insatisfação das } \\
\text { empresas com os softwares usados } \\
\text { anteriormente em atingir metas de nível de } \\
\text { serviço e nível de estoque as levaram a procurar } \\
\text { alternativas, como o DDMRP. }\end{array}$ \\
\hline
\end{tabular}


Quadro 3.8 - Estudos localizados sobre o método DDMRP.

\begin{tabular}{|c|c|c|c|}
\hline Autores & Método & Descrição & Resultados e conclusões \\
\hline $\begin{array}{l}\text { Lee e Rim } \\
\text { (2019) }\end{array}$ & Simulação & $\begin{array}{l}\text { Os autores identificam uma vulnerabilidade na } \\
\text { modelagem dos buffers do DDMRP e propõem } \\
\text { um método matemático para calcular o fator de } \\
\text { lead time (Quadro } 3.1 \text { ). Os pesquisadores } \\
\text { afirmam que essa subjetividade na } \\
\text { determinação desse fator põe em risco a } \\
\text { consistência do método e que um modelo } \\
\text { matemático para ele, de acordo com } \\
\text { parâmetros da produção, traz mais } \\
\text { consistência e melhores resultados ao DDMRP. }\end{array}$ & $\begin{array}{l}\text { Por meio da simulação os autores compararam o } \\
\text { desempenho dessa proposição com o método do } \\
\text { DDMRP e com um método de estoque de } \\
\text { segurança padrão. O resultado apontou que o } \\
\text { modelo proposto pelos autores apresentou } \\
\text { melhor resultado em todos os casos quando } \\
\text { comparado ao método do DDMRP e em quase } \\
\text { todos em comparação ao método tradicional, } \\
\text { reduzindo o estoque médio e com mesma } \\
\text { consistência de evitar a falta de estoque. }\end{array}$ \\
\hline
\end{tabular}


Quadro 3.8 - Estudos localizados sobre o método DDMRP.

\begin{tabular}{|c|c|c|c|}
\hline Autores & Método & Descrição & Resultados e conclusões \\
\hline $\begin{array}{l}\text { Ducrot e Ahmed } \\
\text { (2019) }\end{array}$ & $\begin{array}{l}\text { Entrevistas e } \\
\text { survey }\end{array}$ & $\begin{array}{l}\text { O estudo foi realizado em duas etapas, na } \\
\text { primeira foram realizadas entrevistas } \\
\text { semiestruturadas com algumas empresas que } \\
\text { implementaram o DDMRP e na segunda etapa } \\
\text { foi feita uma survey. }\end{array}$ & $\begin{array}{l}\text { Os autores relataram que as empresas tiveram } \\
\text { uma redução média de } 20 \% \text { no nível de inventário } \\
\text { após a implementação do DDMRP. As companhias } \\
\text { com Fast-Moving Products tiveram uma ligeira } \\
\text { queda no giro de estoque com o DDMRP e as com } \\
\text { Slow-Moving Products um aumento na velocidade } \\
\text { de giro de estoque. O gestores avaliaram que o } \\
\text { DDMRP proporcionou um planejamento e } \\
\text { programação de produção mais estável, nível de } \\
\text { prioridade mais claro, mais controle sobre a } \\
\text { operação e forneceu mais informações relevantes. } \\
\text { O DDMRP apresentou mudanças e resultados mais } \\
\text { sigficativos quando comparados com empresas que } \\
\text { o implantaram com MRP como sistema prévio, } \\
\text { quando as empresas já pussiam um sistema APS o } \\
\text { DDMRP melhorou de forma geral, mas os } \\
\text { resultados não foram tão altos quando comparados } \\
\text { ao MRP. }\end{array}$ \\
\hline
\end{tabular}


Quadro 3.8 - Estudos localizados sobre o método DDMRP.

\begin{tabular}{|c|c|c|c|}
\hline Autores & Método & Descrição & Resultados e conclusões \\
\hline $\begin{array}{l}\text { Kortabarria et } \\
\text { al. (2018) }\end{array}$ & $\begin{array}{l}\text { Estudo de caso } \\
\text { qualitativo }\end{array}$ & $\begin{array}{l}\text { No artigo os pesquisadores descrevem o } \\
\text { procedimento de planejamento da empresa } \\
\text { antes na implementação do DDMRP e como } \\
\text { ficou após a implementação. Os autores } \\
\text { descrevem que a empresa tinha dificuldades } \\
\text { com longos lead times de fornecedores, } \\
\text { exigência de curto lead time de clientes e difícil } \\
\text { previsão de vendas. Antes da implementação o } \\
\text { gestor responsável realizava o planejamento } \\
\text { de materiais mensalmente e ocorriam } \\
\text { dificuldades por falta de gestão visual levando } \\
\text { a falta de estoques e atrasos nas entregas. }\end{array}$ & $\begin{array}{l}\text { Após a implantação do DDMRP houve ganho de } \\
\text { agilidade na execução e planejamento de } \\
\text { materiais que passou a ser semanal. Como } \\
\text { resultado houve decréscimo no nível de estoque } \\
\text { geral em cerca de } 56 \% \text {, aumento do uso médio } \\
\text { diário de materiais em } 8,7 \% \text { e considerável } \\
\text { aumento do giro de estoque. }\end{array}$ \\
\hline $\begin{array}{l}\text { Shofa, Moeis e } \\
\text { Restiana (2018) }\end{array}$ & Simulação & $\begin{array}{l}\text { Simulação com base em um caso real para } \\
\text { comparar o nível de inventário médio do MRP e } \\
\text { do DDMRP. A investigação é para uma peça } \\
\text { comprada com longo lead time de entrega, } 45 \\
\text { dias e a demanda prevista para um ano. Foi } \\
\text { realizada uma simulação de operação de } 180 \\
\text { dias. }\end{array}$ & $\begin{array}{l}\text { O DDMRP apresentou melhor resultado no nível } \\
\text { de estoque médio, } 95.284 \text { peças contra } 106.852 \\
\text { do MRP, redução de } 11 \% \text {. Além disso, o MRP } \\
\text { apresentou instabilidade no estoque para o fim do } \\
\text { período, o que o deixa suscetível a quebras de } \\
\text { estoque. Os pesquisadores concluem que o } \\
\text { DDMRP foi mais efetivo para o planejamento da } \\
\text { produção do que o MRP. }\end{array}$ \\
\hline
\end{tabular}


Quadro 3.8 - Estudos localizados sobre o método DDMRP.

\begin{tabular}{|c|c|c|c|}
\hline Autores & Método & Descrição & Resultados e conclusões \\
\hline $\begin{array}{l}\text { Shofa e } \\
\text { Widyarto (2017) }\end{array}$ & Simulação & $\begin{array}{l}\text { Foi usado como base uma indústria do setor } \\
\text { automobilístico em que foram simuladas quatro } \\
\text { semanas. Foi utilizado um produto como base } \\
\text { que possui dois componentes, os dados da } \\
\text { previsão foram fornecidos pela empresa e } \\
\text { variações foram aplicadas para fazer um } \\
\text { ambiente estocástico. Foram analisados os } \\
\text { indicadores de lead time e nível de inventário. }\end{array}$ & $\begin{array}{l}\text { O DDMRP apresentou melhores resultados em } \\
\text { todas as ocasiões da simulação, diminuindo o } \\
\text { lead time de } 52 \text { dias para } 3 \text { dias e nenhuma } \\
\text { situação de quebra de estoque aconteceu. Já no } \\
\text { MRP para o produto final houve quebra de } \\
\text { estoque uma vez e para um dos componentes } \\
\text { duas vezes. Quanto a nível de estoque o DDMRP } \\
\text { apresenta melhor controle do inventário, com ele } \\
\text { controlado na zona amarela dos buffers em mais } \\
\text { de } 70 \% \text { do tempo, já o MRP apresenta maior } \\
\text { descontrole do inventário, com os componentes } \\
\text { em mais de } 90 \% \text { do tempo na zona vermelha e o } \\
\text { produto final com excesso de inventário em } 41 \% \\
\text { do tempo. }\end{array}$ \\
\hline
\end{tabular}


Quadro 3.8 - Estudos localizados sobre o método DDMRP.

\begin{tabular}{|c|c|c|c|}
\hline Autores & Método & Descrição & Resultados e conclusões \\
\hline Miclo (2016) & $\begin{array}{l}\text { Simulação e } \\
\text { estudo de caso }\end{array}$ & $\begin{array}{l}\text { O trabalho faz uma apresentação e análise } \\
\text { crítica do DDMRP, o compara com outros dois } \\
\text { métodos de PCP, kanban e MRP; realiza uma } \\
\text { simulação com base no "kanban game" e um } \\
\text { estudo de caso baseado em uma empresa do } \\
\text { setor aeronáutico para comparar o } \\
\text { desempenho do DDMRP com o MRP tradicional } \\
\text { anteriormente usado na empresa por um } \\
\text { módulo do sistema ERP. }\end{array}$ & $\begin{array}{l}\text { Para a simulação do "kanban game" o DDMRP e o } \\
\text { kanban apresentaram melhores resultados do que } \\
\text { o MRP para os indicadores OTD e WC no cenário de } \\
\text { alta variabilidade de demanda. Quando se adiciona } \\
\text { a esse cenário picos de sazonalidade o DDMRP } \\
\text { supera os resultados alcançados pelo kanban. Além } \\
\text { disso, o DDMRP possui uma capacidade de lidar } \\
\text { com grande número de itens maior que o kanban. } \\
\text { Para o estudo de caso o autor identificou alguns } \\
\text { pontos importantes: o DDMRP e o MRP podem } \\
\text { coexistir; anteriormente a empresa usava o } \\
\text { sistema de reposta à demanda MTO, com o DDMRP } \\
\text { pôde-se utilizar também o MTS com os buffers; } \\
\text { houve aumento da flexibilidade do sistema com o } \\
\text { DDMRP; o calculo do NFE pode se adaptar ao } \\
\text { ambiente e no caso estudado o cálculo semanal foi } \\
\text { suficiente. }\end{array}$ \\
\hline
\end{tabular}


Quadro 3.8 - Estudos localizados sobre o método DDMRP.

\begin{tabular}{|c|c|c|c|}
\hline Autores & Método & Descrição & Resultados e conclusões \\
\hline $\begin{array}{l}\text { Miclo et al. } \\
(2016 a)\end{array}$ & $\begin{array}{l}\text { Simulação de } \\
\text { evento discreto }\end{array}$ & $\begin{array}{l}\text { O estudo se dá por simulação de evento } \\
\text { discreto com base no "kanban game". Foram } \\
\text { simulados sete cenários, o primeiro base, de } \\
\text { acordo com o jogo didático e outros seis com } \\
\text { adição de fontes de variabilidade em cima do } \\
\text { cenário original, essas fontes foram desde } \\
\text { variabilidade interna (lead time) a externa } \\
\text { (demanda, sazonalidade e picos de demanda). } \\
\text { Foram avaliados os indicadores OTD, WC e de } \\
\text { forma geral a instabilidade do sistema, } \\
\text { comparando o DDMRP com o MRP II. }\end{array}$ & $\begin{array}{l}\text { Para todos os cenários o DDMRP atendeu o } \\
\text { percentual mínimo de } 99,3 \% \text { de OTD, com } \\
\text { exceção de quando picos de demanda ocorriam } \\
\text { em conjunto com sazonalidade, pois os picos } \\
\text { eram exatamente no momento da alta na } \\
\text { sazonalidade. Isso pode ser evitado com a } \\
\text { antecipação dos picos, comprovado pelo cenário } \\
\text { em que ocorrem picos, sazonalidade e visibilidade } \\
\text { da demanda. Além disso, o DDMRP sempre } \\
\text { apresentou menor WC, com estoques e WIP em } \\
\text { média } 10 \% \text { menores que o MRP II e menor } \\
\text { instabilidade do sistema. }\end{array}$ \\
\hline
\end{tabular}


Quadro 3.8 - Estudos localizados sobre o método DDMRP.

\begin{tabular}{|c|c|c|c|}
\hline Autores & Método & Descrição & Resultados e conclusões \\
\hline $\begin{array}{l}\text { Miclo et al. } \\
(2016 b)\end{array}$ & $\begin{array}{l}\text { Simulação de } \\
\text { evento discreto }\end{array}$ & $\begin{array}{l}\text { O artigo usa o método de simulação de evento } \\
\text { discreto como base para parametrização do } \\
\text { sistema no "kanban game". Três situações } \\
\text { foram simuladas para serem analisadas, a } \\
\text { primeira, padrão com o MRP II, a segunda com } \\
\text { os mesmos parâmetros para o DDMRP e uma } \\
\text { terceira com um fator de ajuste no lead time } \\
\text { para analisar o DDMRP, em que aumentou-se a } \\
\text { zona verde do buffer, tornando o tamanho do } \\
\text { lote maior, logo, houve menos tempo de } \\
\text { setups. }\end{array}$ & $\begin{array}{l}\text { O MRP II apresentou melhor OTD, 93\%, contra } \\
91 \% \text { para o DDMRP nas mesmas condições e } 90 \% \\
\text { para o DDMRP com o fator de ajuste do lead time. } \\
\text { Porém, o MRP II apresenta maior WC, na média } \\
28 \% \text { a mais que o DDMRP e com o fator de ajuste } \\
\text { o MRP II apresenta WC em média } 12 \% \text { maior que } \\
\text { o DDMRP. De maneira geral o MRP II apresenta } \\
\text { melhor resultado para o OEE nos processos, } \\
\text { entretanto as hipóteses da simulação favorecem } \\
\text { o MRP II, pois a demanda é estável e previsível, } \\
\text { o setup é longo nos gargalos o que dificulta para } \\
\text { processos puxados e diminui a flexibilidade. }\end{array}$ \\
\hline
\end{tabular}


Quadro 3.8 - Estudos localizados sobre o método DDMRP.

\begin{tabular}{|c|c|c|c|}
\hline Autores & Método & Descrição & Resultados e conclusões \\
\hline $\begin{array}{l}\text { Ihme e Stratton } \\
\text { (2015) }\end{array}$ & $\begin{array}{l}\text { Estudo de caso } \\
\text { e simulação }\end{array}$ & $\begin{array}{l}\text { A pesquisa se iniciou por um estudo de caso em } \\
\text { uma empresa produtora de tintas, foi levantado } \\
\text { por meio de uma survey interna problemas } \\
\text { associados ao planejamento e controle da } \\
\text { produção que causavam baixo desempenho na } \\
\text { produção. Após isso, foi feita uma simulação de } \\
\text { como seria a produção de um período passado } \\
\text { com o DDMRP. Para isso, foram usados dados } \\
\text { do ano de } 2013 \text { de vendas; para minimizar a } \\
\text { limitação do estudo foi feito com que a } \\
\text { visibilidade da previsão de vendas fosse de } \\
\text { duas semanas, como seria a previsão na } \\
\text { realidade. }\end{array}$ & $\begin{array}{l}\text { Como resultado para a survey foram identificados } \\
\text { seis fatores principais: escassez frequente de } \\
\text { produtos acabados, nível excessivo na expedição, } \\
\text { escassez frequente de matéria prima, plano de } \\
\text { produção com vida muito limitada, lead times de } \\
\text { produção altos e caos geral. A simulação paras os } \\
28 \text { produtos analisados resultou que o DDMRP } \\
\text { mostrou as seguintes melhorias: redução de } 43 \% \\
\text { de alertas de nível de inventário alto, redução em } \\
45 \% \text { de alertas de falta de inventário e redução } \\
\text { de } 95 \% \text { de faltas de estoque. }\end{array}$ \\
\hline
\end{tabular}


Quadro 3.8 - Estudos localizados sobre o método DDMRP.

\begin{tabular}{|c|c|c|c|}
\hline Autores & Método & Descrição & Resultados e conclusões \\
\hline $\begin{array}{l}\text { McCullen e Eagle } \\
\text { (2015) }\end{array}$ & $\begin{array}{l}\text { Survey e } \\
\text { estudo de caso }\end{array}$ & $\begin{array}{l}\text { A pesquisa foi inicializada por uma survey } \\
\text { qualitativa com consultores para explorar } \\
\text { questões de implantação do DDMRP, como por } \\
\text { exemplo: quantas empresas implantaram o } \\
\text { método, setores de mercado dessas empresas, } \\
\text { características dessas companhias, quais } \\
\text { problemas motivaram a adoção do método } \\
\text { DDMRP. Após essa pesquisa geral foi realizado } \\
\text { um estudo de caso para relatar os resultados } \\
\text { de uma empresa que implantou o método. }\end{array}$ & $\begin{array}{l}\text { Os pesquisadores relataram que identificaram } 61 \\
\text { empresas que implantaram o DDMRP. Através de } \\
\text { relatos dos consultores pela survey afirmaram } \\
\text { que empresas conseguiram diminuir atrasos, lead } \\
\text { time e inventário, aumentando a responsividade. } \\
\text { O DDRMP proporcionou buffers com custo } \\
\text { eficiente e sem excesso de inventário. Muitas das } \\
\text { companhias que implantaram o método o fizeram } \\
\text { pois estavam desapontadas com os resultados do } \\
\text { pacote de planejamento e otimização avançado } \\
\text { do MRP/ SAP, e que para o mercado de empresas } \\
\text { médias esse tipo de solução é mais acessível. } \\
\text { Entre os problemas que motivaram a implantação } \\
\text { foram identificados problemas de fluxo de caixa, } \\
\text { nível de serviço ruim, alto nível de inventário, } \\
\text { receitas em declínio e proposta de melhoria } \\
\text { contínua de melhores práticas. }\end{array}$ \\
\hline
\end{tabular}

Fonte: Elaborado pelo autor. 


\subsection{CONCLUSÃO DO CAPÍTULO}

Dessa forma, ao longo do capítulo foi apresentada a metodologia do DDMRP e uma revisão dos trabalhos científicos publicados sobre o tema. Pode-se, então, concluir esse capítulo com os fatores de implementação específicos da teoria DDMRP selecionados para serem constructos do questionário para o estudo pelo método Fuzzy Delphi, esses fatores foram em sua maioria propostos pelo autor com base na literatura do capítulo, uma vez que o tema ainda não foi explorado por outros autores.

A seguir são apresentados os fatores selecionados com as referências e um breve comentário justificando a seleção.

a) motivações para implementação:

$\checkmark$ Redução / controle de inventário: motivação proposta com base na teoria do DDMRP e em estudos da revisão bibliográfica do DDMRP que descrevem melhorias como redução e controle de estoques. Além disso, os trabalhos de McCullen e Eagle (2015) e Bahu, Bironneau e Hovelaque (2019) relata que as empresas buscaram o DDMRP para melhorar o desempenho das operações nesse quesito;

$\checkmark$ Redução de custo operacional: proposto com base na teoria do DDMRP e relato de McCullen e Eagle (2015) que indica melhor eficiência de custos no DDMRP;

$\checkmark$ Reduzir lead time da manufatura: o DDMRP se propõe a comprimir o lead time de manufatura com posicionamento de buffers, além disso, trabalhos consultados (seção 3.3) concluíram redução significativa do lead time com o DDMRP, além dos pontos colocados no Capítulo 2;

$\checkmark$ Reduzir / eliminar taxa de stock-out (quebras de estoques): motivação proposta pois o DDMRP visa proteger o fluxo, impedindo a falta de estoques e com base em conclusões de trabalhos que descrevem que 0 método reduziu significativamente taxas de stock-out; 
$\checkmark$ Reduzir a instabilidade do sistema MRP: proposto pelo autor com base em Miclo (2016) e Shofa, Moeis e Restiana (2018) que em estudos de simulação concluíram que o DDMRP reduz a instabilidade quando comparado ao MRP;

$\checkmark$ Reduzir prazo de entrega: proposto pelo autor com base na teoria do DDMRP que busca comprimir o lead time e proporcionar maior agilidade, o que pode ser entendido em menores prazos de entrega;

$\checkmark$ Reduzir uso de capital de giro: proposto pelo autor com base na teoria do DDMRP que segundo Ptak e Smith (2016) reduz o uso de capital de giro e com base em Miclo et al. (2016a; 2016b) que mostram resultados, por meio de simulação, em linha com a teoria;

$\checkmark$ Aumentar agilidade / responsividade: proposto pelo autor com base nos resultados de McCullen e Eagle (2015) e Kortabarria et al. (2018) que apontam ganho de agilidade e responsividade do DDMRP quando comparado ao MRP, além dos pontos do Capítulo 2;

$\checkmark$ Aumentar flexibilidade: proposto pelo autor com base nos resultados de Miclo (2016) que indicam ganho de flexibilidade na adoção do DDMRP perante o MRP;

$\checkmark$ Aumentar a eficiência: proposto com base na teoria do DDMRP, que sugere o método com melhor eficiência de custo e uso de recursos e com base nos trabalhos de McCullen e Eagle (2015) e Bahu, Bironneau e Hovelaque (2019) que destacam a procura pelo DDMRP por insatisfação com sistemas prévios pouco eficientes;

$\checkmark$ Orientação à demanda: proposto com base na teoria do DDMRP, em que o método se guia pela demanda e não por previsões, além dos pontos do Capítulo 2;

$\checkmark$ Apoiar iniciativas Lean: proposto pelo autor para investigar a hipótese de interesse pelo método por ele utilizar princípios do Lean na sua teoria;

$\checkmark$ Adaptabilidade à ambientes de incerteza (demanda): proposto pelo autor com base em resultados obtidos por simulação de 
Miclo (2016) e Miclo et al. (2019) que indicam melhores resultados do DDMRP em ambientes de variabilidade da demanda em comparação do MRP;

$\checkmark$ Ajuste dinâmico de inventário (para a sazonalidade): proposto pelo autor com base na teoria do DDMRP, o método possui ajuste dinâmico de acordo com ciclo de vida dos produtos ou sazonalidades;

$\checkmark$ Aplicar melhores práticas de mercado: proposto com base em McCullen e Eagle (2015) em os autores descrevem que empresas buscaram o DDMRP após relatos de bons resultados de outros usuários, além dos motivos do Capítulo 2;

$\checkmark$ Melhorar priorização e sequenciamento de ordens: proposto pelo autor com base em Ducrot e Ahmed (2019), que afirmaram que o DDMRP proporciona melhor programação de produção e nível de prioridade mais claro;

$\checkmark$ Melhorar pontualidade de entrega: motivação proposta pelo autor com base nos trabalhos de Miclo et al. (2019) e Miclo (2016) que indicam melhor pontualidade de entrega para o DDMRP quando comparado ao MRP, especialmente em ambientes de variabilidade de demanda;

$\checkmark$ Melhorar nível de serviço: proposto pelo autor com base em McCullen e Eagle (2015) e Bahu, Bironneau e Hovelaque (2019) que descreveram a busca por melhor nível de serviço como uma motivação para a implementação do DDMRP.

b) barreiras para implementação:

$\checkmark$ Falta de compartilhamento de informações entre departamentos: proposto pelo autor com base na teoria para implementação do DDMRP, em que a troca de informações é importante para definir parâmetros do método, como por exemplo o dimensionamento de buffers;

$\checkmark$ Falta de experiência dos funcionários com o sistema de produção da empresa: proposto pelo autor com base na afirmação de Velasco Acosta, Mascle e Baptiste (2019) que destacam que o 
DDMRP possui fatores subjetivos a escolha dos profissionais. $O$ que pode sofrer influência pela experiência dos mesmos;

$\checkmark$ Dificuldade na reconfiguração da produção (layout): proposto pelo autor com base em possíveis alterações na configuração do chão de fábrica para adaptação ao novo sistema e buffers;

$\checkmark$ Dificuldade em posicionar os buffers: segundo os autores do método DDMRP, Ptak e Smith (2016), seis fatores devem ser analisados para escolher esse posicionamento, e na interpretação do autor esses fatores podem ser subjetivos, o que pode criar dificuldades nas escolhas;

$\checkmark$ Dificuldade em dimensionar os buffers: proposto pelo autore para verificar a dificuldades dos profissionais em aplicar a formulação teórica para dimensionar os buffers e seus aspectos subjetivos;

$\checkmark$ Dificuldade em estabelecer o PAF (fator de ajuste planejado) para sazonalidade: proposto pelo autor com base em Lee e Rim (2019) que destacam que a subjetividade na determinação do PAF pode ser problemática;

$\checkmark$ Dificuldade em aplicar a gestão visual: proposto pelo autor a fim de verificar se ocorrem dificuldades em estabelecer a gestão visual para priorização e gestão de ordens;

$\checkmark$ Dificuldade em adaptar o DDMRP ao sistema de resposta à demanda adotado pela empresa: proposto pelo autor para verificar possíveis dificuldades em usar o DDMRP a diferentes tipos de resposta à demanda;

$\checkmark$ Incompatibilidade com o mercado de atuação da empresa: proposto pelo autor para verificar possíveis setores ou mercados em que o DDMRP não se encaixe bem, como por exemplo no caso da afirmação de Pekarcíková et al. (2019) que afirmaram dificuldades do DDMRP com longos lead time de entrega para matéria prima; 
c) fatores críticos de sucesso para implementação:

$\checkmark$ Adequação do DDMRP ao mercado da empresa: proposto pelo autor para testar a percepção dos profissionais quanto a adequação do DDMRP ao mercado que a empresa está inserida;

$\checkmark$ Adequação do DDMRP à filosofia da empresa: proposto pelo autor para avaliar se a filosofia da empresa é crítica na implementação do DDMRP, com sua filosofia de colocar a demanda real no centro das decisões;

$\checkmark$ Adequação do DDMRP ao tipo de resposta à demanda da empresa: proposto pelo autor para avaliar se o tipo de resposta à demanda é crítico no sucesso da implementação do DDMRP;

$\checkmark$ Experiência dos colaboradores com a empresa: proposto pelo autor com base em Velasco Acosta, Mascle e Baptiste (2019) que destacam que o DDMRP possui fatores subjetivos a escolha dos profissionais. O que, na interpretação do autor, pode sofrer influência pela experiência dos mesmos com a empresa;

$\checkmark$ Planejamento de longo prazo: proposto pelo autor a fim de avaliar a percepção da importância de planejar longo horizonte de tempo, pois o DDMRP representa uma mudança na filosofia da empresa. 


\section{CAPÍTULO 4 - APLICAÇÃO DA SURVEY FUZZY DELPHI}

Esse capítulo do trabalho é dedicado ao estudo survey da pesquisa. Primeiro, são tabulados os elementos de implementação, selecionados nos capítulos anteriores, para análise dos especialistas. Em seguida, é detalhada toda a metodologia usada para condução da pesquisa aplicada com a justificativa para a escolha do método e o passo a passo detalhado do Fuzzy Delphi. Posteriormente é feita a caracterização do grupo de especialistas e descrição do processo de condução da pesquisa.

Na seção 4.3 são apresentados os resultados obtidos pelas respostas dos especialistas ao questionário e o processamento dos dados pelo Fuzzy Delphi, bem como as respostas às questões abertas. Finalmente, na seção 4.4 é feita uma análise crítica e discutidas as implicações dos resultados.

\subsection{ELEMENTOS DE IMPLEMENTAÇÃO PARA O QUESTIONÁRIO}

O Quadro 4.1 apresenta o conjunto de potenciais motivações para implementação do DDMRP identificado na revisão bibliográfica e interpretado pelo autor, contendo pontos importantes para cadeias demand driven e fatores destacados do DDMRP em outras pesquisas do tema. Na bibliografia de implementação de sistemas de PCP, o termo em inglês "Driver" é utilizado para expressar motivos que levam a decisão para implementar um sistema de PCP.

Quadro 4.1 - Motivações para implementação do DDMRP.

\begin{tabular}{cc}
\hline Identificação & Motivação de implementação \\
\hline M1 & Redução / controle de inventário \\
\hline M2 & Redução de custo operacional \\
\hline M3 & Reduzir lead time da manufatura \\
\hline M4 & Reduzir / eliminar taxa de stock-out (quebras de estoques) \\
\hline M5 & Reduzir a instabilidade do sistema MRP \\
\hline M6 & Reduzir prazo de entrega \\
\hline M7 & Reduzir uso de capital de giro \\
\hline
\end{tabular}


Quadro 4.1 - Motivações para implementação do DDMRP.

\begin{tabular}{cc}
\hline Identificação & Motivação de implementação \\
\hline M8 & Aumentar agilidade / responsividade \\
\hline M9 & Aumentar flexibilidade \\
\hline M10 & Aumentar a eficiência \\
\hline M11 & Orientação à demanda \\
\hline M12 & Apoiar iniciativas Lean \\
\hline M13 & Adaptabilidade à ambientes de incerteza (demanda) \\
\hline M14 & Ajuste dinâmico de inventário (para a sazonalidade) \\
\hline M15 & Aplicar melhores práticas de mercado \\
\hline M16 & Melhorar priorização e sequenciamento de ordens \\
\hline M17 & Melhorar pontualidade de entrega \\
\hline M18 & Melhorar nível de serviço \\
\hline
\end{tabular}

Fonte: Proposto pelo autor.

O Quadro 4.2 apresenta as potenciais barreiras para implementação do DDMRP com base na bibliografia consultada de métodos de PCP (ERP/MRP e Lean) e pontos importantes na implementação do DDMRP a serem analisados no estudo aplicado.

Quadro 4.2 - Barreiras para implementação do DDMRP.

\begin{tabular}{cc}
\hline Identificação & Barreira de implementação \\
\hline B1 & Falta de conhecimento do método \\
\hline B2 & Falta de precisão nos dados \\
\hline B3 & Falta de suporte da alta gerência \\
\hline B4 & Falta de suporte do fornecedor do sistema \\
\hline B5 & Falta de comprometimento dos funcionários \\
\hline B6 & Falta de treinamento \\
\hline B7 & Falta de recursos humanos \\
\hline B8 & Falta de tempo disponível \\
\hline B9 & Falta de apoio de consultores externos
\end{tabular}

Falta de compartilhamento de informações entre

departamentos

B11

Falta de prazos e metas claras

Falta de experiência dos funcionários com o sistema de produção da empresa

B13 Dificuldade na reconfiguração da produção (layout) 
Quadro 4.2 - Barreiras para implementação do DDMRP.

\begin{tabular}{cc}
\hline Identificação & Barreira de implementação \\
\hline B14 & Dificuldade em posicionar os buffers \\
\hline B15 & Dificuldade em dimensionar os buffers \\
\hline B16 & Dificuldade em estabelecer o PAF (fator de ajuste planejado) \\
p17 & Dificuldade em aplicar a gestão visual \\
\hline B18 & Dificuldade em adaptar o DDMRP ao sistema de resposta à \\
B19 & Incomanda adotado pela empresa \\
\hline B20 & Incompatibilidade com o mercado de atuação da empresa \\
\hline B21 & Choque cultural \\
\hline B22 & Customizações requisitadas no sistema \\
\hline B23 & Custo elevado \\
\hline B24 & Complexidade do projeto / mudança \\
\hline B25 & Resistência a mudança \\
\hline
\end{tabular}

Fonte: Proposto pelo autor.

O Quadro 4.3 apresenta os fatores críticos de sucesso para implementação do método DDMRP com base na bibliografia de implementação de métodos de PCP (ERP/MRP e Lean). A implementação de métodos PCP possui pontos em comum que podem ser explorados nesse estudo de campo e novas questões podem ser identificadas.

Quadro 4.3 - Fatores críticos de sucesso para implementação do DDMRP.

\begin{tabular}{cc}
\hline Identificação & Fator crítico de sucesso para implementação \\
\hline FC1 & Apoio da alta gerência \\
\hline FC2 & Treinamento e educação \\
\hline FC3 & Planejamento e gestão de projeto \\
\hline FC4 & Planejamento de longo prazo \\
\hline FC5 & Suporte de consultores externos \\
\hline FC6 & Suporte do fornecedor do sistema \\
\hline FC7 & Disponibilidade de recursos \\
\hline FC8 & Precisão e integridade dos dados \\
\hline FC9 & Adequação do hardware e software \\
FC10 & Adequação do DDMRP ao mercado da empresa \\
\hline FC11 & Adequação do DDMRP à filosofia da empresa
\end{tabular}


Quadro 4.3 - Fatores críticos de sucesso para implementação do DDMRP.

\begin{tabular}{cc}
\hline Identificação & $\begin{array}{c}\text { Fator crítico de sucesso para implementação } \\
\text { fC12 }\end{array}$ \\
\hline FC13 & Metequação do DDMRP ao tipo de resposta à demanda da \\
\hline FC14 & Motivação e comprometimento da equipe \\
\hline FC15 & Comunicação e engajamento \\
\hline FC16 & Conhecimento técnico aprofundado do método \\
\hline FC17 & Compartilhamento de informações \\
\hline FC18 & Cultura organizacional proativa \\
\hline FC19 & Experiência dos colaboradores com a empresa \\
\hline
\end{tabular}

Fonte: Proposto pelo autor.

\subsection{METODOLOGIA FUZZY DELPHI}

\subsubsection{Justificativa pela escolha do método}

Para a realização da análise de dados foi selecionado o método Fuzzy Delphi para aplicação do questionário sobre os elementos de implementação do DDMRP. Esse método tem sido aplicado por pesquisadores na condução de pesquisas survey por ajudar a reduzir a incerteza de julgamentos de especialistas e garantir a qualidade de análises de pesquisas do tipo survey (BUI et al., 2020). Liu e Wang (2009) completam que esse método pode efetivamente reduzir o número de questionários e agilizar a convergência de opiniões.

Quanto à aplicabilidade do método Fuzzy Delphi para a proposição dessa pesquisa, pode-se perceber que ele já foi empregado em estudos anteriores similares. O Fuzzy Delphi foi usado por Hsu, Lee e Kreng (2010) e Stefano, Casarotto Filho e Duarte (2014) para seleção de fatores críticos de seleção, já em trabalhos como os de Bouzon et al. (2016), Dong e Huo (2017) e Bui et al. (2020) o método foi utilizado para identificação de barreiras de implementação de determinadas iniciativas de gestão. Já Liu e Wang (2009) utilizaram essa metodologia para identificar critérios de avaliação.

Dessa forma nota-se que o método proposto é adequado para lidar com as questões desta pesquisa, pois já foi empregado em situações 
similares e apresentou resultados consistentes. Na seção a seguir o método Fuzzy Delphi é apresentado e descrito como foi empregado nesse trabalho.

\subsubsection{O método Fuzzy Delphi}

O método Fuzzy Delphi foi apresentado inicialmente por Kaufmann e Gupta (1988) e posteriormente desenvolvido por Ishikawa et al. (1993). Deriva do método de tomada de decisão em grupo Delphi, proposto inicialmente por Dalkey e Helmer (1963), com o uso da teoria dos conjuntos fuzzy de Zadeh (1965).

A combinação dessas duas abordagens tinha o objetivo de melhorar os resultados alcançados, lidar com problemas de baixa convergência dos especialistas e reduzir os custos e o tempo de execução (GALO, 2018). Bui et al. (2020) completa esse raciocínio afirmando que o método Fuzzy Delphi apresenta a vantagem de reduzir o número de entrevistas e o tempo de investigação e oferece uma expressão mais completa do conhecimento dos especialistas.

Em situações reais, julgamentos podem não ser precisamente interpretados por valores quantitativos devido à imprecisão e natureza subjetiva do pensamento, julgamento e preferências humanas. Por isso, a aplicação da teoria fuzzy é usada para lidar com a imprecisão do pensamento humano (BOUZON et al., 2016).

Para a execução do método um passo a passo é realizado. A seguir são descritos esses passos (KUO; CHEN, 2008; STEFANO; CASAROTTO FILHO; DUARTE, 2014; HABIBI; JAHANTIGH; SARAFRAZI, 2015; BOUZON et al., 2016; GALO, 2018; BUI et al., 2020).

Passo 1: identificar e definir o espectro de fuzzificação das expressões linguísticas. Os números fuzzy mais usualmente aplicado são os triangulares, mas também é possível utilizar os trapezoidais. Para esse trabalho serão utilizados os triangulares que na escala de Likert são comumente usados de cinco ou sete termos linguísticos. O Quadro 4.4 apresenta a escala com cinco termos linguísticos, que é a escolhida para essa pesquisa. 
Quadro 4.4 - Escala Likert de cinco termos linguísticos para números fuzzy triangulares.

\begin{tabular}{ccccc}
\hline $\begin{array}{c}\text { Muito sem } \\
\text { importância }\end{array}$ & $\begin{array}{c}\text { Sem } \\
\text { importância }\end{array}$ & $\begin{array}{c}\text { Moderadamente } \\
\text { importante }\end{array}$ & $\begin{array}{c}\text { Importante } \\
\text { importante }\end{array}$ & $\begin{array}{c}\text { Muito } \\
\text { importante }\end{array}$ \\
\hline$(0 ; 0 ; 0,25)$ & $(0 ; 0,25 ; 0,5)$ & $(0,25 ; 0,5 ; 0,75)$ & $(0,5 ; 0,75 ; 1)$ & $(0,75 ; 1 ; 1)$ \\
\hline
\end{tabular}

Passo 2: Deve-se organizar um painel de especialistas para a aplicação dos questionários, de modo que cada um expresse sua opinião sobre o grau de importância ou concordância com cada critério pertencente a um conjunto $S$. O resultado dessa avaliação dos especialistas é denominado $R_{i k}, i \in S$, para todo critério $i$ avaliado por todo especialista $k$, com $R_{i k}=$ $\left(l_{i k}, m_{i k}, u_{i k}\right)$, assim a avaliação dos especialistas é convertida em valores fuzzy.

Passo 3: Deve-se organizar os dados coletados a partir do questionário e agregar a opinião de todos os especialistas para cada critério $i$, em um índice $O_{i}=\left(L_{i}, M_{i}, U_{i}\right)$.

$\mathrm{Na}$ literatura existem diversas maneiras de realizar a agregação, a forma mais simples é pela média aritméticas das avaliações.

$$
O_{i}=\left(\frac{\sum l_{i k}}{k}, \frac{\sum m_{i k}}{k}, \frac{\sum u_{i k}}{k}\right)
$$

Outra forma encontrada na literatura é pelo mínimo valor de $l_{i k}$, média aritmética das avaliações de $m_{i k}$, e o valor máximo de $u_{i k}$.

$$
O_{i}=\left(\operatorname{mín}\left[l_{i k}\right], \frac{\sum m_{i k}}{k}, \operatorname{máx}\left[u_{i k}\right]\right)
$$

Também é possível através da média geométrica das avaliações de $m_{i k}$

$$
O_{i}=\left(\operatorname{mín}\left[l_{i k}\right],\left[\prod_{1}^{k} m_{i k}\right]^{1 / k}, \operatorname{máx}\left[u_{i k}\right]\right)
$$


A escolha do método de agregação depende da visão do pesquisador. O uso dos métodos por valores mínimos e máximos leva a considerar a dispersão máxima das opiniões, porém um problema associado a essa escolha é que uma opinião otimista ou pessimista afeta fortemente os resultados (HABIBI; JAHANTIGH; SARAFRAZI, 2015). Desta forma, para essa pesquisa optou-se por escolher a agregação pela média aritmética das avaliações.

Passo 4: Após a agregação das avaliações dos especialistas os números fuzzy devem ser desfuzzificados para números crisp $\left(Z_{i}\right)$ para serem interpretados. Na literatura do tema são relatados vários métodos, Habibi, Jahantigh e Sarafrazi (2015) sugerem a seguinte forma:

$$
Z_{i}=\operatorname{máx}\left(x_{m}^{1}, x_{m}^{2}, x_{m}^{3}\right)
$$

Com os valores $x_{m}^{1}, x_{m}^{2}, x_{m}^{3}$ sendo:

$$
\begin{gathered}
x_{m}^{1}=\frac{L_{i}+M_{i}+U_{i}}{3} \\
x_{m}^{2}=\frac{L_{i}+2 M_{i}+U_{i}}{4} \\
x_{m}^{3}=\frac{L_{i}+4 M_{i}+U_{i}}{6}
\end{gathered}
$$

Outro método de desfuzzificação é pelo Centro de Área (COA).

$$
Z_{i}=\frac{\left(U_{i}-L_{i}\right)+\left(M_{i}-L_{i}\right)}{3}+L_{i}
$$

Nessa pesquisa foi adotado o método de desfuzzificação proposto por Habibi, Jahantigh e Sarafrazi (2015).

Passo 5: Por fim deve-se analisar e filtrar os critérios de avaliação por meio de um limite $\alpha$, de forma que se $Z_{i} \geq \alpha$ a alternativa é selecionada, ou 
seja, para o caso do trabalho o elemento de implementação é considerado importante/relevante; caso contrário se $Z_{i}<\alpha$, a alternativa é eliminada.

$\mathrm{Na}$ literatura são relatadas várias abordagens para a definição desse limite $\alpha$. Bui et al. (2020) define o limite como a média dos $Z_{i}$, sendo, portanto:

$$
\alpha=\sum_{k=1}^{k} Z_{i} /_{k}
$$

Por esse método os critérios que forem menores que a média são descartados, caso contrário são aceitos.

Outra metodologia para definir o limite é relatada e usada por Manakandan et al. (2017). Por esse método um critério é aceito se satisfazer três requisitos. O primeiro requisito é $d_{m \text { éd }} \leq 0,2$ sendo $d$ calculado pela seguinte formula:

$$
d_{i k}(\bar{O}, \bar{R})=\sqrt{\frac{1}{3}\left[\left(\bar{l}_{i}-l_{i k}\right)^{2}+\left(\bar{m}_{i}-m_{i k}\right)^{2}+\left(\bar{u}_{i}-u_{i k}\right)^{2}\right]} \text { (Equação 23) }
$$

O valor $d$ deve ser calculado para cada critério e para cada avaliação de cada especialista. Então encontra-se o valor médio de $d$ para cada critério.

$$
d_{i_{\text {méd }}}=\sum d_{i k}(\bar{O}, \bar{R}) /_{n^{\circ} \text { de especialistas }}
$$

O segundo requisito é avaliado pelo cálculo do índice de consenso dos especialistas da seguinte forma para cada critério:

$$
\text { Consenso }_{i}(\%)=\frac{n^{\circ} \text { de } d_{i k}(\bar{O}, \bar{R}) \leq 0,2}{n^{\circ} \text { de especialistas }}
$$

Por fim é feito um rank com os valores crisp de cada critério após a desfuzzificação. Para a análise três requisitos devem ser satisfeitos para o critério ser aceito, o valor $d_{i_{m} \text { éd }}$ deve ser menor ou igual a 0,2; o índice de 
consenso deve ser maior ou igual a 75\%; e uma análise do rank dos valores crisp é feita.

O trabalho adotou a metodologia proposta por Manakandan et al. (2017), com o valor crisp aceito como sendo maior ou igual a 0,7 .

\subsubsection{Processo de aplicação do questionário e caracterização do painel de especialistas}

A validação do questionário e a escolha dos especialistas que responderão a pesquisa configuram uma das etapas mais importantes do processo de pesquisa pelo método Fuzzy Delphi.

Em acordo com Kuo e Chen (2008) e Bui et al. (2020), o questionário foi previamente analisado e validado por dois especialistas antes de ser submetido para os especialistas que iriam responde-lo. Essa avaliação prévia é importante para modificar questões que não estejam claras e realizar correções a fim de aperfeiçoar a ferramenta de coleta de dados.

Os dois especialistas selecionados para essa etapa possuem grande experiência na área de gestão de operações e conhecimento prévio sobre o método DDMRP, ambos possuem certificação emitida pelo instituto que visa divulgar e treinar profissionais para atuar com o método. 0 especialista 1 possui 25 anos de experiência com gestão de operações e 8 anos com 0 DDMRP, atuando como consultor em implantação e desenvolvendo soluções tecnológicas na gestão da operação do DDMRP. O especialista 2 possui 30 anos de experiência com gestão de operações e 3 anos com o DDMRP, atuando com ensino e treinamento empresarial do DDMRP.

Ambos os especialistas validaram o questionário sem sugerirem alterações relevantes. O questionário pode ser verificado consultando o Apêndice $A$ nesse trabalho. Para o envio do questionário aos especialistas foi utilizado a ferramenta online SurveyMonkey.

É fundamental para obter resultados consistentes uma criteriosa escolha do grupo de especialistas que irão compor o painel, assim como o número de pessoas que responderam ao questionário. Consultando a literatura de trabalhos que utilizaram o método Fuzzy Delphi encontra-se a recomendação para a dimensão do grupo de especialistas ser entre 10 a 50 
indivíduos. Brás e Marques (2018) recomenda para o método Delphi, origem do Fuzzy Delphi, pelo menos dez pessoas.

Bogner, Litting e Menz (2009) afirmam que para o método Delphi atingir alto nível de competência, eliminando e reduzindo ao máximo problemas de ponto de vista relacionados com os interesses e o estreitamento de perspectivas decorrente da especialização, os especialistas devem ser de vários campos; pesquisadores, negócios, administradores, consultores entre outros. Em conformidade com essa recomendação o trabalho buscou selecionar respondentes de vários ramos industriais, consultores e pesquisadores acadêmicos.

Bouzon et al. (2016) identificou no seu trabalho outros autores que utilizaram o método Fuzzy Delphi, sendo que Hsu, Lee e Kreng (2010) selecionaram nove especialistas, Bueno e Salmeron (2008) selecionaram dez, e Ma et al. (2011) selecionaram treze especialistas. Em seu próprio trabalho Bouzon et al. (2016) obtiveram respostas de dez especialistas. Dessa forma, esse trabalho ultrapassou com folga o número mínimo de respostas recomendada, com trinta e três retornos por parte dos especialistas selecionados.

A seguir estão os dados estatísticos do grupo de especialistas que permitem a caracterização da amostra de profissionais selecionados para responderem o questionário Fuzzy Delphi. Desta forma, fica evidente a aderência por parte da pesquisa às recomendações.

O primeiro aspecto estatístico aqui relatado é o tempo de experiência com o DDMRP por parte dos especialistas. Os dados estão agrupados por faixas de tempo conforme o Quadro 4.5 a seguir, dos trinta e três respondentes apenas três não indicaram o tempo de experiência com o DDMRP.

Quadro 4.5 - Tempo de experiência dos especialistas com o DDMRP.

\section{Tempo de Experiência (anos) \\ Quantidade de Especialistas}

\begin{tabular}{cc}
\hline $0-2$ & 6 \\
\hline $2-4$ & 13 \\
\hline $4-6$ & 6 \\
\hline $6-8$ & 4 \\
\hline $10-12$ & 1
\end{tabular}

Fonte: Proposto pelo autor. 
A próxima estatística da amostra de especialistas é sobre o tempo de experiência com gestão de operações. Assim como o aspecto anterior os dados estão agrupados por faixas de tempo conforme o Quadro 4.6. Dos trinta e três especialistas apenas quatro não responderam o tempo de experiência com gestão de operações.

Quadro 4.6 - Tempo de experiência dos especialistas com gestão de operações.

\section{Tempo de Experiência (anos)}

\begin{tabular}{cl}
\hline $0-5$ & 2 \\
\hline $5-10$ & 6 \\
\hline $10-15$ & 6 \\
\hline $15-20$ & 4 \\
\hline $20-25$ & 6 \\
\hline $25-30$ & 2 \\
\hline $30-35$ & 3
\end{tabular}

Fonte: Proposto pelo autor.

Outro dado relevante para a pesquisa é a abrangência dos setores industriais que os respondentes atuam, sendo importante para evitar vieses de determinados setores ou grupos de especialistas com interesses particulares que possam interferir nas respostas e avaliações. O Quadro 4.7 mostra os dados, todos os respondentes identificaram os setores de atuação.

Quadro 4.7 - Setores de atuação dos especialistas.

\begin{tabular}{cc}
\hline Setores de atuação & Quantidade de Especialistas \\
\hline Alimentos e bebidas & 7 \\
\hline Consultoria e treinamento & 5 \\
\hline Outros & 4 \\
\hline Industria mecânica & 4 \\
\hline Farmacêutico e cosmético & 3 \\
\hline Plástico & 2 \\
\hline Soluções tecnológicas & 2 \\
\hline Bens de consumo & 2 \\
\hline Automotivo & 2 \\
\hline Academia (Universidades) & 2 \\
\hline
\end{tabular}

Fonte: Proposto pelo autor. 
Dentro de outros estão os setores: siderúrgico, têxtil, químico e ensaios não destrutivos, com um especialista em cada. O setor de soluções tecnológicas são especialistas que atuam na implantação de sistemas para controle e gestão do DDMRP.

Outro ponto importante a se destacar é a estratégia de resposta à demanda adotada pela empresa. Para esse dado é importante destacar que algumas empresas utilizam mais de uma estratégia para diferentes clientes e linhas de negócios, além disso dos trinta e três especialistas que responderam à pesquisa, nove não responderam essa pergunta pois atuam em setores não produtivos (consultoria, soluções tecnológicas e academia).

Dessa forma as estratégias de resposta à demanda citadas são as seguintes, conforme o Quadro 4.8.

Quadro 4.8 - Estratégias de resposta à demanda utilizadas.

\begin{tabular}{cc} 
Estratégia de resposta à demanda & Quantidade de vezes citadas \\
MTS & 16 \\
MTO & 13 \\
ATO & 4 \\
\hline
\end{tabular}

Fonte: Proposto pelo autor.

Outra questão feita aos especialistas foi qual era o sistema de gerenciamento de produção utilizado antes do DDMRP, para as empresas que já estão utilizando o DDMRP. Dos trinta e três especialistas consultados quinze não responderam ou a questão não era aplicável. Dos que responderam, tem-se os seguintes dados, conforme o Quadro 4.9.

Quadro 4.9 - Sistemas utilizados antes do DDMRP.

\section{Sistema utilizado antes do DDMRP Quantidade de vezes citados}

\begin{tabular}{cc}
\hline MRP & 16 \\
\hline TOC & 2 \\
\hline Mín-Máx & 1 \\
\hline
\end{tabular}

Fonte: Proposto pelo autor.

Destaca-se que um dos entrevistados indicou que a empresa utilizava dois sistemas, MRP e TOC, antes da implementação do DDMRP. 
Ponto também questionado, é sobre há quanto tempo a empresa em que o respondente atua utiliza o DDMRP como sistema de gestão, se aplicável. As respostas foram agrupadas em faixas temporais, em anos, e estão apresentadas no Quadro 4.10 a seguir.

Quadro 4.10 - Tempo em que a empresa do respondente adota o DDMRP.

\section{Tempo que a empresa adota o Quantidade de vezes citados} DDMRP (anos)

\begin{tabular}{ll}
\hline $0-1$ & 1 \\
\hline $1-2$ & 7 \\
\hline $2-3$ & 5 \\
\hline $3-4$ & 5 \\
\hline $6-7$ & 2
\end{tabular}

Fonte: Proposto pelo autor.

A última das estatísticas de caracterização do painel de especialistas escolhidos para responderem as questões identifica o país de atuação dos profissionais. Uma boa variedade evita resultados enviesados por características particulares regionais. O Quadro 4.11 apresenta esses dados.

Quadro 4.11 - País de atuação do especialista.

\begin{tabular}{cc}
\hline País de atuação do especialista & Quantidade de especialistas \\
\hline Colômbia & 15 \\
\hline Brasil & 7 \\
\hline Suíça & 3 \\
\hline México & 3 \\
\hline China & 1 \\
\hline África do Sul & 1 \\
\hline Canadá & 1 \\
\hline Reino Unido & 1 \\
\hline Indonésia & 1 \\
\hline
\end{tabular}

Fonte: Proposto pelo autor. 


\subsection{RESULTADOS}

Nessa seção serão apresentados os resultados da pesquisa. Primeiro, serão reportados os resultados da pesquisa que utilizaram o método Fuzzy Delphi a partir da lista de motivações para implementação do DDMRP, barreiras para implementação e fatores críticos de sucesso previamente levantados com a pesquisa bibliográfica do trabalho. Em seguida serão apresentados os resultados das questões abertas aos especialistas para a checagem de outros elementos observados através da experiência empírica dos mesmos com as implementações em que atuaram.

\subsubsection{Resultados obtidos pelo Fuzzy Delphi}

Os dados brutos da pesquisa com as respostas dos especialistas para as questões em escala Likert do questionário foram preservados por questão de confidencialidade. No Apêndice B pode-se consultar os dados já agregados conforme descrito no Passo 3 da seção 4.2.2, o processo de desfuzzificação, o cálculo dos valores " $d$ " e o índice de consenso conforme o Passo 5.

Após coletar as respostas dos especialistas do painel por meio da survey, o passo 2 é a conversão das respectivas respostas em números fuzzy triangulares pela escala Likert para cada critério analisado. Em seguida, as próximas etapas do processo são os passos 3 e 4, em que as respostas dos especialistas fuzzificadas são agregadas para cada critério e então transformadas em valores crisp.

A seguir, os valores crisp calculados por esse processo descrito na seção 4.2.2 são apresentados em conjunto com o resultado dos valores $d_{\text {méd }}$ e o índice de consenso. Assim, são encontrados cada elemento que satisfazem os critérios definidos pela pesquisa para serem considerados relevantes no processo de implementação do DDMRP.

Os valores crisp $\left(Z_{i}\right)$ estão apresentados em ordem decrescente facilitando assim a visualização dos que foram avaliados como mais importantes/relevantes com a respectiva identificação do aspecto de implementação (motivação, barreiras, fatores críticos de sucesso) e os

valores $d_{m e ́ d}$ e do índice de consenso. Assim, avaliando quais fatores foram 
identificados como relevantes pelos especialistas por meio do método Fuzzy Delphi e quais atingiram o índice mínimo de consenso exigido.

A interpretação das Tabelas 4.1, 4.2 e 4.3 é realizada da seguinte forma: a primeira coluna identifica o aspecto analisado de acordo com os Quadros 4.1, 4.2 e 4.3; a segunda coluna é o cálculo do valor crisp $\left(Z_{i}\right)$; a terceira coluna é o valor $d_{\text {méd }}$ para cada elemento analisado, esse valor é uma forma de expressar a dispersão média das respostas dos especialistas; a quarta coluna indica o índice de consenso, basicamente ele identifica a porcentagem de valores $d_{\text {méd }}$ que estão abaixo do limite estabelecido, indicando quantos valores $d$ estão abaixo do limite proposto; a quinta coluna de aceitabilidade indica se o fator analisado foi aceito pela metodologia aplicada pela pesquisa, para ser aceito ele deve ter o valor crisp maior ou igual a 0,7, o $d_{\text {méd }}$ deve ser menor ou igual a 0,2 e o índice de consenso maior ou igual a 0,75 ; por último a sexta coluna indica se o consenso foi atingido, expressando se o $d_{m e ́ d}$ é menor ou igual a 0,2 e o índice de consenso maior ou igual a 0,75 , pois pode ocorrer de uma fator ser considerado não relevante pelo valor crisp e haver consenso sobre esse fato.

Essas definições foram estabelecidas pelo autor de acordo com o proposto por Manakandan et al. (2017) para o índice de consenso e $d_{\text {méd }}$ e de acordo com Habibi, Jahantigh e Sarafrazi (2015) para o valor crisp, pois o valor de 0,7 situa-se nos termos linguísticos "importante/relevante" e "muito importante/muito relevante".

Nesse sentido, a Tabela 4.1 apresenta essa análise das motivações para implementação do DDMRP.

Tabela 4.1 - Análise das motivações para implementação do DDMRP.

\begin{tabular}{cccccc}
\hline Ident. & $\boldsymbol{Z}_{\boldsymbol{i}}$ & $\boldsymbol{d}_{\boldsymbol{m} \text { é }}$ & Índice consenso & Aceitabilidade & Consenso \\
\hline M18 & 0,902 & 0,081 & 1,000 & ACEITO & SIM \\
\hline M4 & 0,862 & 0,139 & 0,848 & ACEITO & SIM \\
\hline M1 & 0,847 & 0,124 & 0,909 & ACEITO & SIM \\
\hline M17 & 0,847 & 0,124 & 0,909 & ACEITO & SIM \\
\hline M14 & 0,817 & 0,158 & 0,818 & ACEITO & SIM \\
\hline M7 & 0,804 & 0,156 & 0,818 & ACEITO & SIM \\
\hline M8 & 0,802 & 0,123 & 0,909 & ACEITO & SIM \\
\hline M11 & 0,788 & 0,183 & 0,758 & ACEITO & SIM \\
\hline
\end{tabular}


Tabela 4.1 - Análise das motivações para implementação do DDMRP.

\begin{tabular}{cccccc}
\hline Ident. & $\boldsymbol{Z}_{\boldsymbol{i}}$ & $\boldsymbol{d}_{\boldsymbol{m} \text { é }}$ & Índice consenso & Aceitabilidade & Consenso \\
\hline M13 & 0,778 & 0,156 & 0,818 & ACEITO & SIM \\
\hline M9 & 0,760 & 0,129 & 0,848 & ACEITO & SIM \\
\hline M16 & 0,750 & 0,162 & 0,758 & ACEITO & SIM \\
\hline M3 & 0,701 & 0,206 & 0,545 & NÃO ACEITO & NÃO \\
\hline M10 & 0,696 & 0,161 & 0,727 & NÃO ACEITO & NÃO \\
\hline M5 & 0,687 & 0,212 & 0,545 & NÃO ACEITO & NÃO \\
\hline M6 & 0,678 & 0,194 & 0,636 & NÃO ACEITO & NÃO \\
\hline M2 & 0,636 & 0,182 & 0,727 & NÃO ACEITO & NÃO \\
\hline M15 & 0,601 & 0,222 & 0,606 & NÃO ACEITO & NÃO \\
\hline M12 & 0,497 & 0,200 & 0,303 & NÃO ACEITO & NÃO \\
\hline
\end{tabular}

Fonte: Proposto pelo autor.

A Tabela 4.2 apresenta a análise para as barreiras de implementação do DDMRP.

Tabela 4.2 - Análise das barreiras de implementação do DDMRP.

\begin{tabular}{cccccc}
\hline Ident. & $\boldsymbol{Z}_{\boldsymbol{i}}$ & $\boldsymbol{d}_{\boldsymbol{m} \text { é }}$ & Índice consenso & Aceitabilidade & Consenso \\
\hline B25 & 0,744 & 0,171 & 0,424 & NÃO ACEITO & NÃO \\
\hline B3 & 0,716 & 0,239 & 0,152 & NÃO ACEITO & NÃO \\
\hline B1 & 0,715 & 0,186 & 0,333 & NÃO ACEITO & NÃO \\
\hline B21 & 0,679 & 0,195 & 0,606 & NÃO ACEITO & NÃO \\
\hline B5 & 0,650 & 0,232 & 0,515 & NÃO ACEITO & NÃO \\
\hline B6 & 0,641 & 0,234 & 0,515 & NÃO ACEITO & NÃO \\
\hline B2 & 0,628 & 0,249 & 0,485 & NÃO ACEITO & NÃO \\
\hline B22 & 0,607 & 0,189 & 0,697 & NÃO ACEITO & NÃO \\
\hline B24 & 0,597 & 0,222 & 0,545 & NÃO ACEITO & NÃO \\
\hline B11 & 0,583 & 0,255 & 0,455 & NÃO ACEITO & NÃO \\
\hline B8 & 0,564 & 0,193 & 0,667 & NÃO ACEITO & NÃO \\
\hline B18 & 0,563 & 0,252 & 0,485 & NÃO ACEITO & NÃO \\
\hline B10 & 0,549 & 0,217 & 0,273 & NÃO ACEITO & NÃO \\
\hline B14 & 0,528 & 0,221 & 0,333 & NÃO ACEITO & NÃO \\
\hline B16 & 0,523 & 0,252 & 0,182 & NÃO ACEITO & NÃO \\
\hline B7 & 0,520 & 0,175 & 0,424 & NÃO ACEITO & NÃO \\
\hline B17 & 0,513 & 0,186 & 0,364 & NÃO ACEITO & NÃO \\
\hline B19 & 0,508 & 0,226 & 0,303 & NÃO ACEITO & NÃO \\
\hline B12 & 0,503 & 0,194 & 0,303 & NÃO ACEITO & NÃO \\
\hline B15 & 0,499 & 0,219 & 0,303 & NÃO ACEITO & NÃO \\
\hline B4 & 0,497 & 0,270 & 0,212 & NÃO ACEITO & NÃO \\
\hline B13 & 0,475 & 0,182 & 0,455 & NÃO ACEITO & NÃO \\
\hline B9 & 0,470 & 0,217 & 0,273 & NÃO ACEITO & NÃO \\
\hline
\end{tabular}


Tabela 4.2 - Análise das barreiras de implementação do DDMRP.

\begin{tabular}{cccccc}
\hline Ident. & $\boldsymbol{Z}_{\boldsymbol{i}}$ & $\boldsymbol{d}_{\boldsymbol{m} \text { éd }}$ & Índice consenso & Aceitabilidade & Consenso \\
\hline B23 & 0,409 & 0,185 & 0,788 & NÃO ACEITO & SIM \\
\hline B20 & 0,341 & 0,208 & 0,576 & NÃO ACEITO & NÃO \\
\hline
\end{tabular}

Fonte: Proposto pelo autor.

A Tabela 4.3 apresenta a análise para os fatores críticos de sucesso para implementação do DDMRP.

Tabela 4.3 - Análise dos fatores críticos de sucesso para implementação do DDMRP.

\begin{tabular}{cccccc}
\hline Ident. & $\boldsymbol{Z}_{\boldsymbol{i}}$ & $\boldsymbol{d}_{\boldsymbol{m} \text { é }}$ & Índice consenso & Aceitabilidade & Consenso \\
\hline FC1 & 0,920 & 0,061 & 1,000 & ACEITO & SIM \\
\hline FC2 & 0,908 & 0,075 & 1,000 & ACEITO & SIM \\
\hline FC15 & 0,842 & 0,117 & 0,939 & ACEITO & SIM \\
\hline FC13 & 0,833 & 0,133 & 0,909 & ACEITO & SIM \\
\hline FC14 & 0,831 & 0,106 & 0,970 & ACEITO & SIM \\
\hline FC16 & 0,826 & 0,141 & 0,848 & ACEITO & SIM \\
\hline FC8 & 0,811 & 0,166 & 0,848 & ACEITO & SIM \\
\hline FC3 & 0,782 & 0,119 & 0,848 & ACEITO & SIM \\
\hline FC5 & 0,758 & 0,153 & 0,758 & ACEITO & SIM \\
\hline FC12 & 0,736 & 0,165 & 0,394 & NÃO ACEITO & NÃO \\
\hline FC6 & 0,723 & 0,171 & 0,455 & NÃO ACEITO & NÃO \\
\hline FC7 & 0,717 & 0,150 & 0,455 & NÃO ACEITO & NÃO \\
\hline FC17 & 0,710 & 0,159 & 0,455 & NÃO ACEITO & NÃO \\
\hline FC18 & 0,707 & 0,195 & 0,576 & NÃO ACEITO & NÃO \\
\hline FC9 & 0,688 & 0,167 & 0,727 & NÃO ACEITO & NÃO \\
\hline FC11 & 0,682 & 0,162 & 0,758 & NÃO ACEITO & SIM \\
\hline FC4 & 0,674 & 0,167 & 0,758 & NÃO ACEITO & SIM \\
\hline FC19 & 0,655 & 0,152 & 0,848 & NÃO ACEITO & SIM \\
\hline FC10 & 0,636 & 0,197 & 0,667 & NÃO ACEITO & NÃO \\
\hline Font
\end{tabular}

Fonte: Proposto pelo autor.

Dessa forma, as seguintes motivações para implementação do DDMRP foram avaliadas como importantes e tiveram consenso entre os especialistas (em ordem decrescente do valor crisp):
a) M18 - Melhorar nível de serviço;
b) M4 - Reduzir / eliminar taxa de stock-out (quebras de estoques);
c) M1 - Redução / controle de inventário;
d) M17 - Melhorar pontualidade de entrega; 
e) M14 - Ajuste dinâmico de inventário (para a sazonalidade);

f) M7 - Reduzir uso de capital de giro;

g) M8 - Aumentar agilidade / responsividade;

h) M11 - Orientação à demanda;

i) M13 - Adaptabilidade à ambientes de incerteza (demanda);

j) M9 - Aumentar flexibilidade;

k) M16 - Melhorar priorização e sequenciamento de ordens.

Para as barreiras e dificuldades de implementação, nenhuma foi considerada relevante pelos especialistas e houve um único consenso: que a barreira "B23 - Custo elevado" não é relevante, ou seja, os especialistas avaliaram que o custo de implementação não é uma barreira para a implementação e houve um consenso pelos especialistas a respeito dessa análise.

Por fim, os seguintes fatores críticos de sucesso para implementação do DDMRP foram considerados importantes com consenso dos respondentes da pesquisa:
a) FC1 - Apoio da alta gerência;
b) FC2 - Treinamento e educação;
c) FC15 - Comunicação e engajamento;
d) FC13 - Metas e objetivos claros;
e) FC14 - Motivação e comprometimento da equipe;
f) FC16 - Conhecimento técnico aprofundado do método;
g) FC8 - Precisão e integridade dos dados;
h) FC3 - Planejamento e gestão de projeto;
i) FC5 - Suporte de consultores externos.

Adicionalmente, houve um consenso que os fatores "FC11 - Adequação do DDMRP à filosofia da empresa", "FC4 - Planejamento de longo prazo" e "FC19 - Experiência dos colaboradores com a empresa" não são fatores críticos de sucesso para a implementação.

Na seção 4.4 Análise e implicação dos resultados, os resultados serão explorados e discutidos mais profundamente. 


\subsubsection{Resultados das questões abertas}

As questões abertas ficaram opcionais para os especialistas responderem se eles observaram ou avaliaram novos fatores durante a implementação que não foram citados nas questões analisadas pelo Fuzzy Delphi. Dos trinta e três especialistas que responderam à pesquisa, dezessete responderam pelo menos uma das três questões abertas, com alguns citando mais de um fator para cada pergunta.

Para agrupar as respostas das questões abertas foram utilizadas as técnicas de análise de conteúdo e análise semântica. A análise de conteúdo consiste em uma análise interpretativa de texto por meio de decomposição do discurso e reconstrução racional da ideia central com a finalidade de criar categorias. Já a análise semântica avalia os significados de palavras e frases para criar categorias. Ambas são procedimentos sistemáticos de reducionismo para identificar a dimensionalidade do atributo (MAYRING, 2010; HENKEL, 2017).

Desta forma, pode-se agrupar respostas similares em categorias, facilitando a análise e apresentação dos resultados. Posteriormente na seção 4.4 os resultados serão analisados e discutidos e algumas respostas e percepções dos respondentes serão mais aprofundadas.

A seguir, estão os fatores de implementação por eles citados, separados por motivações, barreiras e fatores críticos de sucesso para implementação do DDMRP.

- Motivações:

a. reduzir o uso de previsões de demanda, utilizar a demanda real (4 menções);

b. praticidade, sistema integrado ( 2 menções);

c. visão sistêmica (2 menções);

d. promover mudança cultural ( 2 menções);

e. reduzir o efeito chicote na cadeia de suprimentos (1 menção);

f. apoiar estratégia omnichannel na gestão de estoques (1 menção);

g. usar a mesma estratégia que clientes (1 menção);

h. trocar o sistema de PCP anteriormente utilizado (1 menção);

i. reduzir o tempo de processamento de dados (1 menção); 
j. adaptar-se a um ambiente de manufatura em evolução (1 menção);

k. eliminar a distribuição bimodal de inventário (1 menção);

I. introduzir a cultura do fluxo (1 menção);

m. comunicação entre os elos da cadeia (1 menção).

- Barreiras:

a. falta de priorização por concorrência com outros projetos (1 menção);

b. orçamento de TI limitado (1 menção);

c. dificuldade em estabelecer cronograma de implementação (1 menção);

d. dificuldade em conectar o design funcional com a implementação do software (1 menção);

e. conflito ao colocar a demanda real como fator de decisão (1 menção);

f. resistência do setor de TI e da matriz com novas tecnologias ( 1 menção);

g. dificuldade em trocar o foco do custo para o fluxo (1 menção);

h. dificuldade em conectar os sistemas com parceiros externos (1 menção);

i. barreiras culturais ( 1 menção);

j. dificuldade na aplicação em ambientes com longo tempo de ciclo e alta variabilidade (1 menção).

- Fatores críticos de sucesso:

a. adoção de novos KPI's (2 menções);

b. gestão da mudança (1 menção);

c. alinhamento com outras diretrizes estratégicas (1 menção);

d. empresa ser aberta a novidades (1 menção);

e. foco na visão holística (1 menção);

f. acompanhamento pós implementação (1 menção).

Todas essas menções serão mais aprofundadas e exploradas na seção 4.4 a seguir. 


\subsection{ANÁLISE E IMPLICAÇÃO DOS RESULTADOS}

\subsubsection{Análise das motivações}

Inicialmente serão feitas as análises dos resultados produzidos pelo método Fuzzy Delphi. Começando pelas motivações, que são os fatores que levaram as empresas a buscarem o DDMRP como solução para problemas enfrentados ou como um método que promovesse melhorias na gestão da produção. Os dois fatores com maior relevância foram "M18 - Melhorar nível de serviço" e "M4 - reduzir/eliminar taxa de stock-out", que podem ser considerados relacionados, uma vez que quebras de estoques prejudicam 0 nível de serviço.

Vários autores que pesquisaram o DDMRP relatam que o método reduz as taxas de stock-out e melhora o nível de serviço (KORTABARRIA et al., 2018; MICLO et al., 2019b; VELASCO ACOSTA; MASCLE; BAPTISTE, 2019). Dessa forma, é esperado que novas empresas se interessem pelo método por esses fatores. Além disso, como visto na amostra de empresas, grande parte utilizava o MRP anteriormente.

A próxima motivação avaliada como importante foi a "M1 Redução/controle de inventário". O DDMRP utiliza buffers dinâmicos para controle de estoques intermediários na produção, o que proporciona maior controle e limite para o tamanho dos estoques formados. Além disso, assim como visto na literatura do MRP, um dos problemas desse método é a criação de estoques quando há alterações nas ordens de produção, o que em ambientes de imprevisibilidade de demanda com produção por previsão acaba sendo recorrente. Dessa forma, um método que altere essa lógica e reduza o nível de inventário torna-se atrativo.

A necessidade de garantir a pontualidade da entrega em um ambiente de maior dificuldade de programação de produção se torna um desafio, por isso o DDMRP utiliza buffers estrategicamente posicionados para proteger o fluxo. Essa atratividade do método também foi destacada por Bahu, Bironneau e Hovelaque (2019) e destacada pelos especialistas consultados na forma da motivação "M17 - Melhorar pontualidade de entrega".

A quinta motivação, "M14 - Ajuste dinâmico de inventário (para sazonalidade)" foi apontada como uma das mais importantes pelos 
especialistas, pois ela propicia um ajuste dinâmico dos buffers contribuindo para redução de inventário e "M7 - Reduzir uso do capital de giro", que é outra motivação apontada pelos especialistas, dependendo do momento de vendas do produto.

"M8 - Aumentar agilidade/responsividade" configura-se como um dos principais motivadores. Aliado a "M9 - Aumentar flexibilidade", que foi outra motivação avaliada como importante pelos especialistas, é capaz de proporcionar vantagem competitiva para as empresas, esse entendimento já era relatado por Stalk (1988). Em um estudo de caso, Kortabarria et al. (2018) identificou que o DDMRP aprimorou a agilidade e Miclo (2016) em seu estudo por simulação, concluiu que o DDMRP aumentou a flexibilidade do sistema, esses relatos podem criar novos interessados em adotar o método.

Outra motivação avaliada como importante é a "M11 - Orientação a demanda". Ela se configura pôr as empresas nesse ambiente de imprevisibilidade desejarem trocar a lógica de se produzir por previsão para buscar seguir à demanda real dos clientes. Kortabarria et al. (2018) apresenta como resultado de seu estudo de caso que o DDMRP reduziu a incerteza gerada pela previsão consideravelmente. Os especialistas, assim, avaliam que os efeitos benéficos de trocar a lógica da previsão por acompanhar a demanda faz essa motivação como importante.

Bahu, Bironneau e Hovelaque (2019) introduzem seu trabalho destacando que o ambiente industrial atualmente é caracterizado por incertezas de demanda, volume e diversidade. Assim, os especialistas consultados seguiram entendimento similar e destacaram que um sistema de PCP capaz de se adaptar a incertezas é importante.

Por último, foi destacado como importante a motivação "M16 Melhorar priorização e sequenciamento de ordens". Bahu, Bironneau e Hovelaque (2019) indicam como motivação a simplicidade do método, por sua gestão visual, o que pode ser associado à facilidade de identificação na priorização da produção, utilizando o código de cores para necessidade de produção.

Com relação as questões abertas, quatro especialistas relataram o desejo das empresas em reduzir o uso de previsões e passar a seguir a demanda real. Essa motivação é consonante com a "M11 - Orientação à demanda", que foi uma das apontadas pelo Fuzzy Delphi, esse fato reforça a 
percepção dos especialistas com a dificuldade em se prever a demanda no ambiente atual.

Outra motivação que pode-se destacar foi a "visão sistêmica" Um dos especialistas descreveu em sua resposta que a empresa buscava um sistema que conectasse toda a cadeia de suprimentos, não a enxergando apenas como silos, assim, evitando busca por eficiências locais e sim guiando a organização por um método de reabastecimento que segue a demanda real.

Outro destaque foi uma resposta que a empresa desejava uma redefinição da forma de pensar e das regras operacionais. Segundo o especialista, isso não estava claro com o MRP, os colaboradores não entendiam o que estavam fazendo e a empresa avaliou que seria uma boa oportunidade recomeçar com o DDMRP. Essa resposta expressa a percepção que o DDMRP promove maior visibilidade do todo, permitindo aos participantes da operação visualizar os processos holisticamente.

Esse entendimento também foi destacado em outra resposta, em que outro especialista avaliou como principal motivação o fato de o DDMRP permitir a comunicação entre os diferentes elos da cadeia por visualização de prioridades, direcionando os esforços para objetivos que tragam benefícios globais e não locais.

A motivação de implantação para redução da distribuição bimodal de inventário é descrita por Ptak e Smith (2016) como uma tendência de os níveis de inventário se concentrarem nos extremos, poucas quantidades ou excesso de produtos. Isso foi percebido por oitenta e oito porcento das empresas em uma pesquisa pelos autores em uma amostra de quinhentas companhias. Esse fato pode ser relacionado com outra motivação indicada pelo mesmo especialista a redução do efeito chicote, que é a propagação da distorção da percepção de pedidos ao longo da cadeia, resultando em falta de estoques ou excesso.

A última motivação destacável é apoiar estratégia omnichannel na gestão de estoques. Essa estratégia tem ganho muito destaque atualmente com a integração de diferentes canais de venda, e permite uma gestão integrada dos estoques. 


\subsubsection{Análise das barreiras}

A respeito das barreiras, é importante entender porque não houve consenso entre os especialistas de quais barreiras seriam as mais relevantes e assim, merecem mais atenção das empresas que pretendem implementar o DDMRP. Porém, primeiro é importante destacar que houve um consenso que o "B23 - Custo elevado" não se configura como uma barreira, o que pode ser entendido que o DDMRP não é uma solução de alto custo, principalmente quando comparado a sistemas similares.

Além disso, o DDMRP é disponibilizado como um módulo para os sistemas ERP de várias fornecedoras que as empresas dos respondentes já utilizavam como sistema de gestão integrado, diminuindo assim o custo de aquisição de infraestrutura de hardware e software para as empresas que já utilizam o ERP. Existe também a possibilidade de escolher entre um universo grande de fornecedores, alinhando o custo a realidade de empresa, o que pode de alguma forma explicar essa percepção de que o custo possa não ser tão alto para as empresas adotarem o DDMRP.

Com relação ao não alcance de consenso para as demais barreiras analisadas pelos especialistas, observa-se que $76 \%$ dos valores crisp estão entre 0,5 a 0,75, como destacado pela Figura 4.1, faixa essa compreendida pelos termos linguísticos moderadamente importante e importante.

Figura 4.1 - Faixa de distribuição dos valores crisp calculados - barreiras.

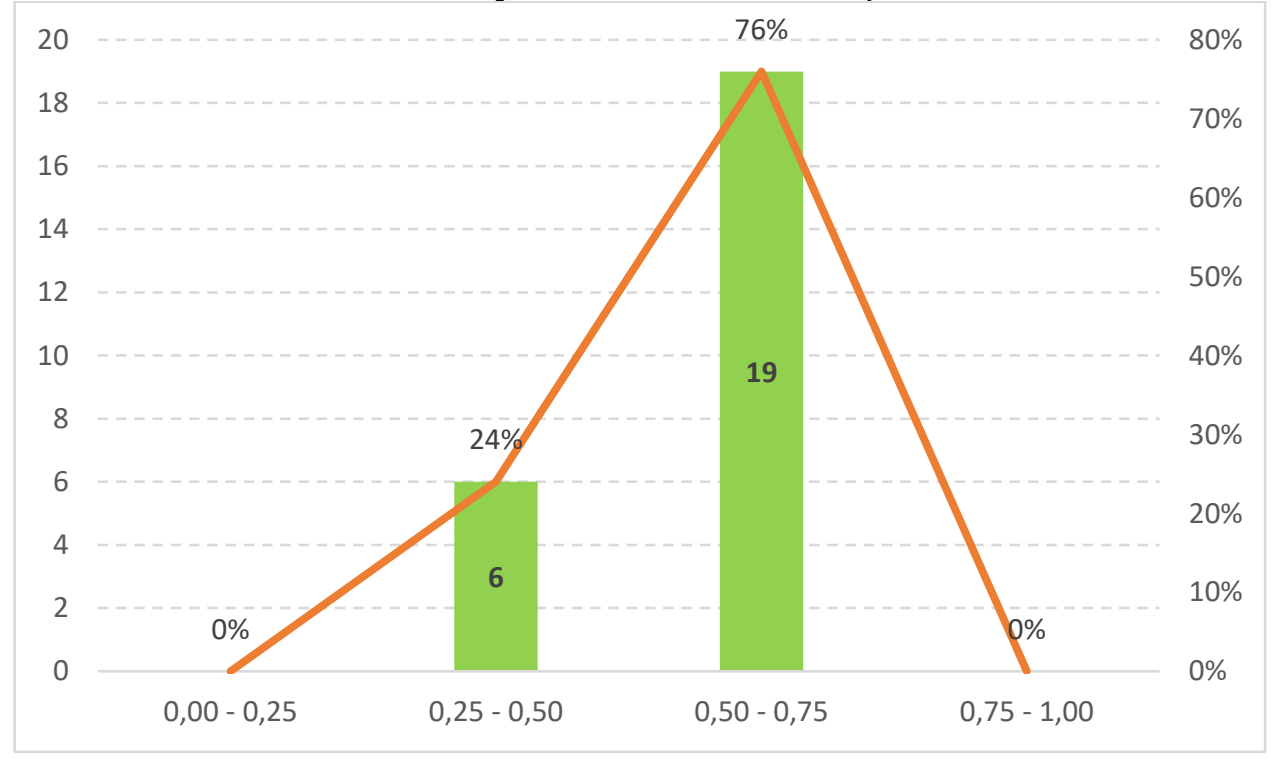

Fonte: Proposto pelo autor. 
Já a faixa de distribuição do índice de consenso com maior concentração é entre 0,25 a 0,5, como ilustrado pelo Figura 4.2.

Figura 4.2 - Faixa de distribuição do índice de consenso - barreiras.

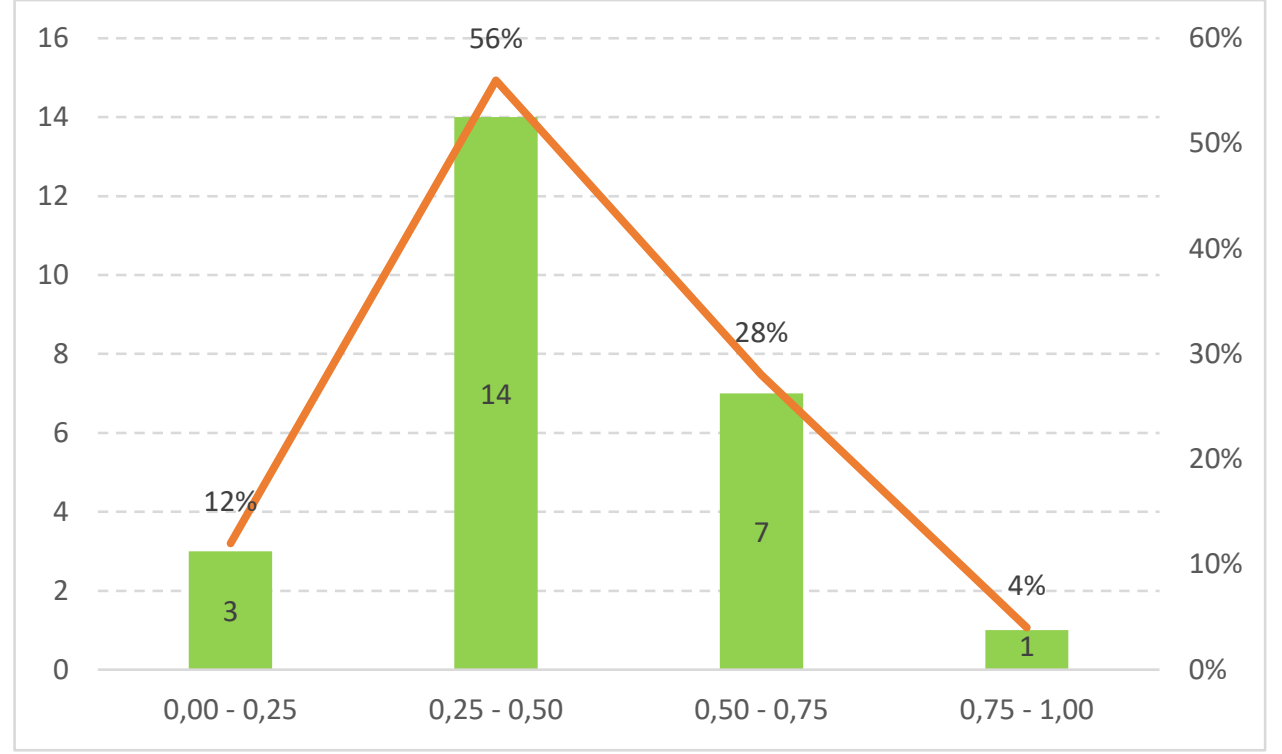

Fonte: Proposto pelo autor.

Esses dados indicam que, apesar dos valores crisp estarem próximos do limite de aceitação de 0,7, com três superando esse limite, não houve consenso entre os especialistas, ou seja, houve uma grande dispersão nas respostas dadas. Isso implica que a experiência dos especialistas na implantação do método foi bem variada. Dessa forma, entende-se que as empresas experimentam barreiras diferentes entre elas, dependendo de outros elementos influentes, como por exemplo a estrutura e a cultura organizacional.

Esse entendimento é reforçado pelas respostas das questões abertas. Dez especialistas responderam à questão aberta sobre barreiras de implementação. Além das respostas parametrizadas reportadas na seção 4.4.2, destaca-se três comentários adicionais que os especialistas fizeram em suas respostas. O primeiro destacou que a barreira mais significante encontrada foi a mudança cultural das pessoas; segundo ele "foi muito difícil fazer as pessoas mudarem a forma de trabalhar, para isso é fundamental o comprometimento da alta gerência". 
Uma outra resposta destacou o conflito quando se colocou a demanda como fator decisor de produção, distribuição e nível de inventário. O especialista destacou que para superar essa barreira é fundamental adotar novas métricas de desempenho, com novos KPI's para evitar o conflito entre os diferentes elos da cadeia interna da empresa.

O último comentário destaca que uma barreira relevante foi a falta de vontade das pessoas em tentar e buscar uma solução nova, elas se sentem confortáveis com o MRP, que as deixa ocupadas resolvendo problemas o tempo todo, como "bombeiros" nas palavras de um dos especialistas.

Destaca-se ainda uma resposta das questões abertas, que indica que as barreiras culturais são mais relevantes que as técnicas, apesar dos autores Velasco Acosta, Mascle e Baptiste (2019) destacarem que muitos aspectos do DDMRP são subjetivos e dependem de julgamentos dos planejadores, como por exemplo, posicionamento dos buffers, nível dos buffers, frequência dos ajustes dinâmicos dos buffers e fator de lead time e variabilidade.

Assim, pode entender que os especialistas não tiveram dificuldade em determinar esses fatores técnicos que dependem de julgamentos subjetivos e experiência com o DDMRP ou o sistema de produção da empresa. Diante desses resultados é difícil concluir que nenhuma barreira é relevante, mas sim que elas são subjetivas a cada empresa e gestor, apenas as seis barreiras que tiveram valores crisp abaixo de 0,5 pode-se entender que realmente não são recorrentes.

\subsubsection{Análise dos fatores críticos de sucesso}

Com os fatores críticos de sucesso ocorreu o inverso das barreiras, houve um alto nível de consenso entre os especialistas. As Figuras 4.3 e 4.4 apresentam as faixas de distribuição dos valores crisp e do índice de consenso para os fatores analisados. 
Figura 4.3 - Faixa de distribuição dos valores crisp calculados - fatores críticos de sucesso.

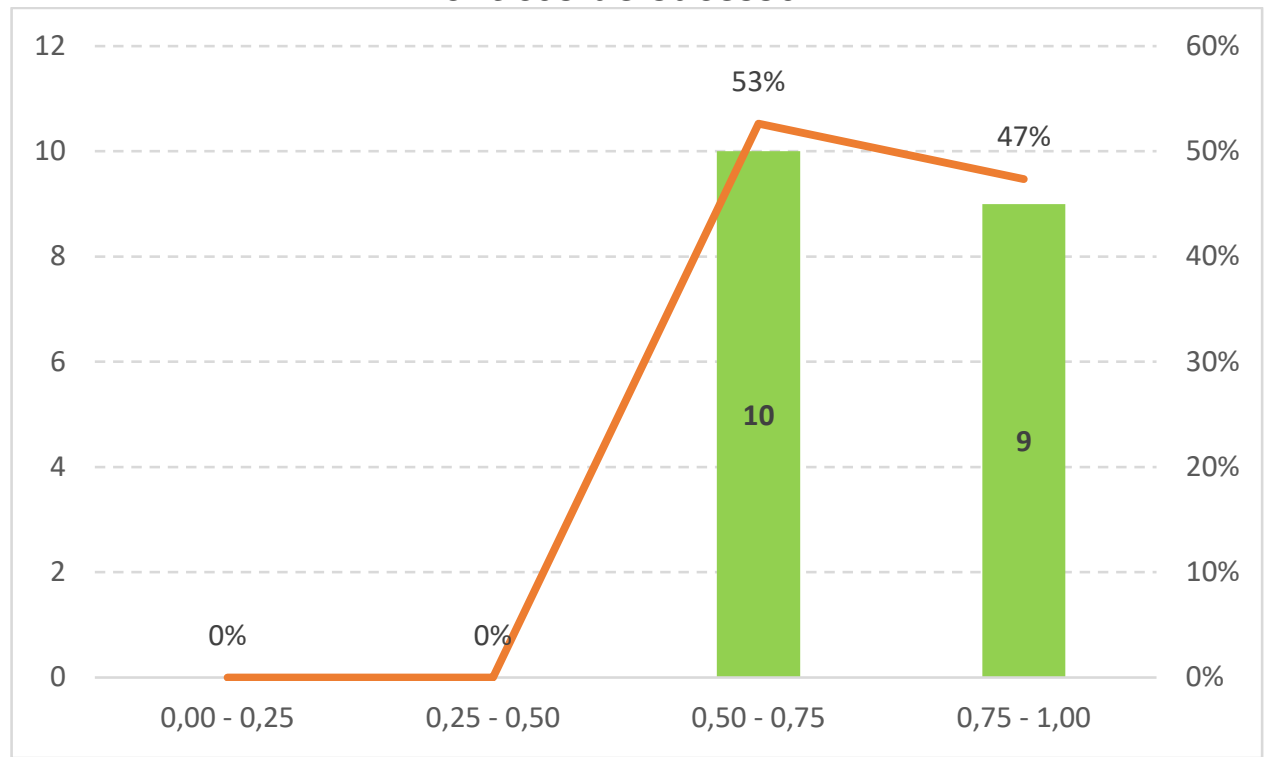

Fonte: Proposto pelo autor.

Figura 4.4 - Faixa de distribuição do índice de consenso - fatores críticos de sucesso.

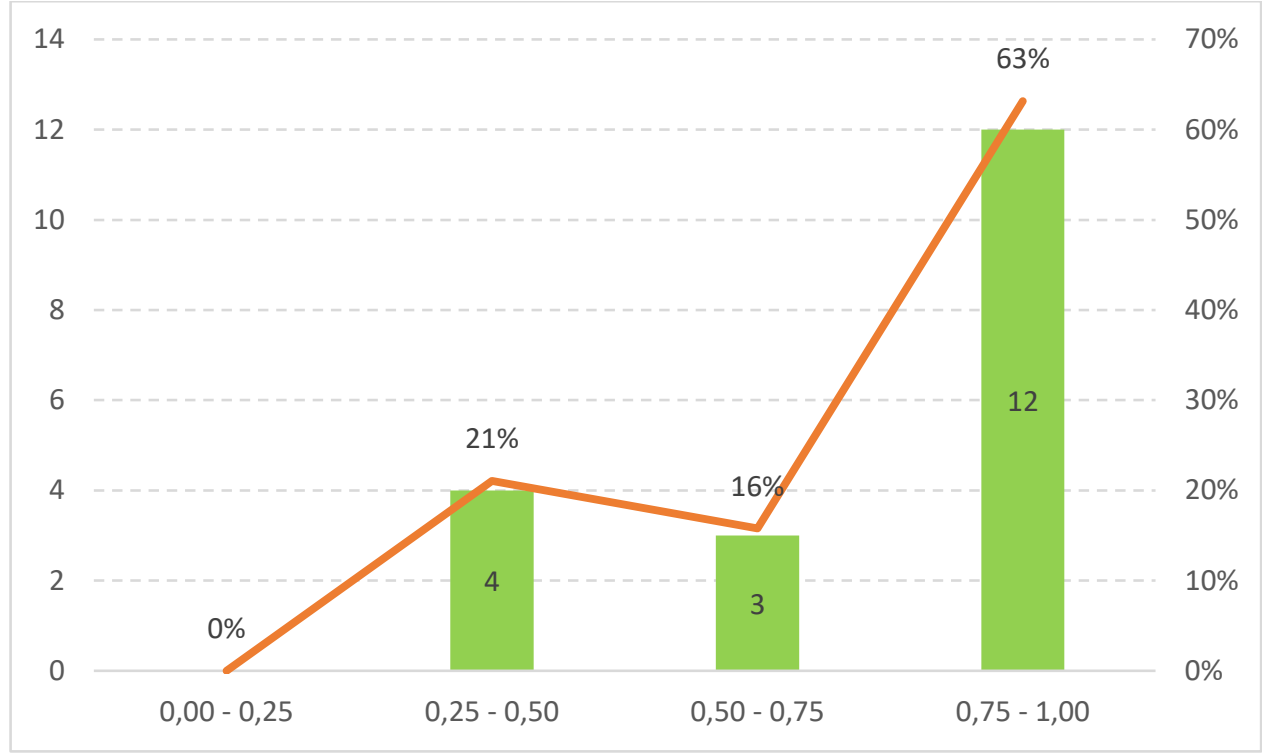

Fonte: Proposto pelo autor.

Isso pode ser explicado pois muitos dos fatores analisados serem recorrentes na implementação de outros sistemas de gestão da produção, como visto no Capítulo 2. Além disso, muitos deles são fatores de decisões gerenciais ou fatores culturais e também complementares às barreiras. Dessa forma, era esperado que muitos deles fossem importantes para a 
implementação do DDMRP, que é um sistema de planejamento e controle de produção.

Dos fatores aceitos através da metodologia Fuzzy Delphi proposta, pode-se destacar o suporte de consultores externos, uma vez que pôr o DDMRP ser um método ainda pouco difundido uma das formas de introduzilo na organização seja por meio de consultorias profissionais especializadas.

Dos fatores que não alcançaram os critérios mínimos estabelecidos para o Fuzzy Delphi é importante destacar que cinco alcançaram o valor crisp mínimo exigido de 0,7, porém não alcançaram consenso ("FC12 - Adequação do DDMRP ao tipo de resposta à demanda da empresa", "FC6 - Suporte do fornecedor do sistema", "FC7 - Disponibilidade de recursos", "FC17 Compartilhamento de informações", "FC18 - Cultura organizacional proativa"). Dessa forma, pode-se afirmar que são fatores que provocaram julgamentos mistos.

Houve ainda três fatores com um consenso de que não seriam muito importantes ("FC11 - Adequação do DDMRP à filosofia da empresa", "FC4 Planejamento de longo prazo" e "FC19 - Experiência dos colaboradores com a empresa"). A respeito do fator FC11 pode-se inferir que o DDMRP é um método flexível, aplicável a muitas filosofias empresariais.

A "experiência dos colaboradores com a empresa" foi entendida como moderadamente importante, apesar de o DDMRP possuir fatores subjetivos, como destacado por Velasco Acosta, Mascle e Baptiste (2019). Entende-se que isso possa ser compensado pelo conhecimento aprofundado do método e por suporte de consultores externos.

Com relação ao fator "FC4 - Planejamento de longo prazo", pode-se entender que a implementação não tem um prazo muito longo, por isso foi um fator avaliado como mediamente importante, não passando pelos critérios estabelecidos previamente pela metodologia. Porém, o planejamento de longo prazo é descrito na bibliografia de implementação de sistemas de PCP como importante, como por exemplo por Abu et al. (2019), que em sua revisão bibliográfica apontou a orientação a longo prazo como importante para a implementação do Lean.

Além disso, nas respostas abertas um dos especialistas reportou que o pós-implementação deve ser considerado como um fator crítico de sucesso, ou seja, acompanhamento para evolução do uso do sistema, evitando 
retroações a práticas antigas. Essa colocação reforça o entendimento de planejamento de longo prazo, por isso é imprudente afirmar que o planejamento de longo prazo não é importante, apesar de que pela metodologia Fuzzy Delphi esse fator não alcançou os limites estabelecidos, ficando próximo com valor crisp de 0,674.

Outras duas respostas abertas que são importantes de destacar são as duas que indicam a importância da adoção de novas métricas de desempenho, novos KPI's. Um dos especialistas afirmou que o DDMRP foca o fluxo de produção, e a teoria das restrições reportou um conflito de ações que promovem o fluxo com os indicadores de desempenho da contabilidade de custos. Dessa forma, é muito importante incluir o setor financeiro no treinamento, mudar a lógica de medição, trocando o foco das eficiências locais para as globais, criando uma visão holística da companhia. 


\section{CAPÍTULO 5 - CONCLUSÃO}

\subsection{CONTRIBUIÇÕES DA PESQUISA}

O objetivo desse estudo foi identificar motivos, barreiras e fatores críticos de sucesso para a implementação do DDMRP em cadeias de suprimentos. Para isso, buscou-se consolidar uma coletânea de estudo que pudessem direcionar a pesquisa, uma vez que nenhum trabalho com viés quantitativo foi realizado até então, apenas dois trabalhos sobre primeiros elementos empíricos de motivações (BAHU; BIRONNEAU; HOVELAQUE, 2019; MCCULLEN; EAGLE, 2015).

Assim, com a exploração do tema das cadeias ágeis e demand driven, implementação de sistemas de PCP e limitações dos métodos atuais em ambientes de difícil previsão pode-se extrair constructos para o questionário Fuzzy Delphi. Também, foi realizada uma descrição do DDMRP, procurando levantar elementos técnicos para o questionário e uma revisão da bibliografia acadêmico-científica de trabalhos publicados sobre esse método.

Dessa forma, a primeira contribuição do trabalho é expandir as áreas de estudo do DDMRP; a maioria dos estudos até então foram sobre simulações do método em ambientes de manufatura e alguns poucos estudos de caso. Além disso, esse é um dos poucos trabalhos a explorar o DDMRP no universo acadêmico brasileiro, servindo como ponto de partida para maior exploração do tema no universo acadêmico do país.

Adicionalmente, o trabalho contribui na identificação das motivações mais importantes para implementação do DDMRP, na visão de especialistas que atuam na área, as barreiras mais relevantes, apesar do não consenso ainda é possível ranquear as barreiras e considera-las como ponto de atenção na implementação, bem como as barreiras apontadas pelas questões abertas. Também, foram identificados os fatores críticos de sucesso mais importantes, com a adição de fatores relatados nas questões abertas.

Por fim, pode-se considerar a contribuição que o trabalho dá em reunir as principais publicações sobre o DDMRP, com 15 trabalhos reunidos sobre o tema. 
Dessa forma, entende-se que essas contribuições podem ajudar a embasar decisões gerenciais para implementação do DDMRP, bem como ser referência para novos trabalhos envolvendo o tema, assim, espera-se que esse trabalho possa contribuir para o entendimento do DDMRP no universo acadêmico-científico e estimular novas pesquisas sobre esse tema ainda pouco explorado na literatura. Evidencia-se, assim, o atendimento pleno aos objetivos traçados para essa dissertação de mestrado.

Ademais, destaca-se o papel que este trabalho pode ter no ambiente empresarial e as contribuições para seus profissionais. Os resultados evidenciam, com base em uma amostra de especialistas sobre o tema e suas experiências na implementação do DDMRP e com método de pesquisa consolidado as principais motivações, barreiras e fatores críticos de sucesso com a visão de pares que já participaram ou estudaram o tema em diferentes contextos, com diferentes experiências e diferentes países. Os resultados constituem-se, assim, em uma fonte de informações muito contributivas àqueles que podem comparar suas próprias experiências aos resultados alcançados e, também, servir de base para aqueles que desejam ou planejam encaminhar a adoção do DDMRP em suas operações.

\subsection{PESQUISAS FUTURAS E LIMITAÇÕES DA PESQUISA}

Apesar de ter alcançado contribuições, o estudo apresenta algumas limitações que podem ser exploradas em trabalhos futuros complementares. Pode-se considerar a revisão da literatura como uma limitação, o estudo realizou um levantamento de fatores de implementação de cadeias ágeis e demand driven a partir de estudos identificados, porém estudos não contemplados que deverão ser publicados futuramente podem apresentar outros elementos a serem analisados.

Além disso, apesar de as bases de dados escolhidas serem as principais para pesquisas acadêmicas (BUCHINGER; CAVALCANTI; HOUNSELL, 2014) artigos não publicados nesses locais não foram retornados, como publicações de eventos como congressos e simpósios. Também, podem ter ocorrido 
limitações de acesso por questões de idiomas, como o artigo adicionado posterior por indicação durante a pesquisa de campo.

Outra sugestão para trabalhos futuros é usar métodos de tomada de decisão com comparação par-a-par para as barreiras que não alcançaram consenso pelo método Fuzzy Delphi. Uma possibilidade é o método Fuzzy AHP que também utiliza a lógica fuzzy para lidar com incertezas de julgamentos e realiza essa comparação, assim, permitindo uma ordenação das mais relevantes. 


\section{REFERÊNCIAS}

$A B U, F$. et al. The implementation of lean manufacturing in the furniture industry: A review and analysis on the motives, barriers, challenges, and the applications. Journal of Cleaner Production, v. 234, p. 660-680, 2019.

AGARWAL, A.; SHANKAR, R.; TIWARI, M. K. Modeling the metrics of lean, agile and leagile supply chain: an ANP-based approach. European Journal of Operational Research v. 173 (1), 211-225, 2006.

AITKEN, J.; CHRISTOPHER, M.; TOWILL, D. Understanding, implementing and exploiting agility and leanness. International Journal of Logistics: Research and Applications v. 5 (1), 59-74, 2002.

AL-MUDIMIGH， A.; ZAIRI, M.; AL-MASHARI, M. ERP software implementation: An integrative framework. European Journal of Information Systems, v. 10, n. 4, p. 216-226, 2001.

ANG, J. S. K.; SUM, C. C.; CHUNG, W. F. Critical success factors in implementing MRP and government assistance: A Singapore context. Information and Management, v. 29, n. 2, p. 63-70, 1995.

ANG, J. S. K.; SUM, C. C.; YANG, K. K. MRP II company profile and implementation problems: A Singapore experience. International Journal of Production Economics, v. 34, n. 1, p. 35-45, 1994.

ANG, J. S. K.; SUM, C. C.; YEO, L. N. A multiple-case design methodology for studying MRP success and CSFs. Information and Management, v. 39, n. 4, p. 271-281, 2002.

AYERS, J.; MALMBERG, D. Supply chains systems: are you ready? Information Strategy: The Executive's Journal, 2002.

BABAEI, M.; GHOLAMI, Z.; ALTAFI, S. Challenges of Enterprise Resource Planning implementation in Iran large organizations. Information Systems, v. 54 , p. $15-27,2015$.

BAHU, B.; BIRONNEAU, L.; HOVELAQUE, V. Compréhension du DDMRP et de son adoption : premiers éléments empiriques. Logistique \& Management, v. 27 , n. 1, p. 20-32, 2019. 
BINGI, P.; SHARMA, M. K.; GODLA, J. K. Critical issues affecting an ERP implementation. Information Systems Management, v. 16, n. 3, p. 7-14, 1999.

BIRHANU, D.; LANKA, K.; RAO, A. N. A survey of classifications in supply chain strategies. Procedia Engineering, n. 97, p. 2289 - 2297, 2014.

BLACKBURN, R. et al. A predictive analytics approach for demand forecasting in the process industry. International Transactions in Operational Research, v. 22, n. 3, p. 407-428, 2015.

BOGNER, A.; LITTING, B.; MENZ, W. Interviewing Experts. Palgrave Macmillan, 2009

BOUZON, M. et al. Identification and analysis of reverse logistics barriers using fuzzy Delphi method and AHP. Resources, Conservation and Recycling, v. 108, p. 182-197, 2016.

BOWERSOX, D. C.; CLOSS, D.; COOPER, M. B. Supply Chain Logistics Management. Irwin: McGraw-Hill, fourth edition, 2012.

BOYD, J. R.; WETFALL, H. Pesquisa mercadológica: textos e casos. Rio de Janeiro: Fundação Getulio Vargas, 1964.

BRÁS, J.; MARQUES, V. Método DELPHI : caracterização e potencialidades na pesquisa em educação. Pro-Posições v. 29, n. 2 (87), p. 389-415, 2018.

BRAUNSCHEIDEL, M. J.; SURESH, N. C. The organizational antecedents of a firm's supply chain agility for risk mitigation and response. Journal of Operations Management v. 27 (2), 119-140, 2009.

BRYMAN, A. Research methods and organizations studies. London: Unwin Hyman, 1989.

BRYMAN, A. Integrating quantitative and qualitative research: how is it done? Qualitative Research, v. 6, n.1, p. 97-113, 2006.

BUCHINGER, D. ; DE SIQUEIRA CAVALCANTI, G. A.; DA SILVA HOUNSELL, M. Mecanismos de busca acadêmica: uma análise quantitativa. Revista Brasileira de Computação Aplicada, v. 6, n. 1, p. 108-120, 2014.

BUDD, J.; KNIZEK, C.; TEVELSON, B. The demand-driven supply chain, making it work and delivering results, Boston Consulting Group, 2012. 
BUENO, S.; SALMERON, J. L. Fuzzy modeling enterprise resource planning tool selection. Computer Standards \& Interfaces, v. 30 (3), 137-147, 2008.

BUI, T. D. et al. Identifying sustainable solid waste management barriers in practice using the fuzzy Delphi method. Resources, Conservation and Recycling, v. 154, n. August 2019, p. 104625, 2020.

BURGESS, T. Making the leap to agility: defining and achieving agile manufacturing through business process redesign and business network redesign. International Journal of Operations and Production Management, Vol. 14 (11),23-34, 1994.

CERVO, A. L.; BERVIAN, P. A. Metodologia científica. 4a Ed. São Paulo: Makron Books, 1996.

CHANG, T. H. et al. Measuring the success possibility of implementing ERP by utilizing the incomplete linguistic preference relations. Applied Soft Computing Journal, v. 12, n. 5, p. 1582-1591, 2012.

CHOPRA, S.; MEINDL, P. Supply Chain Management: Strategy, Planning, and Operation. Third edition, Pearson, New Jersey, 2007.

CHRISTOPHER, M.; HOLWEG, M. "Supply Chain 2.0": Managing supply chains in the era of turbulence. International Journal of Physical Distribution and Logistics Management, v. 41, n. 1, p. 63-82, 2011.

CHRISTOPHER, M. The agile supply chain: competing in volatile markets. Industrial Marketing Management, v. 29 (1), p. 37-44, 2000.

CHRISTOPHER, M. Logistics and Supply Chain Management: Creating Valueadded Networks. FT Prentice Hall, Harlow, 2005.

COHEN, N.; ARIELI, T. Field research in conflict environments: Methodological challenges and snowball sampling. Journal of Peace Research, v. 48, n. 4, p. 423-435, 2011.

COHEN, S; ROUSSEL, J. Strategic Supply Chain Management: The Five Disciplines for Top Performance, Second Edition. McGraw-Hill Professional, 2013. 
COLLINS, J; HUSSEY, R. Pesquisa em Administração: um guia prático para alunos de graduação e pós-graduação. Tradução: Lucia Simonini. 2. Ed. Porto Alegre: Bookman, 2005.

CORRÊA, H. L. ; GIANESI, I. G. N. ; CAON, M. Planejamento, Programação e Controle da produção. 4a Ed. Editora Atlas, São Paulo, 2001.

CORRÊA, H. L.; GiAnesi, I. G. N. Just in Time, MRP II e OPT - Um enfoque estratégico. Editora Atlas, 2. ed., 1996.

DALKEY, N.; HELMER, O. An Experimental Application of the Delphi Method to the Use of Experts Management Science, 1963.

DAVIS, T. Effective supply chain management, MIT Sloan Management Review, 35-46, 1993.

DISNEY, S. M. et al. Inventory management for stochastic lead times with order crossovers. European Journal of Operational Research, v. 248, n. 2, p. 473-486, 2016.

DONG, J.; HUO, H. Identification of financing barriers to energy efficiency in small and medium-sized enterprises by integrating the fuzzy delphi and fuzzy DEMATEL Approaches. Energies, v. 10, n. 8, 2017.

DUCHESSI, P.; SCHANINGER, C. M.; HOBBS, D. R. Implementing a manufacturing planning and control information system. California Management Review, 31, 3, 1989.

DUCROT, L.; AHMED, E. Investigation of potential added value of DDMRP in planning under uncertainty at finite capacity. [s.l.] MASSACHUSETTS INSTITUTE OF TECHNOLOGY, 2019.

DURMUŞOĞLU, S.; SÜMEN, H.; YENEN, V. Z. The state-of-the-art of MRP/MRP II implementation in Turkey. Production Planning and Control, v. 7, n. 1, p. 2-10, 1996.

ERKAYMAN, B. Transition to a JIT production system through ERP implementation: a case from the automotive industry. International Journal of Production Research, v. 7543, 2018.

FISHER, M. What is the right Supply Chain for your product? Harvard Business Review, March-April, 1997. 
FLEURY, A. Planejamento do Projeto de Pesquisa e Definição do Modelo Teórico. Em: MIGUEL, P. A. C. (Ed.). Metodologia de Pesquisa em Engenharia de Produção e Gestão de Operações. $2^{a}$ edição. Rio de Janeiro: Elsevier/ABEPRO, 2012 p. 33.

FORZA, C. Survey research in operations management: a process-based perspective. International Journal of Operations \& Production Management, v. 22, n. 2, p. 152-194, 2002.

FRISCIA, T.; O'MARAH, K.; HOFMAN, D. ; SOUZA, J. The AMR Research Supply Chain Top 25 for 2009. AMR Research, Boston, MA, USA, 2009.

GALO, N. R. Proposta de modelo de decisão para avaliação de fornecedores baseado no ELECTRE TRI para categorização e na teoria dos conjuntos fuzzy para a modelagem da incerteza e hesitação de múltiplos tomadores de decisão. Tese (Doutorado). Escola de Engenharia de São Carlos - Universidade de São Paulo, 2018.

GANJI, E. N.; SHAH, S.; COUTROUBIS, A. An examination of product development approaches within demand driven chains, Asia Pacific Journal of Marketing and Logistics, v. 30 Issue: 5, pp. 1183-1199, 2018.

GATTORNA, J. Living supply chains: alinhamento dinâmico de cadeias de valor. São Paulo: Person Prentice Hall, 2009.

GE, L.; VOSS, S. ERP application in China: An overview. International Journal of Production Economics, v. 122, n. 1, p. 501-507, 2009.

GOLDMAN, S. L.; NAGEL, R. N.; PREISS, K. Agile Competitors and Virtual Organizations: Strategies for Enriching the Customer. Van Nostrand Reinhold, New York, 1995.

GOLLAMUDI, R. Demand Driven S\&OP - Maximizing Output to Match Demand Variation. BristleCone: Your Supply Chain Optimized, v. 22, 2013.

GOSLING, J.; PURVIS, L.; NAIM, M. M. Supply chain flexibility as a determinant of supplier selection. International Journal of Production Economics v. 128 (1), 11-21, 2010.

GOVINDAN, K.; SOLEIMANI, H.; KANNAN, D. Reverse logistics and closedloop supply chain: A comprehensive review to explore the future. European Journal of Operational Research, v. 240, n. 3, p. 603-626, fev. 2015. 
GUANG-HUI, C.; CHUN-QING, L.; YUN-XIU, S. Critical success factors for ERP life cycle implementation. IFIP International Federation for Information Processing, v. 205, p. 553-562, 2006.

HABIBI, A.; JAHANTIGH, F. F.; SARAFRAZI, A. Fuzzy Delphi Technique for Forecasting and Screening Items. Asian Journal of Research in Business Economics and Management, v. 5, n. 2, p. 130, 2015.

HADAYA, P.; CASSIVI, L. The Role of Joint Collaboration Planning Actions in a Demand-driven Supply Chain. Industrial Management \& Data Systems, v. 107 (7), 954-978, 2007.

HARLAND, C. M. Supply chain management: relationships, chains and networks. British Journal of Management v. 7 (S1), S63-S80, 1996.

HARRISON, T. P.; LEE, H. L.; NEALE, J. J. The Practice of Supply Chain Management, John Wiley \& Sons, New York, 2003.

HENKEL, K. A categorização e a validação das respostas abertas em surveys políticos. Opinião Pública, v. 23, n. 3, p. 786-808, 2017.

$\mathrm{HO}, \mathrm{C} . ; \mathrm{HO}, \mathrm{S} . \mathrm{J} . \mathrm{K}$. Evaluating the effectiveness of using lot-sizing rules to cope with MRP system nervousness. Production Planning and Control, v. 10, n. 2, p. 150-161, 1999.

HSU, Y. L.; LEE, C. H.; KRENG, V. B. The application of Fuzzy Delphi Method and Fuzzy AHP in lubricant regenerative technology selection. Expert Systems with Applications, v. 37, n. 1, p. 419-425, 2010.

IHME, M.; STRATTON, R. Evaluating Demand Driven MRP: a case based simulated study. In: International Conference of the European Operations Management Association. Anais, 2015. Disponível em: <http://irep.ntu.ac.uk/id/eprint/26668/>.

ISHIKAWA, A. et al. The man-min Delphi method and fuzzy Delphi method via fuzzy integration. Fuzzy Sets and Systems, v. 55, n. 3, p. 241-253, 1993.

JADHAV, J. R.; MANTHA, S. S.; RANE, S. B. Exploring barriers in lean implementation. International Journal of Lean Six Sigma, v. 5, n. 2, p. $122-148,2014$. 
JAIN, V.; BENYOUCEF, L.; DESHMUKH, S. G. A new approach for evaluating agility in supply chains using fuzzy association rules mining. Engineering Applications of Artificial Intelligence v. 21(3), 367-385, 2008.

JUPP, V. The Sage dictionary of social research methods. London: Sage Publications, 2006.

KARSAK, E. E.; ÖZOGUL, C. O. An integrated decision making approach for ERP system selection. Expert Systems with Applications, v. 36, p. 660$667,2009$.

KAUFMANN, A. ; GUPTA, M. M. Fuzzy Mathematical Models in Engineering and Management Science. New York: Elsevier Science Inc., 1988.

KIDD, P. T. Agile Manufacturing: Forging New Frontiers. Addison-Wesley, Wokingham, England, 1994.

KILIC, H. S. ; ZAIM, S.; DELEN, D. Selecting "the best" ERP system for SMEs using a combination of ANP and PROMETHEE methods. Expert Systems with Applications, v. 42 (5), p. 2343-2352, 2015.

KISPERSKA-MORON, D.; DE HAAN, J. Improving supply chain performance to satisfy final customers: leagile experiences of a Polish distributor. International Journal of Production Economics v. 133(1), 127-134, 2011.

$\mathrm{KOH}, \mathrm{S}$. C. et al. Measuring uncertainties in MRP environments. Journal of Logistics Information Management, v. 13, 177-183, 2000.

KOH, S. C. L.; GUNASEKARAN, A.; GOODMAN, T. Drivers, barriers and critical success factors for ERPII implementation in supply chains: A critical analysis. Journal of Strategic Information Systems, v. 20, n. 4, p. 385-402, 2011. $\mathrm{KOH}$ S. C. L.; SAAD S. M.; JONES M. H. Uncertainty under MRP planned manufacture: Review and categorization, International Journal of Production Research, v. 40:10, 2399-2421, 2002.

KORTABARRIA, A. et al. Material management without forecasting: From MRP to demand driven MRP. Journal of Industrial Engineering and Management, v. 11, n. 4, p. 632, 2018. 
KUMAR, V.; MAHESHWARI, B.; KUMAR, U. Enterprise resource planning systems adoption process: A survey of Canadian organizations. International Journal of Production Research, v. 40, n. 3, p. 509-523, 2002.

KUO, Y. F.; CHEN, P. C. Constructing performance appraisal indicators for mobility of the service industries using Fuzzy Delphi Method. Expert Systems with Applications, v. 35, n. 4, p. 1930-1939, 2008.

LAMBERT, D. M.; COOPER, M. C.; PAGH, J. D. Supply Chain Management: Implementation Issues and Research Opportunities. The International Journal of Logistics Management, v. 9 Iss 2 pp. 1 - 20, 1998.

LAMMING, R.; JOHNSEN, T.; ZHENG, J.; HARLAND, C. An initial classification of supply networks, International Journal of Operations \& Production Management, v. 20 (6), p. 675 - 691, 2000.

LEE, C. J.; RIM, S. C. A Mathematical Safety Stock Model for DDMRP Inventory Replenishment. Mathematical Problems in Engineering, $v$. 2019, 2019.

LEE, H. L. Aligning supply chain strategies with product uncertainties, California Management Review, v. 44, 105-120, (2002).

LIN, C. T.; CHIU, H.; CHU, P. Y. Agility index in the supply chain. International Journal of Production Economics, v. 100, n. 2, p. 285$299,2006$.

LIU, H. T.; WANG, W. K. An integrated fuzzy approach for provider evaluation and selection in third-party logistics. Expert Systems with Applications, v. 36, n. 3 PART 1, p. 4387-4398, 2009.

MA, Z.; SHAO, C.; MA, S.; YE, Z. Constructing road safety performance indicators using fuzzy delphi method and grey delphi method. Expert Systems with Applications, v. 38 (3), 1509-1514, 2011.

MABERT, V.; SONI, A.; VENKATARAMANAN, M. Enterprise resource planning: Managing the. European Journal of Operational Research, v. 146, n. SUPPL, p. 302-314, 2003. 
MADITINOS, D.; CHATZOUDES, D.; TSAIRIDIS, C. Factors affecting ERP system implementation effectiveness. Journal of Enterprise Information Management, v. 25, n. 1, p. 60-78, 2011.

MANAKANDAN, S. K. et al. Pesticide applicators questionnaire content validation: A fuzzy delphi method. Medical Journal of Malaysia, v. 72, $n$. 4, p. 228-235, 2017.

MASON-JONES, R.; NAYLOR, B.; TOWILL, D. R. Lean, agile or leagile? Matching your supply chain to the marketplace, International Journal of Production Research, v. 38 (17), 4061-4070, 2000.

MASON-JONES, R.; TOWILL, D. R. Information enrichment: designing the supply chain for competitive advantage. Supply Chain Management v. 2 (4), 137-148, 1997.

MASON-JONES, R.; TOWILL, D. T. Total cycle time compression and the agile supply chain. International Journal of Production Economics v.62 (1/2), 61-73, 1999.

MATTAR, F. N. Pesquisa de marketing: metodologia, plananejamento. São Paulo: Atlas, 1996.

MAYRING, P. Qualitative Inhaltsanalyse. Berlin, Springer, 2010.

MCCULLEN, P.; EAGLE, S. Demand-driven innovation in materials planning and control: a review of early implementations. In: The Proceedings of 20th International Symposium on Logistics, July 5-8, Bologna, Anais, pp. 85-92, 2015.

MENDES, P.; LEAL, J. E.; THOMÉ, A. M. T. A maturity model for demanddriven supply chains in the consumer product goods industry. International Journal of Production Economics, v. 179, 153-165, 2016.

MICHAEL, R. K.; WEMPE, W.F. Further evidence on the extent and origins of JIT's profitability effects. Accounting Review v. 77 (1), 203-225, 2002.

MICLO, R. Challenging the "Demand Driven MRP" Promises': A Discrete Event Simulation Approach. PhD thesis, Ecole Des Mines D'Albi-Carmaux, 2016. MICLO, R. et al. An empirical comparison of MRPII and Demand-Driven MRP. IFAC-PapersOnLine. Anais. Elsevier B.V., pp. 1725-1730, 2016a. Disponível 
em: <http://dx.doi.org/10.1016/j.ifacol.2016.07.831>

MICLO, R. et al. MRP vs. Demand-driven MRP: Towards an objective comparison. In: Proceedings of 2015 International Conference on Industrial Engineering and Systems Management, IEEE IESM 2015. October 21-23, Seville, Anais. International Institute for Innovation, Industrial Engineering and Entrepreneurship - I4e2, 2016b.

MICLO, R. et al. Demand Driven MRP: assessment of a new approach to materials management. International Journal of Production Research, v. 57, n. 1, p. 166-181, 2019.

MIGUEL, P. A. C. Estudo de caso na engenharia de produção: estruturação e recomendações para sua condução. Produção. v. 17, n.1, 2007.

MIGUEL, P. A. C.; HO, L. L. Levantamento Tipo Survey. Em: MIGUEL, P. A. C. (Ed.). Metodologia de Pesquisa em Engenharia de Produção e Gestão de Operações. $2^{a}$ edição. Rio de Janeiro: Elsevier/ABEPRO, 2012 p. 75.

MIKE, D.; VENU, N.; FLORIAN, W. Agile operations for volatile times. McKinsey Quarterly 3, 126-131, May, 2012.

NAIM, M. M.; GOSLING, J. On leanness, agility and leagile supply chains. International Journal of Production Economics v. 131 (1), 342-354, 2011.

NAIM, M.; NAYLOR, B.; BARLOW, J. Developing lean and agile supply chains in the UK house building industry, IGLC-7, pp. 59- 170, 1999.

OGAWA, S.; PILLER, F.T. Reducing the risks of new product development, MIT Sloan Management Review, Vol. 47 No. 2, pp. 65-71, 2006.

OLHAGER, J. Strategic positioning of the order penetration point. International Journal of Production Economics, v. 85, 319-329, 2003.

ORUE, A.; LIZARRALDE, A.; KORTABARRIA, A. Demand driven MRP - the need to standardise an implementation process. International Journal of Production Management and Engineering, v. 8, n. 2, p. 65-73, 2020. PARR, A.; SHANKS, G. A model of ERP project implementation. Journal of Information Technology, v. 15, n. 4, p. 289-303, 2000. 
PEKARCÍKOVÁ, M. et al. Demand driven material requirements planning. some methodical and practical comments. Management and Production Engineering Review, v. 10, n. 2, p. 50-59, 2019.

PETRONI, A. Critical factors of MRP implementation in small and mediumsized firms. International Journal of Operations and Production Management, v. 22, n. 3, p. 329-348, 2002.

POIGER, M. Improving performance of supply chain processes by reducing variability, PhD Dissertation, Vienna University of Economics and Business, 2010.

PRAJOGO, D. I.; SOHAL, A. S. The relationship between organization strategy, total quality management (TQM), and organization performancethe mediating role of TQM. European Journal of Operational Research $v$. 168 (1), 35-50, 2006.

PREUVENEERS, D.; ILIE-ZUDOR, E. The intelligent industry of the future: A survey on emerging trends, research challenges and opportunities in Industry 4.0. Journal of Ambient Intelligence and Smart Environments, v. 9, n. 3, p. 287-298, 2017.

PTAK, C.; SMITH, C. Orlicky's Material Requirements Planning 3/E. New York: McGraw Hill Professional, 2011.

PTAK, C.; SMITH, C. Demand Driven Material Requirements Planning (DDMRP). Norwalk, CT: Industrial Press, 2016.

ROBSON, S. Real World Research: A resource for social scientists and practitioner researcher. Blackwell Publishers, UK, 2002.

ROMANO, P. Impact of supply chain sensitivity to quality certification on quality management practices and performances. Total Quality Management v. 13 (7), 981-1000, 2000.

SALONITIS, K.; TSINOPOULOS, C. Drivers and Barriers of Lean Implementation in the Greek Manufacturing Sector. Procedia CIRP, v. 57, n. June 2017, p. 189-194, 2016.

SHOFA, M. J.; MOEIS, A. O.; RESTIANA, N. Effective production planning for purchased part under long lead time and uncertain demand: MRP Vs demanddriven MRP. In: International Conference on Industrial and System 
Engineering. IOP Conference Series: Materials Science and Engineering. Anais, 2018.

SHOFA, M. J.; WIDYARTO, W. O. Effective production control in an automotive industry: MRP vs. demand-driven MRP. IN: AIP Conference Proceedings. Anais, 2017. Disponível em: < https://doi.org/10.1063/1.4985449>.

SIMCHI-LEVI, D.; KAMINSKY, P.; SIMCHI-LEVI, E. Cadeia de suprimentos: projeto e gestão. Porto Alegre, Bookman, 2010.

STAATS, B. R.; BRUNNER, D. J.; UPTON, D. M. Upton. Lean Principles, Learning, and Knowledge Work: Evidence from a Software Services Provider. Journal of Operations Management, v.29, p. 376-390, 2011.

STALK, G. Time-the next source of competitive advantage. 1988.

STEFANO, N. M.; CASAROTTO FILHO, N.; DUARTE, M. DO C. F. Proposta De Um Instrumento De Pesquisa Para Avaliar a Gestão De Periódicos Científicos : Utilizando O Método Fuzzy Delphi. Iberoamerican Journal of Project Management, v. 5, n. 2, p. 39-69, 2014.

SURI, R. Quick response manufacturing: a companywide approach to reducing lead times. CRC Press, 1998.

SWAFFORD, P. M.; GHOSH, S.; MURTHY, N. Achieving supply chain agility through IT integration and flexibility. International Journal of Production Economics v. 116 (2), 288-297, 2008.

TINHAM, B. The MRP/ERP user satisfaction survey 1999. Manufacturing Computer Solutions Journal, v. 5, 25-29, 1999.

TOLONE, W. J. Virtual situation rooms: connecting people across enterprises for supply-chain agility. Computer-Aided Design v. 32 (2), 109-117, 2000. UMBLE, E. J.; HAFT, R. R.; UMBLE, M. M. Enterprise resource planning: Implementation procedures and critical success factors. European Journal of Operational Research, v. 146(2), p. 241-257, 2003.

TREACY, M.; WIERSEMA, F. Customer intimacy and other value disciplines. Harvard Business Review, January-February, 1993. 
van HOEK, R. I., HARRISON, A., CHRISTOPHER, M. Measuring agile capabilities in the supply chain. International Journal of Operations and Production Management v. 21 (1/2), 126-147, 2001.

VASTAG, G.; KASARDA, J. D. ; BOONE, T. Logistical support for manufacturing agility in global markets. International Journal of Operations and Production Management v. 14 (11), 73-85, 1994.

VELASCO ACOSTA, A. P.; MASCLE, C.; BAPTISTE, P. Applicability of DemandDriven MRP in a complex manufacturing environment. International Journal of Production Research, v. 0, n. 0, p. 1-13, 2019.

VERDOUW, C. N.; BEULENS, A. J. M.; TRIENEKENS, J.H.; van der VORST, J. G. A. J. A framework for modelling business processes in demand-driven supply chains, Production Planning \& Control, v. 22 (4), 365-388, 2011. VICKERY, S. K.; CALANTONE, R.; DROGE, C. Supply chain flexibility: an empirical study, Journal of Supply Chain Management, v. 35 No. 3, pp. 16-24, 1999.

VOLTOLINI, E. Convergência entre cadeia de suprimentos ágil e gestão colaborativa da demanda. 2010. 288 f. Tese de Doutorado em Engenharia de Produção - Programa de Pós-Graduação em Engenharia de Produção, Universidade Federal de Santa Catarina; orientador, Carlos Manuel Taboada Rodriguez. - Florianópolis, SC, 2010.

VOSS, C.; TSIKRIKTSIS, N.; FROHLICH, M. Case research in operations management. International journal of operations \& production management, v. 22, n. 2, p. 195-219, 2002.

WILSON, F.; DESMOND, J.; ROBERTS, H. Success and Failure of MRP II Implementation. British Journal of Management, v. 5, n. 3, p. 221-240, 1994.

YIN, R. K. Estudo de caso: planejamento e métodos. 2. Ed. Porto Alegre: Bookman, 2001.

YU, C.; XU, X.; LU, Y. Computer-integrated manufacturing, cyber-physical systems and cloud manufacturing - concepts and relationships. Manufacturing Letters v. 6, 5-9, 2015. 
YUSUF, Y.; GUNASEKARAN, A.; ABTHORPE, M. S. Enterprise information systems project implementation: A case study of ERP in Rolls-Royce. International Journal of Production Economics, v. 87, n. 3, p. 251-266, 2004.

YUSUF, Y. Y. et al. A relational study of supply chain agility, competitiveness and business performance in the oil and gas industry. International Journal of Production Economics, v. 147, n. PART B, p. 531-543, 2014.

YUSUF, Y. Y.; LITTLE, D. An empirical investigation of enterprise-wide integration of MRPII. International Journal of Operations and Production Management, v. 18, 66-86, 1998.

YUSUF, Y. Y.; SARHADI, M.; GUNASEKARAN, A. Agile manufacturing: the drivers, concepts and attributes. International Journal of Production Economics v. 62 (1/2), 33-43, 1999.

ZADEH, L. A. Fuzzy sets. Information and Control, v.8, p. 338-353, 1965. 


\section{APÊNDICE A - QUESTIONÁRIO PARA OS ESPECIALISTAS}

\section{Elementos de implementação do DDMRP}

Apresentação do questionário

Este questionário faz parte do desenvolvimento de uma pesquisa acadêmica de mestrado sobre fatores de implementação do DDMRP - Demand Driven Material Requirements Planning e será usado apenas para fins acadêmicos. Esta pesquisa deve levar apenas entre 10 a 15 minutos para ser concluída. Tenha certeza de que a identidade de todos os participantes será mantida com a mais estrita confidencialidade.

Agradecemos sua disposição em participar da pesquisa, sendo muito importante para o desenvolvimento do trabalho!

\section{Termo de consentimento de pesquisa}

Desta forma, concordo em participar desta pesquisa de mestrado para fins acadêmicos.

Instruções: os respondentes devem avaliar os fatores de implementação do DDMRP (perguntas 2, 4 e 6) conforme sua experiência, não é necessário alto grau de reflexão para as avaliações pois o método a ser usado posteriormente para a análise dos dados, o Fuzzy Delphi, considera o grau de incerteza nas respostas dos especialistas.

As perguntas com asterisco são obrigatórias pois são essenciais para a pesquisa.

\section{Identificação}

- NOME:

- EMPRESA: 
- SETOR DA EMPRESA (SE APLICÁVEL):

- tempo de experiência com gestão da pROdução (SE APLICÁVEL):

- TEMPO DE EXPERIÊNCIA COM O DDMRP (SE APLICÁVEL):

- há quANTO TEMPO a EMPRESA iniciou a ADOÇÃo dO DDMRP (SE APLICÁVEL)?

- qual é o tipo de REsposta à demanda do sistema de PRODUÇÃO EX: ETO - ENGINEERING TO ORDER; ATO - ASSEMBLE TO ORDER; MTS - MAKE TO STOCK; MTO - MAKE TO ORDER; (SE APLICÁVEL)?

- qual é ou ERA O Sistema usado para GERAÇÃo de ORDENS de PRODUÇÃO ANTES DO DDMRP (KANBAN, MRP, ETC.) (SE APLICÁVEL)?

* 3. Os itens a seguir apresentam motivações para a implementação do DDMRP. Avalie o grau de importância de cada motivação em uma escala de 1 a 5.

\begin{tabular}{|c|c|c|c|c|c|}
\hline Motivações para implementação do DDMRP & 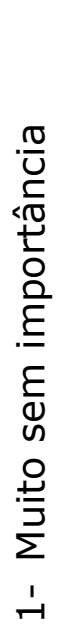 & 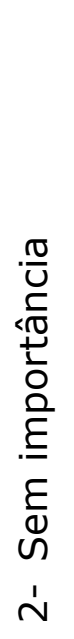 & 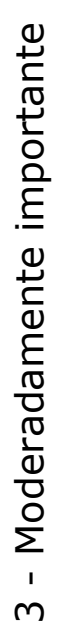 & 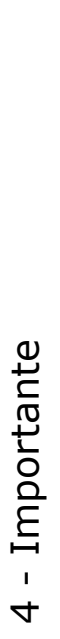 & 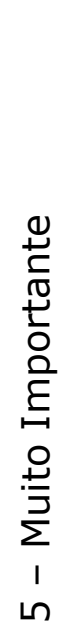 \\
\hline \multicolumn{6}{|l|}{ Redução / controle de inventário } \\
\hline \multicolumn{6}{|l|}{ Redução de custo operacional } \\
\hline \multicolumn{6}{|l|}{ Reduzir lead time da manufatura } \\
\hline \multicolumn{6}{|l|}{$\begin{array}{l}\text { Reduzir / eliminar taxa de stock-out (quebras de } \\
\text { estoques) }\end{array}$} \\
\hline Reduzir a instabilidade do sistema MRP & & & & & \\
\hline
\end{tabular}




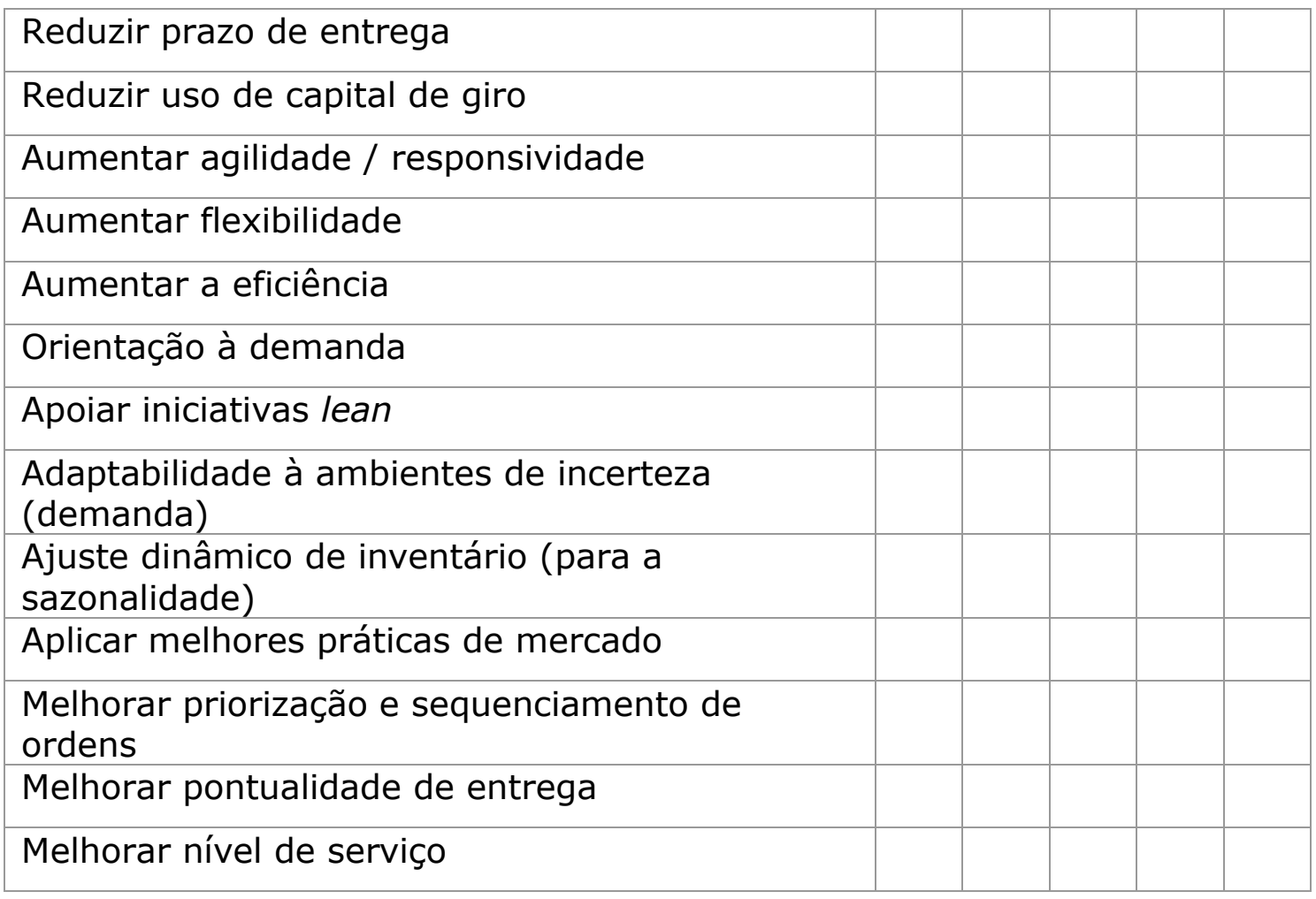

4. Existe alguma outra motivação ou observação que julgue pertinente ser feita sobre os motivos para escolha do DDMRP?

* 5. Os itens a seguir apresentam barreiras ou dificuldades na implementação do DDMRP. Avalie em uma escala de 1 a 5 qual o grau de relevância de cada barreira / dificuldade para a implementação do DDMRP.

\begin{tabular}{|c|c|c|c|c|c|}
\hline $\begin{array}{c}\text { Barreiras/ dificuldade para implementação } \\
\text { do DDMRP }\end{array}$ & 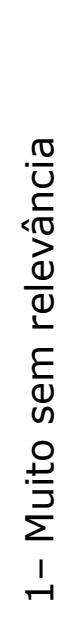 & 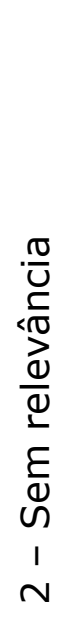 & 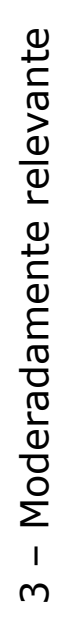 & 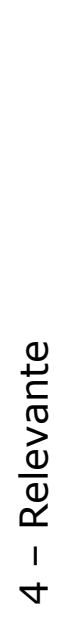 & 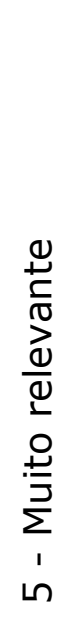 \\
\hline \multicolumn{6}{|l|}{ Falta de conhecimento do método } \\
\hline Falta de precisão nos dados & & & & & \\
\hline
\end{tabular}




\begin{tabular}{|c|c|c|c|c|c|}
\hline $\begin{array}{l}\text { Barreiras/ dificuldade para implementação } \\
\text { do DDMRP }\end{array}$ & 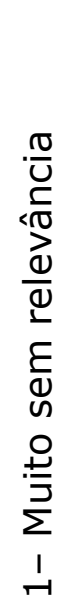 & 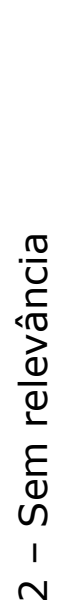 & 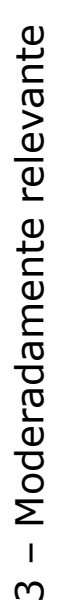 & 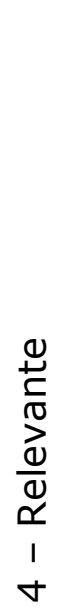 & 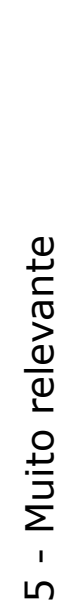 \\
\hline \multicolumn{6}{|l|}{ Falta de suporte da alta gerência } \\
\hline \multicolumn{6}{|l|}{ Falta de suporte do fornecedor do sistema } \\
\hline \multicolumn{6}{|l|}{ Falta de comprometimento dos funcionários } \\
\hline \multicolumn{6}{|l|}{ Falta de treinamento } \\
\hline \multicolumn{6}{|l|}{ Falta de recursos humanos } \\
\hline \multicolumn{6}{|l|}{ Falta de tempo disponível } \\
\hline \multicolumn{6}{|l|}{ Falta de apoio de consultores externos } \\
\hline \multicolumn{6}{|l|}{$\begin{array}{l}\text { Falta de compartilhamento de informações entre } \\
\text { departamentos }\end{array}$} \\
\hline \multicolumn{6}{|l|}{ Falta de prazos e metas claras } \\
\hline \multicolumn{6}{|l|}{$\begin{array}{l}\text { Falta de experiência dos funcionários com o } \\
\text { sistema de produção da empresa }\end{array}$} \\
\hline \multicolumn{6}{|l|}{$\begin{array}{l}\text { Dificuldade na reconfiguração da produção } \\
\text { (layout) }\end{array}$} \\
\hline \multicolumn{6}{|l|}{ Dificuldade em posicionar os buffers } \\
\hline \multicolumn{6}{|l|}{ Dificuldade em dimensionar os buffers } \\
\hline \multicolumn{6}{|l|}{$\begin{array}{l}\text { Dificuldade em estabelecer o PAF (fator de ajuste } \\
\text { planejado) para sazonalidade }\end{array}$} \\
\hline \multicolumn{6}{|l|}{ Dificuldade em aplicar a gestão visual } \\
\hline \multicolumn{6}{|l|}{$\begin{array}{l}\text { Dificuldade em adaptar o DDMRP ao sistema de } \\
\text { resposta à demanda adotado pela empresa }\end{array}$} \\
\hline $\begin{array}{l}\text { Incompatibilidade com outros sistemas da } \\
\text { empresa }\end{array}$ & & & & & \\
\hline
\end{tabular}




\begin{tabular}{|c|c|c|c|c|c|}
\hline $\begin{array}{c}\text { Barreiras/ dificuldade para implementação } \\
\text { do DDMRP }\end{array}$ & 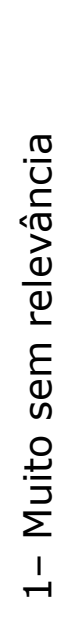 & 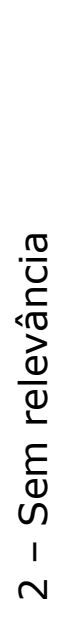 & 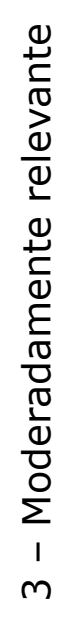 & 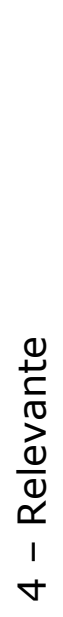 & 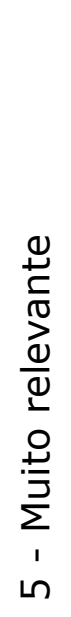 \\
\hline \multicolumn{6}{|l|}{$\begin{array}{l}\text { Incompatibilidade com o mercado de atuação da } \\
\text { empresa }\end{array}$} \\
\hline \multicolumn{6}{|l|}{ Choque cultural } \\
\hline \multicolumn{6}{|l|}{ Customizações requisitadas no sistema } \\
\hline \multicolumn{6}{|l|}{ Custo elevado } \\
\hline \multicolumn{6}{|l|}{ Complexidade do projeto / mudança } \\
\hline Resistência a mudança & & & & & \\
\hline
\end{tabular}

6. Foram encontradas outras barreiras ou dificuldades durante 0 processo de implementação além das listadas, ou alguma observação que gostaria de fazer a respeito desse tema? 
* 7. Os itens a seguir apresentam fatores críticos de sucesso da implementação do DDMRP. Avalie em uma escala de 1 a 5 o grau de importância de cada fator para o sucesso da implementação do DDMRP.

\begin{tabular}{|c|c|c|c|c|c|}
\hline $\begin{array}{l}\text { Fatores críticos de sucesso para } \\
\text { implementação do DDMRP }\end{array}$ & 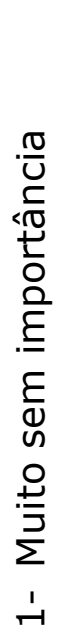 & 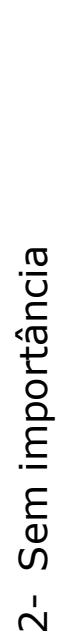 & 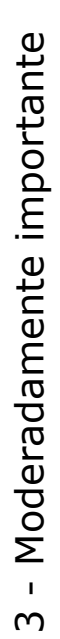 & 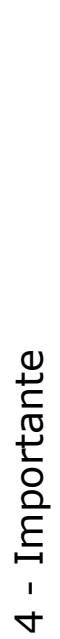 & 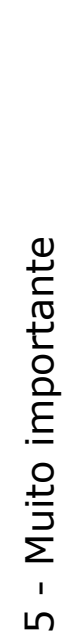 \\
\hline \multicolumn{6}{|l|}{ Apoio da alta gerência } \\
\hline \multicolumn{6}{|l|}{ Treinamento e educação } \\
\hline \multicolumn{6}{|l|}{ Planejamento e gestão de projeto } \\
\hline \multicolumn{6}{|l|}{ Planejamento de longo prazo } \\
\hline \multicolumn{6}{|l|}{ Suporte de consultores externos } \\
\hline \multicolumn{6}{|l|}{ Suporte do fornecedor do sistema } \\
\hline \multicolumn{6}{|l|}{ Disponibilidade de recursos } \\
\hline \multicolumn{6}{|l|}{ Precisão e integridade dos dados } \\
\hline \multicolumn{6}{|l|}{ Adequação do hardware e software } \\
\hline \multicolumn{6}{|l|}{ Adequação do DDMRP ao mercado da empresa } \\
\hline \multicolumn{6}{|l|}{ Adequação do DDMRP à filosofia da empresa } \\
\hline \multicolumn{6}{|l|}{$\begin{array}{l}\text { Adequação do DDMRP ao tipo de resposta à } \\
\text { demanda da empresa }\end{array}$} \\
\hline \multicolumn{6}{|l|}{ Metas e objetivos claros } \\
\hline \multicolumn{6}{|l|}{ Motivação e comprometimento da equipe } \\
\hline \multicolumn{6}{|l|}{ Comunicação e engajamento } \\
\hline \multicolumn{6}{|l|}{ Conhecimento técnico aprofundado do método } \\
\hline Compartilhamento de informações & & & & & \\
\hline
\end{tabular}




\begin{tabular}{|c|c|c|c|c|c|}
\hline $\begin{array}{l}\text { Fatores críticos de sucesso para } \\
\text { implementação do DDMRP }\end{array}$ & 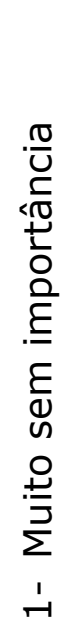 & 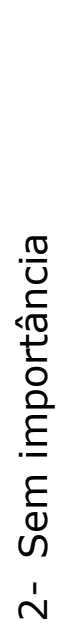 & 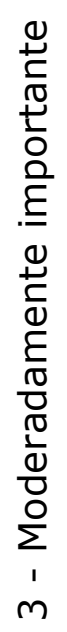 & 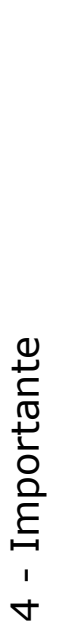 & 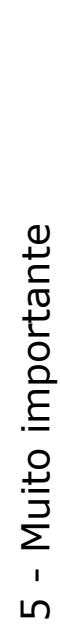 \\
\hline \multicolumn{6}{|l|}{ Cultura organizacional proativa } \\
\hline Experiência dos colaboradores com a empresa & & & & & \\
\hline
\end{tabular}

8. Há outros fatores críticos que considere que foram importantes para o sucesso da implementação que não foram listados acima, ou alguma observação que gostaria de fazer? 


\section{APÊNDICE B - CÁLCULOS DO MÉTODO FUZZY DELPHI}

Agregação das respostas em escala fuzzy para as motivações.

\begin{tabular}{|c|c|c|c|c|c|c|c|c|c|c|c|c|c|c|c|c|c|c|c|c|}
\hline \multicolumn{21}{|c|}{ Agregação pela média - Motivações } \\
\hline \multicolumn{3}{|c|}{ M1 } & \multicolumn{3}{|c|}{ M2 } & \multicolumn{3}{|c|}{ M3 } & \multicolumn{3}{|c|}{ M4 } & \multicolumn{3}{|c|}{ M5 } & \multicolumn{3}{|c|}{ M6 } & \multicolumn{3}{|c|}{ M7 } \\
\hline 0,62 & 0,87 & 0,98 & 0,39 & 0,64 & 0,85 & 0,48 & 0,71 & 0,88 & 0,64 & 0,89 & 0,95 & 0,46 & 0,70 & 0,87 & 0,44 & 0,69 & 0,87 & 0,58 & 0,83 & 0,95 \\
\hline \multicolumn{3}{|c|}{ M8 } & \multicolumn{3}{|c|}{ M9 } & \multicolumn{3}{|c|}{ M10 } & \multicolumn{3}{|c|}{ M11 } & \multicolumn{3}{|c|}{ M12 } & \multicolumn{3}{|c|}{ M13 } & \multicolumn{3}{|c|}{ M14 } \\
\hline 0,57 & 0,82 & 0,97 & 0,52 & 0,77 & 0,95 & 0,45 & 0,70 & 0,90 & 0,56 & 0,81 & 0,92 & 0,27 & 0,49 & 0,73 & 0,55 & 0,80 & 0,94 & 0,59 & 0,84 & 0,95 \\
\hline \multicolumn{3}{|c|}{ M15 } & \multicolumn{3}{|c|}{ M16 } & \multicolumn{3}{|c|}{ M17 } & \multicolumn{3}{|c|}{ M18 } & & & & & & & & & \\
\hline 0,36 & 0,61 & 0,82 & 0,52 & 0,77 & 0,92 & 0,62 & 0,87 & 0,98 & 0,68 & 0,93 & 1,00 & & & & & & & & & \\
\hline
\end{tabular}

Agregação das respostas em escala fuzzy para as barreiras.

\begin{tabular}{|c|c|c|c|c|c|c|c|c|c|c|c|c|c|c|c|c|c|c|c|c|}
\hline \multicolumn{21}{|c|}{ Agregação pela média - Barreiras } \\
\hline \multicolumn{3}{|c|}{ B1 } & \multicolumn{3}{|c|}{ B2 } & \multicolumn{3}{|c|}{ B3 } & \multicolumn{3}{|c|}{ B4 } & \multicolumn{3}{|c|}{ B5 } & \multicolumn{3}{|c|}{ B6 } & \multicolumn{3}{|c|}{ B7 } \\
\hline 0,48 & 0,73 & 0,89 & 0,40 & 0,64 & 0,82 & 0,49 & 0,73 & 0,86 & 0,29 & 0,50 & 0,70 & 0,42 & 0,66 & 0,85 & 0,41 & 0,65 & 0,83 & 0,28 & 0,52 & 0,75 \\
\hline \multicolumn{3}{|c|}{ B8 } & \multicolumn{3}{|c|}{ B9 } & \multicolumn{3}{|c|}{ B10 } & \multicolumn{3}{|c|}{ B11 } & \multicolumn{3}{|c|}{ B12 } & \multicolumn{3}{|c|}{ B13 } & \multicolumn{3}{|c|}{ B14 } \\
\hline 0,33 & 0,57 & 0,79 & 0,24 & 0,46 & 0,70 & 0,31 & 0,55 & 0,77 & 0,35 & 0,59 & 0,79 & 0,27 & 0,50 & 0,74 & 0,25 & 0,47 & 0,70 & 0,30 & 0,53 & 0,74 \\
\hline \multicolumn{3}{|c|}{ B15 } & \multicolumn{3}{|c|}{ B16 } & \multicolumn{3}{|c|}{ B17 } & \multicolumn{3}{|c|}{ B18 } & \multicolumn{3}{|c|}{ B19 } & \multicolumn{3}{|c|}{ B20 } & \multicolumn{3}{|c|}{ B21 } \\
\hline 0,27 & 0,50 & 0,72 & 0,30 & 0,52 & 0,74 & 0,28 & 0,51 & 0,75 & 0,33 & 0,57 & 0,78 & 0,29 & 0,51 & 0,73 & 0,14 & 0,32 & 0,57 & 0,44 & 0,69 & 0,88 \\
\hline \multicolumn{3}{|c|}{ B22 } & \multicolumn{3}{|c|}{ B23 } & \multicolumn{3}{|c|}{ B24 } & \multicolumn{3}{|c|}{ B25 } & & & & & & & & & \\
\hline 0,36 & 0,61 & 0,83 & 0,17 & 0,41 & 0,65 & 0,36 & 0,61 & 0,80 & 0,52 & 0,76 & 0,92 & & & & & & & & & \\
\hline
\end{tabular}


Agregação das respostas em escala fuzzy para os fatores críticos de sucesso.

\begin{tabular}{|c|c|c|c|c|c|c|c|c|c|c|c|c|c|c|c|c|c|c|c|c|}
\hline \multicolumn{21}{|c|}{ Agregação pela média - Fatores críticos de sucesso } \\
\hline \multicolumn{3}{|c|}{ FC1 } & \multicolumn{3}{|c|}{ FC2 } & \multicolumn{3}{|c|}{ FC3 } & \multicolumn{3}{|c|}{ FC4 } & \multicolumn{3}{|c|}{ FC5 } & \multicolumn{3}{|c|}{ FC6 } & \multicolumn{3}{|c|}{ FC7 } \\
\hline 0,70 & 0,95 & 1,00 & 0,69 & 0,94 & 1,00 & 0,55 & 0,80 & 0,96 & 0,43 & 0,68 & 0,89 & 0,52 & 0,77 & 0,93 & 0,49 & 0,73 & 0,91 & 0,48 & 0,73 & 0,92 \\
\hline \multicolumn{3}{|c|}{ FC8 } & \multicolumn{3}{|c|}{ FC9 } & \multicolumn{3}{|c|}{ FC10 } & \multicolumn{3}{|c|}{ FC11 } & \multicolumn{3}{|c|}{ FC12 } & \multicolumn{3}{|c|}{ FC13 } & \multicolumn{3}{|c|}{ FC14 } \\
\hline 0,59 & 0,83 & 0,94 & 0,45 & 0,70 & 0,89 & 0,39 & 0,64 & 0,85 & 0,44 & 0,69 & 0,89 & 0,50 & 0,75 & 0,92 & 0,61 & 0,86 & 0,97 & 0,60 & 0,85 & 0,99 \\
\hline \multicolumn{3}{|c|}{ FC15 } & \multicolumn{3}{|c|}{ FC16 } & \multicolumn{3}{|c|}{ FC17 } & \multicolumn{3}{|c|}{ FC18 } & \multicolumn{3}{|c|}{ FC19 } & & & & & & \\
\hline 0,61 & 0,86 & 0,98 & 0,60 & 0,85 & 0,96 & 0,47 & 0,72 & 0,91 & 0,48 & 0,72 & 0,89 & 0,41 & 0,66 & 0,89 & & & & & & \\
\hline
\end{tabular}

Desfuzzificação dos valores fuzzy agregados - motivações.

\begin{tabular}{|c|c|c|c|c|c|c|c|c|c|c|c|c|c|c|c|c|c|c|}
\hline & M1 & M2 & M3 & M4 & M5 & M6 & M7 & M8 & M9 & M10 & M11 & M12 & M13 & M14 & M15 & M16 & M17 & M18 \\
\hline$x_{m}^{1}$ & 0,82 & 0,63 & 0,69 & 0,83 & 0,68 & 0,67 & 0,78 & 0,79 & 0,75 & 0,69 & 0,77 & 0,50 & 0,76 & 0,79 & 0,60 & 0,73 & 0,82 & 0,87 \\
\hline$x_{m}^{2}$ & 0,84 & 0,63 & 0,70 & 0,85 & 0,68 & 0,67 & 0,79 & 0,79 & 0,75 & 0,69 & 0,78 & 0,50 & 0,77 & 0,80 & 0,60 & 0,74 & 0,84 & 0,89 \\
\hline$x_{m}^{3}$ & 0,85 & 0,64 & 0,70 & 0,86 & 0,69 & 0,68 & 0,80 & 0,80 & 0,76 & 0,70 & 0,79 & 0,49 & 0,78 & 0,82 & 0,60 & 0,75 & 0,85 & 0,90 \\
\hline $\mathrm{Zi}$ & 0,85 & 0,64 & 0,70 & 0,86 & 0,69 & 0,68 & 0,80 & 0,80 & 0,76 & 0,70 & 0,79 & 0,50 & 0,78 & 0,82 & 0,60 & 0,75 & 0,85 & 0,90 \\
\hline
\end{tabular}

Desfuzzificação dos valores fuzzy agregados - barreiras.

\begin{tabular}{|c|c|c|c|c|c|c|c|c|c|c|c|c|c|c|c|c|c|c|}
\hline & 1 & 2 & 3 & 4 & 5 & 6 & B7 & B8 & B9 & 10 & B11 & 12 & B13 & B14 & 315 & B16 & B17 & B18 \\
\hline$x_{n}^{1}$ & 0 & 62 & 70 & 49 & 64 & 63 & 52 & 56 & 47 & 55 & 0,58 & 50 & & 53 & 50 & 52 & 51 & ,56 \\
\hline$x_{m}^{2}$ & 71 & 62 & 71 & 05 & 5 & 64 & 52 & 6 & 0,47 & 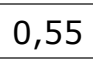 & 0 , & 50 & 047 & 53 & 0,50 & 2 & 1 &, 56 \\
\hline$x_{m}^{3}$ & 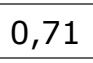 & 3 & - & r & 0 & 0,64 & 0,52 & 6 & & 0, & 0 , & 0,50 & & 3 & 0 & 52 & 0,51 & 0,56 \\
\hline $\mathrm{Zi}$ & 0,71 & 0,63 & 0,72 & 0,50 & 0,65 & 0,64 & 0,52 & 0,56 & 0,47 & 0,55 & 0,58 & 0,50 & 0,47 & 0,53 & 0,50 & 0,52 & 0,51 & 0,56 \\
\hline
\end{tabular}




\begin{tabular}{cccccccc}
\hline & B19 & B20 & B21 & B22 & B23 & B24 & B25 \\
\hline$x_{m}^{1}$ & 0,51 & 0,34 & 0,67 & 0,6 & 0,41 & 0,59 & 0,73 \\
\hline$x_{m}^{2}$ & 0,51 & 0,34 & 0,67 & 0,6 & 0,41 & 0,59 & 0,74 \\
\hline$x_{m}^{3}$ & 0,51 & 0,33 & 0,68 & 0,61 & 0,41 & 0,6 & 0,74 \\
\hline $\mathrm{Zi}$ & 0,51 & 0,34 & 0,68 & 0,61 & 0,41 & 0,60 & 0,74 \\
\hline
\end{tabular}

Desfuzzificação dos valores fuzzy agregados - fatores críticos de sucesso.

\begin{tabular}{|c|c|c|c|c|c|c|c|c|c|c|c|c|c|c|c|c|c|c|c|}
\hline & FC1 & FC2 & FC3 & FC4 & FC5 & FC6 & FC7 & FC8 & FC9 & FC10 & FC11 & FC12 & FC13 & FC14 & FC15 & FC16 & FC17 & FC18 & FC19 \\
\hline$x_{m}^{1}$ & 0,89 & 0,88 & 0,77 & 0,67 & 0,74 & 0,71 & 0,71 & 0,79 & 0,68 & 0,63 & 0,67 & 0,72 & 0,81 & 0,81 & 0,82 & 0,80 & 0,70 & 0,69 & 0,65 \\
\hline$x_{m}^{2}$ & 0,90 & 0,89 & 0,77 & 0,67 & 0,75 & 0,72 & 0,71 & 0,80 & 0,68 & 0,63 & 0,68 & 0,73 & 0,82 & 0,82 & 0,83 & 0,81 & 0,70 & 0,70 & 0,65 \\
\hline$x_{m}^{3}$ & 0,92 & 0,91 & 0,78 & 0,67 & 0,76 & 0,72 & 0,72 & 0,81 & 0,69 & 0,64 & 0,68 & 0,74 & 3 & 0, & 0,84 & 0,83 & 0,71 & 0,71 & 0,66 \\
\hline $\mathrm{Zi}$ & 0,92 & 0,91 & 0,78 & 0,67 & 0,76 & 0,72 & 0,72 & 0,81 & 0,69 & 0,64 & 0,68 & 0,74 & 0,83 & 0,83 & 0,84 & 0,83 & 0,71 & 0,71 & 0,66 \\
\hline
\end{tabular}

Último passo, cálculo dos valores "Threshold value $d$ " e índice de consenso.

\begin{tabular}{|c|c|c|c|c|c|c|c|c|c|c|c|c|c|c|c|c|c|c|}
\hline \multirow{2}{*}{ Esp. } & \multicolumn{18}{|c|}{ Threshold value d - MOTIVAÇÕES } \\
\hline & M1 & M2 & M3 & M4 & M5 & M6 & M7 & M8 & M9 & M10 & M11 & M12 & M13 & M14 & M15 & M16 & M17 & M18 \\
\hline 1 & 0,11 & 0,13 & 0,07 & 0,09 & 0,08 & 0,26 & 0,15 & 0,06 & 0,04 & 0,19 & 0,16 & 0,25 & 0,17 & 0,13 & 0,16 & 0,05 & 0,11 & 0,06 \\
\hline 2 & 0,33 & 0,13 & 0,19 & 0,34 & 0,60 & 0,42 & 0,54 & 0,06 & 0,04 & 0,07 & 0,07 & 0,43 & 0,05 & 0,13 & 0,35 & 0,05 & 0,11 & 0,06 \\
\hline 3 & 0,11 & 0,30 & 0,07 & 0,09 & 0,18 & 0,09 & 0,15 & 0,15 & 0,04 & 0,19 & 0,07 & 0,25 & 0,05 & 0,08 & 0,34 & 0,20 & 0,11 & 0,06 \\
\hline 4 & 0,10 & 0,13 & 0,07 & 0,59 & 0,43 & 0,26 & 0,29 & 0,06 & 0,25 & 0,19 & 0,27 & 0,25 & 0,51 & 0,30 & 0,16 & 0,05 & 0,10 & 0,06 \\
\hline 5 & 0,11 & 0,12 & 0,44 & 0,09 & 0,25 & 0,17 & 0,07 & 0,29 & 0,04 & 0,07 & 0,16 & 0,01 & 0,17 & 0,13 & 0,10 & 0,20 & 0,11 & 0,06 \\
\hline 6 & 0,11 & 0,30 & 0,07 & 0,09 & 0,08 & 0,09 & 0,15 & 0,06 & 0,04 & 0,25 & 0,16 & 0,01 & 0,05 & 0,08 & 0,16 & 0,05 & 0,11 & 0,06 \\
\hline 7 & 0,10 & 0,13 & 0,24 & 0,09 & 0,18 & 0,26 & 0,07 & 0,15 & 0,19 & 0,19 & 0,27 & 0,25 & 0,05 & 0,08 & 0,35 & 0,49 & 0,11 & 0,06 \\
\hline 8 & 0,11 & 0,30 & 0,24 & 0,09 & 0,08 & 0,17 & 0,15 & 0,06 & 0,04 & 0,07 & 0,16 & 0,25 & 0,17 & 0,13 & 0,34 & 0,20 & 0,10 & 0,15 \\
\hline 9 & 0,11 & 0,13 & 0,24 & 0,09 & 0,25 & 0,17 & 0,15 & 0,15 & 0,19 & 0,07 & 0,16 & 0,01 & 0,17 & 0,13 & 0,35 & 0,20 & 0,11 & 0,06 \\
\hline 10 & 0,11 & 0,13 & 0,07 & 0,12 & 0,18 & 0,17 & 0,15 & 0,06 & 0,04 & 0,19 & 0,07 & 0,01 & 0,26 & 0,30 & 0,10 & 0,24 & 0,10 & 0,06 \\
\hline
\end{tabular}




\begin{tabular}{|c|c|c|c|c|c|c|c|c|c|c|c|c|c|c|c|c|c|c|}
\hline \multirow{2}{*}{ Esp. } & \multicolumn{18}{|c|}{ Threshold value d - MOTIVAÇÕES } \\
\hline & M1 & M2 & M3 & M4 & M5 & M6 & M7 & M8 & M9 & M10 & M11 & M12 & M13 & M14 & M15 & M16 & M17 & M18 \\
\hline 11 & 0,10 & 0,13 & 0,19 & 0,09 & 0,18 & 0,09 & 0,29 & 0,06 & 0,04 & 0,07 & 0,52 & 0,25 & 0,05 & 0,13 & 0,35 & 0,20 & 0,11 & 0,06 \\
\hline 12 & 0,10 & 0,13 & 0,61 & 0,09 & 0,18 & 0,17 & 0,07 & 0,15 & 0,19 & 0,07 & 0,16 & 0,25 & 0,17 & 0,13 & 0,16 & 0,24 & 0,33 & 0,15 \\
\hline 13 & 0,10 & 0,30 & 0,19 & 0,09 & 0,25 & 0,09 & 0,07 & 0,15 & 0,19 & 0,25 & 0,27 & 0,01 & 0,05 & 0,08 & 0,16 & 0,24 & 0,11 & 0,06 \\
\hline 14 & 0,10 & 0,13 & 0,24 & 0,09 & 0,08 & 0,17 & 0,07 & 0,06 & 0,04 & 0,07 & 0,27 & 0,25 & 0,17 & 0,13 & 0,16 & 0,05 & 0,10 & 0,06 \\
\hline 15 & 0,33 & 0,12 & 0,19 & 0,09 & 0,08 & 0,17 & 0,07 & 0,06 & 0,04 & 0,07 & 0,16 & 0,01 & 0,05 & 0,13 & 0,10 & 0,05 & 0,11 & 0,06 \\
\hline 16 & 0,10 & 0,12 & 0,24 & 0,09 & 0,08 & 0,26 & 0,07 & 0,15 & 0,04 & 0,07 & 0,16 & 0,25 & 0,17 & 0,13 & 0,16 & 0,05 & 0,11 & 0,06 \\
\hline 17 & 0,10 & 0,12 & 0,24 & 0,12 & 0,25 & 0,09 & 0,29 & 0,06 & 0,19 & 0,25 & 0,16 & 0,25 & 0,26 & 0,13 & 0,16 & 0,20 & 0,10 & 0,15 \\
\hline 18 & 0,10 & 0,12 & 0,24 & 0,34 & 0,25 & 0,09 & 0,15 & 0,06 & 0,25 & 0,07 & 0,27 & 0,25 & 0,26 & 0,08 & 0,10 & 0,20 & 0,10 & 0,06 \\
\hline 19 & 0,11 & 0,30 & 0,24 & 0,09 & 0,25 & 0,26 & 0,15 & 0,15 & 0,19 & 0,25 & 0,16 & 0,43 & 0,17 & 0,13 & 0,34 & 0,20 & 0,11 & 0,06 \\
\hline 20 & 0,11 & 0,30 & 0,07 & 0,12 & 0,08 & 0,17 & 0,29 & 0,06 & 0,04 & 0,07 & 0,16 & 0,25 & 0,05 & 0,08 & 0,16 & 0,05 & 0,10 & 0,15 \\
\hline 21 & 0,10 & 0,38 & 0,24 & 0,09 & 0,43 & 0,26 & 0,07 & 0,15 & 0,19 & 0,44 & 0,16 & 0,01 & 0,17 & 0,13 & 0,35 & 0,24 & 0,11 & 0,06 \\
\hline 22 & 0,11 & 0,13 & 0,07 & 0,09 & 0,43 & 0,42 & 0,15 & 0,54 & 0,50 & 0,07 & 0,52 & 0,25 & 0,51 & 0,55 & 0,35 & 0,49 & 0,11 & 0,06 \\
\hline 23 & 0,11 & 0,13 & 0,61 & 0,09 & 0,08 & 0,09 & 0,15 & 0,06 & 0,04 & 0,07 & 0,07 & 0,43 & 0,05 & 0,08 & 0,16 & 0,05 & 0,10 & 0,06 \\
\hline 24 & 0,11 & 0,12 & 0,24 & 0,34 & 0,08 & 0,26 & 0,29 & 0,15 & 0,25 & 0,25 & 0,16 & 0,01 & 0,17 & 0,08 & 0,34 & 0,20 & 0,10 & 0,06 \\
\hline 25 & 0,11 & 0,38 & 0,44 & 0,09 & 0,08 & 0,17 & 0,15 & 0,29 & 0,50 & 0,19 & 0,07 & 0,25 & 0,17 & 0,13 & 0,10 & 0,24 & 0,11 & 0,06 \\
\hline 26 & 0,11 & 0,12 & 0,07 & 0,09 & 0,25 & 0,17 & 0,15 & 0,15 & 0,19 & 0,25 & 0,16 & 0,01 & 0,17 & 0,13 & 0,34 & 0,05 & 0,11 & 0,06 \\
\hline 27 & 0,11 & 0,12 & 0,19 & 0,09 & 0,25 & 0,26 & 0,15 & 0,06 & 0,04 & 0,19 & 0,16 & 0,25 & 0,17 & 0,13 & 0,16 & 0,05 & 0,11 & 0,06 \\
\hline 28 & 0,33 & 0,12 & 0,19 & 0,09 & 0,60 & 0,17 & 0,15 & 0,06 & 0,04 & 0,25 & 0,27 & 0,01 & 0,05 & 0,30 & 0,10 & 0,05 & 0,33 & 0,15 \\
\hline 29 & 0,11 & 0,13 & 0,07 & 0,09 & 0,08 & 0,09 & 0,07 & 0,15 & 0,04 & 0,19 & 0,16 & 0,25 & 0,26 & 0,30 & 0,10 & 0,20 & 0,10 & 0,15 \\
\hline 30 & 0,11 & 0,12 & 0,07 & 0,09 & 0,25 & 0,09 & 0,15 & 0,06 & 0,04 & 0,07 & 0,16 & 0,25 & 0,05 & 0,13 & 0,16 & 0,20 & 0,11 & 0,15 \\
\hline 31 & 0,11 & 0,38 & 0,24 & 0,09 & 0,08 & 0,26 & 0,15 & 0,15 & 0,19 & 0,44 & 0,16 & 0,43 & 0,17 & 0,13 & 0,52 & 0,05 & 0,11 & 0,06 \\
\hline 32 & 0,10 & 0,13 & 0,07 & 0,09 & 0,25 & 0,09 & 0,07 & 0,15 & 0,19 & 0,07 & 0,07 & 0,25 & 0,05 & 0,30 & 0,16 & 0,24 & 0,10 & 0,15 \\
\hline 33 & 0,11 & 0,13 & 0,07 & 0,34 & 0,08 & 0,42 & 0,15 & 0,06 & 0,04 & 0,19 & 0,07 & 0,25 & 0,05 & 0,13 & 0,35 & 0,20 & 0,33 & 0,15 \\
\hline d Médio & 0,12 & 0,18 & 0,21 & 0,14 & 0,21 & 0,19 & 0,16 & 0,12 & 0,13 & 0,16 & 0,18 & 0,20 & 0,16 & 0,16 & 0,22 & 0,16 & 0,12 & 0,08 \\
\hline Consenso & 0,91 & 0,73 & 0,55 & 0,85 & 0,55 & 0,64 & 0,82 & 0,91 & 0,85 & 0,73 & 0,76 & 0,30 & 0,82 & 0,82 & 0,61 & 0,76 & 0,91 & 1,00 \\
\hline
\end{tabular}


Threshold value d - BARREIRAS

\begin{tabular}{|c|c|c|c|c|c|c|c|c|c|c|c|c|c|c|c|c|c|c|}
\hline \multirow{2}{*}{ Esp. } & \multicolumn{18}{|c|}{ Threshold value d - BARREIRAS } \\
\hline & B1 & B2 & B3 & B4 & B5 & B6 & B7 & B8 & B9 & B10 & B11 & B12 & B13 & B14 & B15 & B16 & B17 & B18 \\
\hline 1 & 0,06 & 0,14 & 0,23 & 0,04 & 0,29 & 0,12 & 0,23 & 0,19 & 0,28 & 0,21 & 0,18 & 0,25 & 0,03 & 0,04 & 0,02 & 0,03 & 0,02 & 0,19 \\
\hline 2 & 0,06 & 0,37 & 0,45 & 0,25 & 0,39 & 0,38 & 0,27 & 0,31 & 0,22 & 0,30 & 0,33 & 0,25 & 0,23 & 0,04 & 0,25 & 0,45 & 0,26 & 0,06 \\
\hline 3 & 0,21 & 0,31 & 0,23 & 0,43 & 0,29 & 0,12 & 0,23 & 0,37 & 0,46 & 0,05 & 0,18 & 0,01 & 0,03 & 0,04 & 0,02 & 0,03 & 0,02 & 0,37 \\
\hline 4 & 0,45 & 0,37 & 0,45 & 0,25 & 0,39 & 0,38 & 0,02 & 0,06 & 0,22 & 0,30 & 0,08 & 0,25 & 0,03 & 0,04 & 0,02 & 0,03 & 0,02 & 0,31 \\
\hline 5 & 0,21 & 0,31 & 0,45 & 0,25 & 0,11 & 0,12 & 0,02 & 0,06 & 0,22 & 0,30 & 0,33 & 0,01 & 0,03 & 0,28 & 0,25 & 0,27 & 0,02 & 0,31 \\
\hline 6 & 0,06 & 0,14 & 0,23 & 0,43 & 0,11 & 0,14 & 0,23 & 0,19 & 0,28 & 0,05 & 0,18 & 0,01 & 0,28 & 0,23 & 0,25 & 0,23 & 0,02 & 0,19 \\
\hline 7 & 0,06 & 0,12 & 0,23 & 0,25 & 0,14 & 0,12 & 0,02 & 0,06 & 0,28 & 0,21 & 0,08 & 0,01 & 0,23 & 0,28 & 0,25 & 0,27 & 0,26 & 0,31 \\
\hline 8 & 0,23 & 0,14 & 0,08 & 0,43 & 0,29 & 0,12 & 0,41 & 0,37 & 0,03 & 0,38 & 0,35 & 0,25 & 0,03 & 0,04 & 0,02 & 0,41 & 0,24 & 0,37 \\
\hline 9 & 0,23 & 0,12 & 0,23 & 0,25 & 0,39 & 0,30 & 0,45 & 0,49 & 0,40 & 0,21 & 0,35 & 0,43 & 0,40 & 0,45 & 0,43 & 0,45 & 0,24 & 0,31 \\
\hline 10 & 0,21 & 0,14 & 0,23 & 0,43 & 0,11 & 0,38 & 0,27 & 0,19 & 0,22 & 0,30 & 0,33 & 0,25 & 0,28 & 0,28 & 0,43 & 0,41 & 0,24 & 0,37 \\
\hline 11 & 0,23 & 0,14 & 0,21 & 0,04 & 0,11 & 0,12 & 0,02 & 0,31 & 0,03 & 0,05 & 0,18 & 0,25 & 0,03 & 0,40 & 0,43 & 0,41 & 0,42 & 0,06 \\
\hline 12 & 0,63 & 0,37 & 0,21 & 0,42 & 0,39 & 0,38 & 0,27 & 0,19 & 0,40 & 0,30 & 0,33 & 0,25 & 0,23 & 0,45 & 0,25 & 0,45 & 0,44 & 0,31 \\
\hline 13 & 0,23 & 0,12 & 0,23 & 0,42 & 0,11 & 0,12 & 0,02 & 0,06 & 0,28 & 0,05 & 0,18 & 0,25 & 0,40 & 0,45 & 0,43 & 0,45 & 0,44 & 0,49 \\
\hline 14 & 0,06 & 0,31 & 0,21 & 0,04 & 0,11 & 0,14 & 0,02 & 0,06 & 0,28 & 0,21 & 0,33 & 0,25 & 0,28 & 0,04 & 0,25 & 0,27 & 0,02 & 0,37 \\
\hline 15 & 0,06 & 0,31 & 0,23 & 0,43 & 0,11 & 0,12 & 0,23 & 0,37 & 0,28 & 0,21 & 0,35 & 0,01 & 0,03 & 0,04 & 0,02 & 0,27 & 0,02 & 0,31 \\
\hline 16 & 0,06 & 0,14 & 0,21 & 0,26 & 0,11 & 0,14 & 0,23 & 0,19 & 0,22 & 0,05 & 0,18 & 0,01 & 0,28 & 0,04 & 0,02 & 0,23 & 0,24 & 0,19 \\
\hline 17 & 0,21 & 0,37 & 0,08 & 0,26 & 0,11 & 0,14 & 0,23 & 0,06 & 0,28 & 0,05 & 0,33 & 0,25 & 0,23 & 0,28 & 0,25 & 0,03 & 0,02 & 0,19 \\
\hline 18 & 0,06 & 0,31 & 0,23 & 0,25 & 0,14 & 0,38 & 0,02 & 0,19 & 0,22 & 0,21 & 0,08 & 0,25 & 0,03 & 0,04 & 0,02 & 0,27 & 0,02 & 0,06 \\
\hline 19 & 0,23 & 0,31 & 0,23 & 0,43 & 0,29 & 0,30 & 0,41 & 0,37 & 0,03 & 0,21 & 0,35 & 0,43 & 0,28 & 0,40 & 0,25 & 0,23 & 0,24 & 0,19 \\
\hline 20 & 0,06 & 0,14 & 0,23 & 0,43 & 0,11 & 0,12 & 0,27 & 0,31 & 0,28 & 0,21 & 0,08 & 0,01 & 0,03 & 0,23 & 0,43 & 0,41 & 0,24 & 0,19 \\
\hline 21 & 0,23 & 0,12 & 0,08 & 0,42 & 0,14 & 0,30 & 0,02 & 0,06 & 0,40 & 0,47 & 0,50 & 0,25 & 0,45 & 0,40 & 0,43 & 0,23 & 0,02 & 0,19 \\
\hline 22 & 0,21 & 0,37 & 0,21 & 0,25 & 0,11 & 0,14 & 0,27 & 0,31 & 0,22 & 0,30 & 0,33 & 0,25 & 0,23 & 0,28 & 0,25 & 0,27 & 0,26 & 0,31 \\
\hline 23 & 0,21 & 0,31 & 0,21 & 0,25 & 0,39 & 0,38 & 0,27 & 0,06 & 0,22 & 0,21 & 0,33 & 0,25 & 0,03 & 0,28 & 0,25 & 0,23 & 0,26 & 0,19 \\
\hline 24 & 0,21 & 0,54 & 0,21 & 0,42 & 0,39 & 0,56 & 0,27 & 0,31 & 0,40 & 0,05 & 0,33 & 0,25 & 0,03 & 0,04 & 0,02 & 0,03 & 0,24 & 0,31 \\
\hline
\end{tabular}




\begin{tabular}{|c|c|c|c|c|c|c|c|c|c|c|c|c|c|c|c|c|c|c|}
\hline \multirow{2}{*}{ Esp. } & \multicolumn{18}{|c|}{ Threshold value d - BARREIRAS } \\
\hline & B1 & B2 & B3 & B4 & B5 & B6 & B7 & B8 & B9 & B10 & B11 & $\mathrm{B} 12$ & B13 & B14 & B15 & B16 & $\mathrm{B} 17$ & B18 \\
\hline 25 & 0,21 & 0,37 & 0,23 & 0,25 & 0,29 & 0,14 & 0,02 & 0,19 & 0,03 & 0,30 & 0,18 & 0,01 & 0,23 & 0,28 & 0,25 & 0,27 & 0,26 & 0,19 \\
\hline 26 & 0,23 & 0,12 & 0,23 & 0,26 & 0,29 & 0,30 & 0,02 & 0,06 & 0,03 & 0,30 & 0,35 & 0,43 & 0,40 & 0,23 & 0,25 & 0,03 & 0,26 & 0,31 \\
\hline 27 & 0,23 & 0,14 & 0,23 & 0,04 & 0,29 & 0,30 & 0,27 & 0,06 & 0,03 & 0,21 & 0,35 & 0,25 & 0,03 & 0,40 & 0,02 & 0,23 & 0,24 & 0,19 \\
\hline 28 & 0,06 & 0,12 & 0,62 & 0,42 & 0,57 & 0,14 & 0,02 & 0,06 & 0,03 & 0,30 & 0,33 & 0,25 & 0,40 & 0,23 & 0,25 & 0,23 & 0,24 & 0,06 \\
\hline 29 & 0,21 & 0,31 & 0,08 & 0,04 & 0,11 & 0,30 & 0,02 & 0,06 & 0,03 & 0,05 & 0,18 & 0,25 & 0,03 & 0,23 & 0,43 & 0,23 & 0,02 & 0,19 \\
\hline 30 & 0,23 & 0,14 & 0,23 & 0,26 & 0,29 & 0,30 & 0,41 & 0,19 & 0,28 & 0,38 & 0,35 & 0,25 & 0,28 & 0,23 & 0,25 & 0,23 & 0,24 & 0,37 \\
\hline 31 & 0,23 & 0,54 & 0,23 & 0,04 & 0,11 & 0,30 & 0,02 & 0,31 & 0,22 & 0,38 & 0,18 & 0,01 & 0,45 & 0,40 & 0,25 & 0,27 & 0,44 & 0,31 \\
\hline 32 & 0,23 & 0,14 & 0,08 & 0,26 & 0,11 & 0,30 & 0,23 & 0,06 & 0,03 & 0,05 & 0,18 & 0,25 & 0,03 & 0,23 & 0,25 & 0,23 & 0,02 & 0,19 \\
\hline 33 & 0,06 & 0,31 & 0,45 & 0,04 & 0,39 & 0,12 & 0,02 & 0,19 & 0,28 & 0,38 & 0,08 & 0,01 & 0,03 & 0,04 & 0,02 & 0,23 & 0,24 & 0,31 \\
\hline d Médio & 0,19 & 0,25 & 0,24 & 0,27 & 0,23 & 0,23 & 0,17 & 0,19 & 0,22 & 0,22 & 0,25 & 0,19 & 0,18 & 0,22 & 0,22 & 0,25 & 0,19 & 0,25 \\
\hline Consenso & 0,33 & 0,48 & 0,15 & 0,21 & 0,52 & 0,52 & 0,42 & 0,67 & 0,27 & 0,27 & 0,45 & 0,30 & 0,45 & 0,33 & 0,30 & 0,18 & 0,36 & 0,48 \\
\hline
\end{tabular}

\begin{tabular}{cccccccc}
\hline \multirow{2}{*}{ Esp. } & \multicolumn{7}{c}{ Threshold value d - BARREIRAS } \\
\cline { 2 - 8 } & $\mathrm{B} 19$ & $\mathrm{~B} 20$ & $\mathrm{~B} 21$ & $\mathrm{~B} 22$ & $\mathrm{~B} 23$ & $\mathrm{~B} 24$ & $\mathrm{~B} 25$ \\
\hline $\mathbf{1}$ & 0,03 & 0,10 & 0,26 & 0,10 & 0,16 & 0,09 & 0,20 \\
\hline $\mathbf{2}$ & 0,24 & 0,10 & 0,42 & 0,10 & 0,16 & 0,34 & 0,23 \\
\hline $\mathbf{3}$ & 0,24 & 0,41 & 0,26 & 0,33 & 0,34 & 0,16 & 0,20 \\
\hline $\mathbf{4}$ & 0,44 & 0,27 & 0,42 & 0,15 & 0,16 & 0,16 & 0,48 \\
\hline $\mathbf{5}$ & 0,26 & 0,10 & 0,09 & 0,35 & 0,16 & 0,34 & 0,05 \\
\hline $\mathbf{6}$ & 0,24 & 0,41 & 0,09 & 0,15 & 0,34 & 0,16 & 0,05 \\
\hline $\mathbf{7}$ & 0,26 & 0,10 & 0,09 & 0,10 & 0,34 & 0,34 & 0,20 \\
\hline $\mathbf{8}$ & 0,03 & 0,16 & 0,26 & 0,15 & 0,09 & 0,16 & 0,20 \\
\hline $\mathbf{9}$ & 0,42 & 0,27 & 0,26 & 0,10 & 0,16 & 0,34 & 0,20 \\
\hline $\mathbf{1 0}$ & 0,24 & 0,16 & 0,09 & 0,10 & 0,16 & 0,34 & 0,20 \\
\hline $\mathbf{1 1}$ & 0,03 & 0,10 & 0,09 & 0,15 & 0,16 & 0,34 & 0,05 \\
\hline
\end{tabular}




\begin{tabular}{|c|c|c|c|c|c|c|c|}
\hline \multirow{2}{*}{ Esp. } & \multicolumn{7}{|c|}{ Threshold value d - BARREIRAS } \\
\hline & B19 & B20 & B21 & B22 & B23 & B24 & B25 \\
\hline 12 & 0,42 & 0,10 & 0,17 & 0,33 & 0,16 & 0,34 & 0,23 \\
\hline 13 & 0,44 & 0,27 & 0,17 & 0,35 & 0,16 & 0,09 & 0,05 \\
\hline 14 & 0,44 & 0,27 & 0,17 & 0,15 & 0,16 & 0,34 & 0,20 \\
\hline 15 & 0,26 & 0,10 & 0,09 & 0,10 & 0,16 & 0,34 & 0,05 \\
\hline 16 & 0,03 & 0,41 & 0,09 & 0,10 & 0,09 & 0,16 & 0,05 \\
\hline 17 & 0,03 & 0,16 & 0,17 & 0,15 & 0,09 & 0,09 & 0,05 \\
\hline 18 & 0,44 & 0,27 & 0,17 & 0,35 & 0,16 & 0,09 & 0,05 \\
\hline 19 & 0,24 & 0,41 & 0,26 & 0,33 & 0,52 & 0,34 & 0,20 \\
\hline 20 & 0,24 & 0,16 & 0,09 & 0,10 & 0,09 & 0,09 & 0,05 \\
\hline 21 & 0,03 & 0,27 & 0,09 & 0,15 & 0,34 & 0,34 & 0,05 \\
\hline 22 & 0,26 & 0,10 & 0,42 & 0,35 & 0,16 & 0,34 & 0,05 \\
\hline 23 & 0,26 & 0,16 & 0,09 & 0,10 & 0,16 & 0,34 & 0,23 \\
\hline 24 & 0,26 & 0,27 & 0,26 & 0,15 & 0,09 & 0,34 & 0,05 \\
\hline 25 & 0,03 & 0,10 & 0,26 & 0,10 & 0,09 & 0,16 & 0,20 \\
\hline 26 & 0,03 & 0,27 & 0,17 & 0,10 & 0,16 & 0,09 & 0,20 \\
\hline 27 & 0,24 & 0,16 & 0,09 & 0,33 & 0,34 & 0,16 & 0,23 \\
\hline 28 & 0,26 & 0,10 & 0,42 & 0,35 & 0,16 & 0,34 & 0,48 \\
\hline 29 & 0,03 & 0,16 & 0,09 & 0,10 & 0,34 & 0,09 & 0,05 \\
\hline 30 & 0,24 & 0,41 & 0,26 & 0,15 & 0,09 & 0,16 & 0,20 \\
\hline 31 & 0,42 & 0,27 & 0,09 & 0,15 & 0,09 & 0,09 & 0,65 \\
\hline 32 & 0,03 & 0,16 & 0,09 & 0,10 & 0,09 & 0,09 & 0,20 \\
\hline 33 & 0,42 & 0,10 & 0,42 & 0,33 & 0,16 & 0,09 & 0,05 \\
\hline d Médio & 0,23 & 0,21 & 0,19 & 0,19 & 0,18 & 0,22 & 0,17 \\
\hline Consenso & 0,30 & 0,58 & 0,61 & 0,70 & 0,79 & 0,55 & 0,42 \\
\hline
\end{tabular}




\begin{tabular}{|c|c|c|c|c|c|c|c|c|c|c|c|c|c|c|c|c|c|c|c|}
\hline \multirow{2}{*}{ Esp. } & \multicolumn{18}{|c|}{ Threshold value d - FATORES CRÍTICOS DE SUCESSO } & \multirow[b]{2}{*}{$\mathrm{FC} 19$} \\
\hline & FC1 & $\mathrm{FC2}$ & FC3 & FC4 & FC5 & FC6 & FC7 & FC8 & FC9 & FC10 & FC11 & $\mathrm{FC} 12$ & $\mathrm{FC} 13$ & $\mathrm{FC} 14$ & $\mathrm{FC} 15$ & $\mathrm{FC} 16$ & $\mathrm{FC} 17$ & $\mathrm{FC} 18$ & \\
\hline 1 & 0,04 & 0,15 & 0,04 & 0,09 & 0,04 & 0,22 & 0,05 & 0,08 & 0,07 & 0,12 & 0,26 & 0,21 & 0,12 & 0,08 & 0,11 & 0,08 & 0,06 & 0,24 & 0,10 \\
\hline 2 & 0,17 & 0,15 & 0,04 & 0,17 & 0,19 & 0,22 & 0,23 & 0,14 & 0,25 & 0,30 & 0,26 & 0,21 & 0,09 & 0,12 & 0,11 & 0,13 & 0,23 & 0,07 & 0,10 \\
\hline 3 & 0,04 & 0,05 & 0,04 & 0,09 & 0,19 & 0,22 & 0,05 & 0,08 & 0,07 & 0,12 & 0,26 & 0,21 & 0,12 & 0,08 & 0,09 & 0,08 & 0,06 & 0,24 & 0,15 \\
\hline 4 & 0,17 & 0,05 & 0,17 & 0,09 & 0,04 & 0,46 & 0,21 & 0,14 & 0,25 & 0,12 & 0,08 & 0,05 & 0,09 & 0,08 & 0,09 & 0,13 & 0,06 & 0,20 & 0,10 \\
\hline 5 & 0,04 & 0,05 & 0,17 & 0,17 & 0,04 & 0,05 & 0,21 & 0,14 & 0,18 & 0,13 & 0,18 & 0,23 & 0,32 & 0,08 & 0,09 & 0,13 & 0,20 & 0,20 & 0,15 \\
\hline 6 & 0,04 & 0,05 & 0,17 & 0,09 & 0,19 & 0,22 & 0,23 & 0,14 & 0,07 & 0,30 & 0,08 & 0,21 & 0,12 & 0,12 & 0,11 & 0,13 & 0,06 & 0,07 & 0,10 \\
\hline 7 & 0,04 & 0,05 & 0,04 & 0,17 & 0,19 & 0,05 & 0,21 & 0,08 & 0,18 & 0,12 & 0,08 & 0,05 & 0,12 & 0,12 & 0,11 & 0,08 & 0,06 & 0,07 & 0,15 \\
\hline 8 & 0,04 & 0,05 & 0,17 & 0,09 & 0,19 & 0,05 & 0,23 & 0,14 & 0,25 & 0,30 & 0,26 & 0,21 & 0,12 & 0,12 & 0,09 & 0,13 & 0,06 & 0,24 & 0,10 \\
\hline 9 & 0,04 & 0,05 & 0,04 & 0,17 & 0,19 & 0,05 & 0,21 & 0,08 & 0,07 & 0,12 & 0,26 & 0,21 & 0,12 & 0,08 & 0,11 & 0,13 & 0,20 & 0,24 & 0,10 \\
\hline 10 & 0,04 & 0,15 & 0,04 & 0,27 & 0,25 & 0,22 & 0,05 & 0,14 & 0,18 & 0,12 & 0,08 & 0,21 & 0,09 & 0,12 & 0,11 & 0,31 & 0,20 & 0,20 & 0,15 \\
\hline 11 & 0,17 & 0,05 & 0,27 & 0,09 & 0,25 & 0,22 & 0,05 & 0,14 & 0,18 & 0,38 & 0,18 & 0,23 & 0,12 & 0,08 & 0,09 & 0,13 & 0,06 & 0,20 & 0,10 \\
\hline 12 & 0,04 & 0,05 & 0,04 & 0,09 & 0,25 & 0,22 & 0,05 & 0,14 & 0,07 & 0,13 & 0,18 & 0,05 & 0,09 & 0,08 & 0,09 & 0,08 & 0,06 & 0,07 & 0,10 \\
\hline 13 & 0,04 & 0,05 & 0,17 & 0,09 & 0,19 & 0,64 & 0,21 & 0,08 & 0,18 & 0,13 & 0,18 & 0,23 & 0,09 & 0,08 & 0,09 & 0,31 & 0,20 & 0,20 & 0,15 \\
\hline 14 & 0,04 & 0,05 & 0,04 & 0,09 & 0,04 & 0,22 & 0,21 & 0,14 & 0,43 & 0,13 & 0,08 & 0,05 & 0,12 & 0,08 & 0,11 & 0,31 & 0,20 & 0,07 & 0,15 \\
\hline 15 & 0,04 & 0,05 & 0,17 & 0,27 & 0,19 & 0,05 & 0,05 & 0,14 & 0,07 & 0,12 & 0,08 & 0,05 & 0,09 & 0,08 & 0,11 & 0,13 & 0,23 & 0,24 & 0,29 \\
\hline 16 & 0,04 & 0,05 & 0,04 & 0,27 & 0,04 & 0,05 & 0,23 & 0,14 & 0,25 & 0,30 & 0,08 & 0,05 & 0,12 & 0,12 & 0,09 & 0,08 & 0,06 & 0,24 & 0,10 \\
\hline 17 & 0,04 & 0,15 & 0,27 & 0,09 & 0,04 & 0,05 & 0,23 & 0,54 & 0,07 & 0,13 & 0,18 & 0,23 & 0,09 & 0,08 & 0,11 & 0,13 & 0,23 & 0,07 & 0,10 \\
\hline 18 & 0,04 & 0,05 & 0,17 & 0,27 & 0,19 & 0,22 & 0,05 & 0,08 & 0,18 & 0,13 & 0,08 & 0,05 & 0,12 & 0,08 & 0,11 & 0,13 & 0,06 & 0,24 & 0,15 \\
\hline 19 & 0,04 & 0,05 & 0,17 & 0,27 & 0,19 & 0,22 & 0,23 & 0,14 & 0,25 & 0,30 & 0,26 & 0,21 & 0,12 & 0,12 & 0,11 & 0,13 & 0,23 & 0,24 & 0,29 \\
\hline 20 & 0,04 & 0,05 & 0,04 & 0,09 & 0,04 & 0,22 & 0,05 & 0,14 & 0,07 & 0,13 & 0,08 & 0,05 & 0,09 & 0,12 & 0,11 & 0,08 & 0,23 & 0,24 & 0,10 \\
\hline 21 & 0,04 & 0,05 & 0,04 & 0,17 & 0,19 & 0,05 & 0,23 & 0,14 & 0,07 & 0,12 & 0,08 & 0,05 & 0,09 & 0,12 & 0,11 & 0,13 & 0,20 & 0,20 & 0,15 \\
\hline 22 & 0,17 & 0,15 & 0,27 & 0,42 & 0,49 & 0,05 & 0,46 & 0,30 & 0,43 & 0,38 & 0,08 & 0,47 & 0,56 & 0,08 & 0,33 & 0,31 & 0,45 & 0,07 & 0,40 \\
\hline 23 & 0,17 & 0,05 & 0,04 & 0,17 & 0,19 & 0,22 & 0,05 & 0,14 & 0,07 & 0,30 & 0,08 & 0,21 & 0,09 & 0,08 & 0,09 & 0,13 & 0,23 & 0,07 & 0,15 \\
\hline 24 & 0,04 & 0,15 & 0,04 & 0,17 & 0,25 & 0,05 & 0,05 & 0,14 & 0,07 & 0,12 & 0,18 & 0,05 & 0,09 & 0,32 & 0,09 & 0,08 & 0,20 & 0,45 & 0,15 \\
\hline 25 & 0,04 & 0,05 & 0,04 & 0,17 & 0,25 & 0,22 & 0,21 & 0,30 & 0,18 & 0,38 & 0,18 & 0,05 & 0,09 & 0,12 & 0,11 & 0,31 & 0,20 & 0,20 & 0,10 \\
\hline
\end{tabular}




\begin{tabular}{|c|c|c|c|c|c|c|c|c|c|c|c|c|c|c|c|c|c|c|c|}
\hline \multirow{2}{*}{ Esp. } & \multicolumn{18}{|c|}{ Threshold value d - FATORES CRÍTICOS DE SUCESSO } & \multirow[b]{2}{*}{$\mathrm{FC} 19$} \\
\hline & $\mathrm{FC} 1$ & FC2 & FC3 & FC4 & FC5 & FC6 & FC7 & FC8 & FC9 & FC10 & FC11 & $\mathrm{FC} 12$ & $\mathrm{FC} 13$ & FC14 & FC15 & FC16 & FC17 & FC18 & \\
\hline 26 & 0,04 & 0,05 & 0,17 & 0,42 & 0,04 & 0,05 & 0,05 & 0,30 & 0,25 & 0,38 & 0,42 & 0,47 & 0,12 & 0,08 & 0,33 & 0,13 & 0,45 & 0,45 & 0,40 \\
\hline 27 & 0,04 & 0,05 & 0,04 & 0,27 & 0,04 & 0,05 & 0,05 & 0,08 & 0,18 & 0,12 & 0,08 & 0,21 & 0,12 & 0,08 & 0,09 & 0,08 & 0,06 & 0,07 & 0,15 \\
\hline 28 & 0,04 & 0,15 & 0,04 & 0,17 & 0,04 & 0,46 & 0,21 & 0,08 & 0,07 & 0,13 & 0,18 & 0,23 & 0,32 & 0,08 & 0,09 & 0,08 & 0,06 & 0,07 & 0,10 \\
\hline 29 & 0,17 & 0,15 & 0,27 & 0,09 & 0,25 & 0,22 & 0,05 & 0,14 & 0,18 & 0,12 & 0,08 & 0,05 & 0,12 & 0,12 & 0,09 & 0,13 & 0,23 & 0,20 & 0,10 \\
\hline 30 & 0,04 & 0,05 & 0,17 & 0,09 & 0,04 & 0,05 & 0,21 & 0,14 & 0,07 & 0,12 & 0,18 & 0,23 & 0,12 & 0,12 & 0,11 & 0,08 & 0,23 & 0,24 & 0,10 \\
\hline 31 & 0,04 & 0,05 & 0,27 & 0,17 & 0,04 & 0,22 & 0,05 & 0,71 & 0,07 & 0,38 & 0,42 & 0,21 & 0,12 & 0,12 & 0,11 & 0,13 & 0,06 & 0,62 & 0,10 \\
\hline 32 & 0,04 & 0,05 & 0,17 & 0,17 & 0,25 & 0,05 & 0,23 & 0,08 & 0,18 & 0,13 & 0,08 & 0,23 & 0,12 & 0,08 & 0,11 & 0,13 & 0,06 & 0,07 & 0,10 \\
\hline 33 & 0,04 & 0,05 & 0,04 & 0,09 & 0,04 & 0,05 & 0,05 & 0,14 & 0,25 & 0,13 & 0,18 & 0,05 & 0,12 & 0,12 & 0,09 & 0,13 & 0,06 & 0,24 & 0,29 \\
\hline d Médio & 0,06 & 0,07 & 0,12 & 0,17 & 0,15 & 0,17 & 0,15 & 0,17 & 0,17 & 0,20 & 0,16 & 0,17 & 0,13 & 0,11 & 0,12 & 0,14 & 0,16 & 0,20 & 0,15 \\
\hline Consenso & 1,00 & 1,00 & 0,85 & 0,76 & 0,76 & 0,45 & 0,45 & 0,85 & 0,73 & 0,67 & 0,76 & 0,39 & 0,91 & 0,97 & 0,94 & 0,85 & 0,45 & 0,58 & 0,85 \\
\hline
\end{tabular}

